МОСКОВСКИЙ ГОСУДАРСТВЕННЫЙ УНИВЕРСИТЕТ имени М. В. ЛОМОНОСОВА

ФИЛОЛОГИЧЕСКИЙ ФАКУЛЬТЕТ

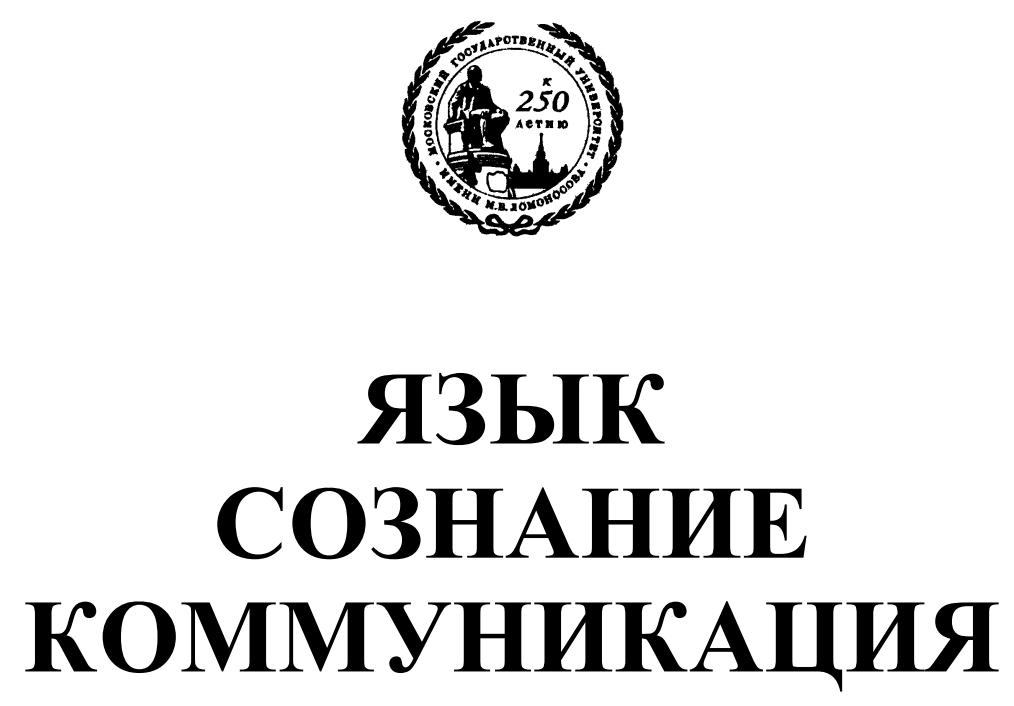

Выпуск 26

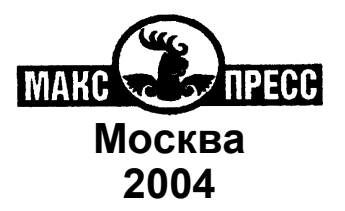


ББК 81

9410

К 250-летию МГУ имени М.В. Ломоносова

\author{
Печатается по постановлению \\ Редакиионно-издательского совета \\ филологического факультета МГУ имени М. В. Ломоносова
}

Рецензенты:

д.п.н., проф. Ю.Е. Прохоров

д.ф.н., проф. Ю.А. Сорокин

Электронные версии (.pdf) всех опубликованных выпусков доступны на

http://www.philol.msu.ru/ slavphil/books/jsk_index.html

Представляя рукопись в редколлегию, авторы тем самым выражают согласие с её безгонорарным опубликованием в сборнике "Язык, сознание, коммуникация" в печатном и/или электронном виде, включая размещение в Интернете

Язык, сознание, коммуникация: Сб. статей / Отв. ред. Я410 В. В.Красных, А.И. Изотов. - М.: МАКС Пресс, 2004. Вып. 26. - 168 с.

\title{
ISBN 5-317-00981-2
}

Сборник содержит статьи, рассматривающие различные проблемы коммуникации как в свете лингвокогнитивного подхода, так и в сопоставительном аспекте, а также наиболее актуальные проблемы лингводидактики. Особое внимание уделяется национальной специфике общения, проявляющейся в особенностях ассоциативных рядов, коннотативного потенциала и восприятия художественных текстов.

Сборник предназначается для филологов - студентов, преподавателей, научных сотрудников.

Выпуски 1 и 2 опубликованы в 1997 г., выпуски 3, 4, 5, 6 в 1998 г., выпуски 7, 8, 9, 10 - в 1999 г., выпуски 11, 12, 13, 14, 15 в 2000 г., выпуски 16, 17, 18, 19, 20 - в 2001 г., выпуски 21, 22 в 2002 г., выпуски 23, 24, 25 - в 2003 г.

ББК 81

Я410

ISBN 5-317-00981-2

(C) Авторы статей, 2004 


\section{СОДЕРЖАНИЕ}

\section{ЯЗЫК И ОБЩЕСТВО}

Якоб Фрухтманн. К проблеме анализа крупных массивов текстов - применение прикладного анализа политического дискурса ..................5

Темнова Е. В. Современные подходы к изучению дискурса ...................24

Никипорец-Такигава Г. Ю. Языковая норма в постсоветской

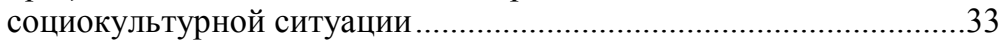

Гудков Д. Б. Единицы кодов культуры: проблемы семантики ................39

Филимонова Е. Н. Символика животных в переводных произведениях. «Священные» животные (на материале переводов с корейского и китайского языков).

Полиниченко Д. Ю. Концепт «язык» в английской паремиологии ...........83

Привалова И. В. К определению понятия «языковые маркеры национально-культурного сознания»

Кальгин А.И. Философия поступка М. Бахтина как феноменология необязательного действия

ЛИНГВИСТИКА

Виноградова Е. Н., Чекалина В. Л. Русские предложные единицы (предлоги и их эквиваленты). Синонимия и антонимия ...

Антонова И.А. О терминах «категория состояния» и «предикативы». Предикативы как предикат для выражения эмоционального состояния/отношения

Гарагуля С.И. К проблеме категоризации английского личного имени

Дамаданова П.А. Отраслевая и языковая специфика терминов немецкого гражданского права.

Жамбалова И.Б. Семантические особенности существительного Geist в современном немецком языке

Магомедова П.У. Сложные слова с основой существительного Leben в современном немецком языке. 


\section{ЛИНГВОПОЭТИКА}

Торопова Т.Ю. «Жизнь и смерть в текстах Андрея Платонова» («Котлован», «Сокровенный человек», «Усомнившийся Макар», «Дневник»). Работа по восприятию текста с использованием приема «смысловой ход конем» 


\title{
ЯЗЫК И ОБЩЕСТВО
}

\section{К проблеме анализа крупных массивов текстов - применение прикладного анализа политического дискурса}

\author{
(C) Dr rer. pol. Якоб Фрухтманн, 2004
}

\section{Резюме}

Предлагаемый семасиологический метод анализа призван выявить значение политического дискурса, исходя из его речевого выражения. Целью анализа является получение методологически обоснованных данных о значении политического дискурса, т. е. о концепциях политических актеров, которые он передает.

Значения дискурса (концепции) состоят из структурных элементов дискурса и их отношений друг к другу. Следовательно, чтобы выявить концепции, скрывающиеся за политическим дискурсом, необходимо выявить элементы дискурса и их внутренние связи.

С точки зрения лингвистики здесь необходимо решить проблему изучения большого количества текстов. Мы предлагаем сократить общее количество релевантных текстов до упорядоченного корпуса наиболее содержательных высказываний, который затем может быть разобран средствами анализа текста. В центре такого анализа стоит выявление дискурсивной когерентности. В результате будут раскрыты основополагающие категории политического дискурса, а также их разные аспекты и элементы.

Таким образом, метод позволяет выявить систематические соотношения между высказываниями представителей конкурирующих точек зрения.

\section{Введение}

Факты и действия, которых касаются политические дискурсы, можно разделить на (предшествующие дискурсу, заданные) предпосылки и (следующие за дискурсом или одновременные с ним) политические мероприятия. Как правило, это неудовлетворенность политического актера (группы актеров) ситуацией, неудовлетворенность «данностью», что дает актеру повод заново развить дискурс и таким образом ввести новые действия, целью которых является изменение сложившейся ситуации. При этом политическая борьба за гегемонию в дискурсе играет важнейшую роль ${ }^{1}$.

${ }^{1}$ Дискурсивная гегемония присутствует в политическом дискурсе в том случае, если условием участия актера в дискурсе служит негласное или эксплицитное принятие им определенных основополагающих категорий дискурса (см. ниже). Дискурсивная гегемония не означает, что существуют только однородные и однонаправленные высказыва- 
Поэтому прикладной анализ политического дискурса претендует не только на «изолированное» изучение отдельных высказываний политических актеров, но и требует соединения этого анализа с ситуативным, акциональным и дискурсивным контекстами высказываний. При этом необходимо показать:

а) какие факты воспринимаются в политических концепциях актеров как побуждение к действию;

б) как соотносятся акциональный и вербальный контексты их политики, и насколько они соответствуют друг другу (насколько, так сказать, «слово» соответствует «делу»);

в) как пострадавшие от действий группы актеров-инициаторов реагируют на их дискурсивную атаку и в связи с этим

г) как и в какой степени актеры-инициаторы завоюют дискурсивную гегемонию над общественностью; и наконец,

д) появляются ли в результате новые, измененные, политические реалии.

Таким образом, прикладной анализ политического дискурса практически соответствует в области политики требованиям «анализа диспозитива» ${ }^{2}$.

Аспекты анализа политического дискурса не могут быть представлены здесь во всей полноте ${ }^{3}$. Предметом настоящей статьи является методологическое решение частной проблемы, которая появляется при использовании данного метода и имеет лингвистическую природу: как могут быть выявлены методологически точно и убедительно политические концепции одного или группы политических актеров на материале большого количества политических высказываний? Выяснение политических концепций в любом случае требует изучения политического языка. Поэтому понятно использование лингвистических методов ${ }^{4}$.

ния. Но она ставит перед актерами вопрос, как при таких условиях можно вписать в дискурс их различающиеся интересы. Понятие гегемонии восходит к Грамши, сp. Gramsci 1983. О понятии дискурсивной гегемонии см. также Laclau/Mouffe 1995.

2 Диспозитив (франц. dispositíf) - совокупность дискурса и его акционального и ситуационального контекстов. Йегер, опираясь на Фуко, так определяет диспозитив: «Так как знание является основой действий (и речевых действий в том числе - Я.Ф.) и оформлением действительности, напрашивается анализировать не только дискурсивные практики, но и недискурсивные и так называемые очевидности/наглядности, а также их взаимоотношения. Это взаимодействие я вместе с Фуко называю диспозитивом» (Jäger 2001b:93). Подобный анализ Йегер называет анализом диспозитива. Однако на сегодня необходимая методика еще не разработана подробно. Предлагаемый нами прикладной анализ политического дискурса можно рассматривать как применение такого анализа диспозитива.

${ }^{3}$ Настоящая статья охватывает часть исследования, в котором средствами прикладного анализа политического дискурса исследовался современный российский дискурс о федерализме. Полный вариант см. в Fruchtmann 2003. Приводимые здесь конкретные примеры основаны на этой работе.

${ }^{4}$ Политологические анализы часто бывают ориентированы на анализ языка, ср. например Windhoff-Héritier 1987 или Hartwich 1985. Одновременно в лингвистике предпри6 


\section{Предмет и цель анализа политического дискурса}

На вербальном уровне высказывания политические дискурсы представляют собой только ограниченное лингвистическими и, в первую очередь, внелингвистическими параметрами языковое единство, множество текстов: Политические дискурсы - это виртуальные тематически взаимосвязанные и/или имеющие взаимные отсылки корпусы вербального общения политических актеров, касающегося политической реальности и действий 5 .

Значение политического дискурса позволяет понять политическое отношение говорящих к политическим реалиям и действиям, их политические концепции. Под политическими концепциями политических актеров мы понимаем совокупность их восприятий, связанных с политической реальностью и лежащих в основе политических действий, их целевых установок и (стратегических) подходов, которые можно выявить из их высказываний.

Задача анализа состоит в осмысленном применении лингвистических методов для выявления концепции определенных политических актеров или их групп по определенной теме (области политики) на материале большого количества текстов, в которых она выражена.

Аналогично методу анализа текста, представленному в 80-е годы, например, ван Дейком, наш анализ концепций должен, в первую очередь, выявить макроструктуру подобного дискурса ${ }^{6}$. Однако за этим следует методологическая трудность: как можно рационально сопоставить, обобщить и семантически-понятийно исследовать большое количество текстов? В лингвистике текста уже разработаны методики сопоставления отдельных текстов. Но как можно провести подобный анализ, если переступаются границы текстового единства?

Предлагаемое здесь решение основывается на переносе «принципа Фреге» на дискурсы, а следовательно, и политические дискурсы. Со-

нимаются инициативы в области теории дискурса, которые сейчас играют важную роль и в анализе текстов и дискурсов. Компактный и довольно полный обзор различных методов анализа текста и дискурса можно найти в книге Titscher/Meyer/Wodak/Vetter 2000.

5 Доступны для исследования эти корпусы только в виде собрания конкретных текстов, т. е. только как корпус для анализа. Это знаковое определение дискурса опирается на общее определение дискурсов, предложенное Буссе и Тойбертом, как «виртуальных тематически взаимосвязанных и/или имеющих взаимные отсылки корпусов». Busse/Teubert 1992:4. Понятие «дискурс» явно многозначно. Краткий обзор различных значений см. в: Рассошенко 2003.

${ }^{6}$ Макроструктуры дают семантическое представление о глобальной связи и значении текстов, находящееся на более высоком уровне в качестве значения единственной пропозиции. То есть большое количество пропозиций может образовать единицу значения на глобальном уровне. Согласно ван Дайку, любая макроструктура должна отвечать тем же требованиям семантической коннексии, что и микроструктура, т. е., к примеру, связывать пропозиции условно или причинно (cp. van Dijk 1980:42 и след.). 
гласно этому принципу, значение сложного высказывания рассматривается как функция от значений его частей и способа их соединения, т.е. их структурного соотношения ${ }^{7}$. Политические дискурсы, также как и сложные слова, предложения и тексты, являются комплексными высказываниями, языковыми единствами, а значит, они тоже должны подчиняться принципу Фреге, как и остальные комплексные высказывания.

Таким образом, исходным пунктом метода служит выявление концепций, лежащих в основе дискурса с помощью выявления его элементов и структур. Если мы сможем свести некий дискурс до его важнейших элементов и реконструировать их структурные взаимоотношения, то мы выясним и его значение, политические концепции, которые он содержит.

Основная идея практического применения метода состоит в том, что некое множество текстов, относительно герметично выражающих определенную концепцию, в принципе может быть сведено к одному единственному тексту, содержащему все важнейшие семантические элементы всего корпуса.

Для этого надо составить список цитат, который бы содержал все части концепции в гораздо меньшем объеме. Этот «дистиллят» должен отвечать требованию содержания всех важных компонентов концепции определенной личности по определенной теме в наиболее краткой форме.

После составления такого корпуса следует анализировать когеренции (англ. coherence, нем. Kohärenz) корпуса, т. е. из «продистиллированного» материала необходимо выявить взаимоотношения его элементов и таким образом общую концепцию по исследуемой теме ${ }^{8}$.

Прежде чем обратиться к подробному обсуждению этих шагов, следует оговорить сразу возникающие возражения: имеет ли смысл выяснять политические концепции, сводя речи политиков к небольшому количеству цитат и затем подробно их исследуя? Не воспринимаются ли при этом высказывания политиков слишком серьезно, нет ли риска впасть в мелочное буквоедство?

Тексты, конституирующие политические дискурсы, отличаются, как правило, высокой степенью публичности и фиксированности темы, а также языкового планирования. Таким образом, они даже в устной форме составляют противоположность обычному «устному языку».9

\footnotetext{
${ }^{7}$ Бартч и Веннеманн формулируют этот принцип так, что «интерпретация высказывания является функцией интерпретаций его частей» (Bartsch/Vennemann 1980:66)

8 Для большей ясности эти два шага будут здесь рассмотрены по отдельности, на практике же они постоянно переплетаются.

${ }_{9}^{9}$ Устный язык в целом характеризуется низкой степенью языкового планирования и вербализации. Это обусловлено диалогическим характером, ситуативной близостью, 8
} 
Любое политическое речевое действие, любой дискурсивный акт политических актеров, будучи даже незапланированным и промежуточным, рассматривается политическими противниками как запланированный. Поэтому любой политический дискурсивный акт считается в очень большой степени запланированным - не важно, «субъективно» это в каждом случае или нет. Конечно, любой политический актер знает об этой особенности политического языка, когда принимает участие в политической коммуникации. Эту особенность следует понимать как «правило образования» (в смысле Фуко) политических высказываний. Поэтому политические высказывания авторитетных актеров, акты политического дискурса, могут быть проанализированы гораздо точнее, «дословнее», чем другие высказывания.

Второе возражение, которое следует оговорить, состоит в следующем: не может ли такой подход вести к аналитическому произволу? Ведь, суть анализа состоит в процессах деконструкции и целесообразной реконструкиии дискурса. Найденные цитаты при этом сознательно вырываются из их контекста, насколько это допустимо без искажения их смысла. Но возникающий при таком подходе эффект отчуждения не следует поэтому рассматривать как аналитический «регресс».

Чтобы выполнять свои функции, политический язык, во-первых, совершенно целенаправленно пользуется общепринятыми, политисторическими и социокультурными «данностями». При этом получается, что многое в политике остается высказанным лишь имплицитно ${ }^{10}$. Также важна высокая степень неопределенности высказываний, которая тоже позволяет многим согласиться с автором, несмотря, или как раз потому, что его политическая концепция выражена не совсем определенно и ясно ${ }^{11}$. Но, несмотря на эту «популистскую туманность» политического языка, политик при этом вынужден одновременно транспортировать идеи, которые можно идентифицировать именно с ним (или его партией) и (что еще важнее) с его политикой, таким образом отличаясь от своих конкурентов. Поэтому, в политическом языке доминирует «транспортируемое - но не высказанное».

Эти особенности политического языка не только наводят на мысль о применении лингвистических методов, но и обосновывают метод деконструкции политического дискурса с открывающейся затем воз-

непостоянством высказываний и тем обстоятельством, что языковое выражение не является единственным носителем информации.

${ }^{10}$ Например, Эдельман говорит: «Политик может более убедительно нарисовать картину реальности, если он имплицитно вводит ее в свою манеру речи, а не высказывает открыто» (Edelman 1980:41).

11 Дикманн подчеркивает неопределенность политических понятий. Он исходит из их абстрактности, сложности, нечеткости, относительности, многозначности и говорит об идеологической полисемии. Сp. Dieckmann 1980. 
можностью его реконструкции. Таким образом можно «разогнать языковой туман» и эксплицировать «транспортируемые - но не высказанные» политические концепции. Цитаты при этом и теряют свою риторическую «защиту» окружающего их текста и позволяют увидеть элементы значения как таковые.

Особенно важны при этом высказывания актеров, кажущиеся на первый взгляд нелогичными. Они дают деконструкции точку опоры, зацепку для взлома исходного корпуса. Часто бывает, что кажущиеся или действительные противоречия и бессмыслицы получают смысл только в реконструированной зависимости.

Итоговый реконструкт, как правило, «логичнее», чем отдельные высказывания сами по себе, теперь его впрямую организуют мотивирующие текст концептуальные связи. Не исключено также, что в результате анализа не выявится никаких структурных взаимосвязей или только незначительные. Это будет свидетельствовать о том, что нет и политической концепции.

Ниже будет сначала подробнее освещен процесс выявления элементов дискурса, а затем мы более детально опишем анализ его внутренних взаимосвязей.

\section{Составление корпуса для анализа.}

Целью данного этапа является воспроизведение структуры дискурса с помощью цитат из оригинала. Средствами для этого являются: a) поиск соответствующих текстов, б) сокращение их до отрывков текста, важных для постановки вопроса и в) их упорядочение. Эти шаги должны в процессе анализа постоянно повторяться заново. Средством для этого служит первичный анализ (упорядочение, сокращение, новый поиск недостающих частей, последующее распределение отдельных цитат). При этом образ действия похож на тот, который ван Дейк с помощью понятия «макроправила» предлагает для анализа текстов ${ }^{12}$.

а) Сначала целью является нахождение всех текстов, важных для выявления концепции определенного лица или группы лиц по определенной теме. Итогом этого этапа является корпус для предварительного анализа. Как можно понять из приведенного выше определения политического дискурса, первым критерием сопоставления текстов является их тематическая принадлежность. Однако на деле разграничение дискурсов происходит с помощью целого ряда внелингвистических парамет-

12 Согласно ван Дейку, макроправила позволяют выявить макроструктуры. Он причисляет к ним следующие правила: пропуск, селекция, генерализация и конструкция. Макроправила делают возможным методически обоснованное разделение главного и второстепенного при обобщении текстов (cp. van Dijk 1980:49 и след.). Здесь похожие правила служат для составления корпуса для анализа.

10 
ров. При ограничивающем применении этих параметров определяется объем текстов, входящих в «виртуальный корпус» дискурса. К ним можно отнести ${ }^{13}$ :

* параметры, связанные со спецификой говорящего - это могут быть как политические, так и группы по интересам, а также отдельные актеры).

* временные параметры - ограничение временных рамок исследования должно находиться в разумной связи с темой и с интертекстуальными связями текста.

* медиальные параметры источника информации - исследование может быть ограничено только публикациями в интернете, выпусками новостей разных телекомпаний и т.д. (при этом могут быть исследованы также и дискурсивные особенности источника).

Выбор анализируемых актеров и временных рамок подвергается постоянному пересмотру в процессе работы, т.е. служит одновременно и результатом, и предпосылкой для дальнейшего анализа. Ведь выбор наиболее подходящего для исследования круга лиц и временного промежутка всегда зависит от данных, уже выявленных в результате анализа материала. Так, например, может оказаться, что после определенного периода времени больше не появляется релевантных высказываний или что следует привлечь к исследованию дополнительных актеров.

Из всего объема текстов выделяются отдельные точки зрения или тексты о тех событиях, которые можно назвать «дискурсивными событиями». Они связывают дискурс с его историей и процессом его изменения. В качестве примера подобного дискурсивного события Йегер называет события в Чернобыле в 80-е годы прошлого века (Jäger 2001a: 47). Веллер в своей статье о построении сообщений немецких СМИ в первые часы после терактов 11.09.2001 называет атаку на ВТЦ в НьюЙорке дискурсивным событием (Weller 2002). Однако далеко не всегда дискурсивные события должны иметь такой драматичный характер. Так в отношении дискурса о российском федерализме как дискурсивное событие может быть интерпретировано телевизионное обращение президента Путина зимой 2000 года. Оно представляет собой поворотный пункт российской дискуссии о федерализме ${ }^{14}$. Этот пример хорошо показывает, что дискурсивное событие совсем не обязательно происходит из внеязыковой среды.

\footnotetext{
13 Это представление базируется на идее «дискурсивного куба» Юнга, который, однако, в качестве аспектов дискурса называет области общения, виды текста и частные дискурсы. Cp. Jung 1996.

${ }^{4}$ Путин 2000а. Это обращение нашло отклик у широкой общественности, ему уделили много внимания в выпусках новостей на ОРТ и НТВ, а также в большинстве ежедневных газет, большое количество политических комментариев прямо его касалось.
} 
Формально, насколько позволяют технические средства, дискурсивные события можно выделить по относительной частоте использования определенных слов, связанных с темой, в рассматриваемый период в $\mathrm{CM}^{15}$. Например, в первом случае это могут быть слова «Чернобыль», «АЭС» и др.

В отличие от приведенных сравнительно «безличных» примеров при определенных темах выбор круга исследуемых лиц может приобретать большое значение. В случае современного российского дискурса о федерализме в центре внимания оказываются высказывания российского президента - он является актером-инициатором, стремился к изменению федеральной структуры страны и в первую очередь включился в господствовавший тогда дискурс о федерализме. В качестве временного периода для исследования наиболее подходящий отрезок - первые два года президентства Путина, ведь в это время могли быть введены решающие новшества в рассматриваемой области.

При поиске могут и должны быть по максимуму использованы возможности интернета и компьютерной поддержки исследования. Следует использовать все возможные способы систематического поиска, его ограничения и расширения и т. д.

При этом наибольшее значение после комбинации имен исследуемых актеров/групп актеров и исследуемой темы имеют соответствующие политические ключевые слова ${ }^{16}$. Здесь важен критерий повторяемости. Наиболее часто встречающиеся формулировки, метафоры и т. п. свидетельствуют о том, что говорящий придает особое значение передаче выраженной мысли, что здесь убеждение публики особенно важно для него. Следовательно, корпус для анализа должен содержать именно такие повторяющиеся фигуры. Если эти ключевые слова нам уже известны, можно здесь это знание применить. При чтении найденных отрывков мы найдем и другие искомые слова, которые могут оказаться релевантными политическими ключевыми словами, такими как в примере с российским дискурсом о федерализме «вертикаль власти» или

${ }^{15}$ В случае с российским политическим дискурсом большие возможности частотной организации материала по четко ограниченным промежуткам времени дают такие базы данных, как, например, «Интегрум», которая предлагает также онлайновый частотный словарь. Эти временные промежутки также помогают при дальнейшем поиске как ограничивающий или уточняющий фактор для временных параметров исследуемого дискурса.

${ }^{16}$ Политическое ключевое слово - это нацеленное на общественное воздействие, часто зависимое от идеологии и оценочное выражение, с которым связываются политические концепции. Cp. Knobloch 1998. В качестве актуальных примеров для Германии лингвистический словарь Метцлер приводит следующие: «Bündnis für Arbeit» («союз за работу», в связи с сокращением социальных трансфертов и снижением уровня зарплат) или «Luftschlag» («воздушный удар» и также «удар по воздуху», в связи с войной с Югославией) (Metzler Lexikon Sprache, „Schlagwort““, с. 604). Про актуальные для России политические ключевые слова cp. Spraul 1998. 
«единое пространство». Среди окружения найденных отрывков ведется поиск других ключевых слов, которые могут иметь значение для раскрытия искомой концепции. При этом необходимо выяснить семантические аспекты ключевого слова, в первую очередь с помощью коллокации (в примере с федерализмом речь может идти о «едином политическом, правовом, экономическом или финансовом пространстве»).

б) Редукция до релевантных для исследования отрезков текста. Цель данного этапа - выявить как можно меньшее количество отрывков текста, передающих все важнейшие элементы дискурса и тем самым наиболее полно - стоящую за ним концепцию. Для этого используются наиболее насыщенные цитаты. Интуитивные решения играют при этом важную роль. Однако более-менее формальный критерий мог бы быть полезен.

Из опыта известно, что «темные места», высказывания, значение которых не ясно с первого взгляда и которые особенно нуждаются в пристальном анализе, оказываются наиболее содержательными. Это может объясняться большой эмоциональностью (намеренной или ненамеренной) или особенно сильной противоречивостью (и то, и другое указывает на релевантность цитат). Как правило, это те места в тексте, в которых особенно часто встречаются метафоры, фреймы, пресуппозиции, пропозициональные противоречия или слабые места с формальнологической точки зрения (тавтологии, плеоназмы, и т. п.) - или слаба связность текста. В процессе работы выяснилось, что как раз такие темные места в корпусе могут быть наиболее плодотворны для исследования. Они дают указание на искомые наиболее насыщенные цитаты.

Чтобы теперь сократить найденные цитаты до минимума, следует разбить и разложить отрывки текста по подтемам, чтобы потом уже эффективно удалить лишнее и исключить избыточные места, повторяющиеся аргументации и т. д. При этом выборе следует всегда отдавать предпочтение более насыщенным цитатам ${ }^{17}$.

Важным требованием к цитатам является их связностью с другими цитатами. Отрывки текста должны рационально вписываться в целое дискурса - это главное требование реконструкции. Формально это требование может быт выражено так: любой отрезок текста должен быть дискурсивно связанным как минимум с еще одним отрезком (дискурсивная когеренция, см. ниже), в противном случае следует найти новые тексты или исключить данный текст из корпуса.

\footnotetext{
${ }^{17}$ Найденные в проведенном анализе отрывки сначала имели как правило объем от одного до трех абзацев и тематически распространялись на много подтем. Обычно выявленные и сокращенные до необходимого минимума цитаты были больше одного предложения, но меньше абзаца (чаще всего - 2-3 предложения, иногда с сокращениями).
} 
Этот критерий одновременно и выполняет роль страховки против переинтерпретации отдельных цитат - ведь если высказывание логически вписывается в ряд других, то (учитывая указанные выше особенности политического языка) с достаточно высокой степенью уверенности можно утверждать, что эта цитата - не «ляпсус», а выражение части действительно стоящей за дискурсом концепции.

Шаги а) и б) следует повторять, пока корпус не будет полон. Полным же его можно считать, когда новые отрывки текста не вносят дополнительных подтем или содержательно-концептуальных результатов, т. е. каждая новая цитата ведет только к избыточности.

в) Упорядочение, при котором когерентные между собой элементы ставятся как можно ближе друг к другу. Как при соответствующем тема-рематическом членении, цитаты внутри одной подтематической единицы должны давать более точное определение упомянутого, но не объясненного подробнее в предыдущей цитате предмета, давать разрешение пропозиционального противоречия, и т. п. То же самое можно сказать о макроструктурах, упорядочивающих группы цитат. В результате получается упорядоченный, окончательный вариант корпуса для анализа, включая предварительное членение на основополагающие категории дискурса и их аспекты (см. также ниже) $)^{18}$.

Это упорядочение цитат, а также их распределение по основополагающим категориям дискурса и их аспектам в основном уже является результатом анализа содержания корпуса и будет освещено подробнее в следующем параграфе. Ведь именно упорядочение цитат предполагает знание их содержания и их структурных взаимоотношений, т. е. результатов анализа. Так что, строго говоря, корпус оказывается только тогда действительно и окончательно составлен и упорядочен, когда анализ завершен.

\section{Анализ корпуса}

Целью анализа является дешифровка корпуса, т.е. анализ значения и внутренних связей релевантных цитат. Средством для этого служит лингвистический анализ отдельных цитат «конвенциональными» средствами анализа текста, в частности: анализ пропозиций, исследование

${ }^{18}$ Например, в случае российского политического дискурса о федерализме из всего корпуса речей, выступлений и т. д. президента Путина в промежуток времени с 21.01.2000 по 12.11.2001 (всего 359 текстов) было найдено 64 текста с высказываниями на тему российского федерализма. Шаги б) и в) привели к созданию готового для анализа корпуса. Из оставшихся 28 текстов, наиболее соответствовавших теме и позволявших полно и точно описать президентскую концепцию федерализма, была выбрана 61 относительно короткая и насыщенная цитата. Их упорядочение не соответствует хронологии исходных текстов, и отрывки из одного и того же текста находятся в измененном порядке вперемешку с цитатами из других текстов. 
метафорики, пресуппозиций, импликатур, и т. д., а также анализ стиля и прагматики.

Ниже мы кратко опишем основные особенности исследования цитат методами анализа текста, чтобы показать, как в конце концов может быть проведена реконструкция структуры концепций.

г) Исследование цитат.

Точный анализ найденных цитат может быть проведен в форме постоянной постановки продолжающих друг друга вопросов к корпусу и нахождения ответов в нем же: исследуются более точные содержательные свойства каждой фразы и каждого понятия, оказывающихся в процессе анализа центральными. Эти свойства могут быть выяснены, в первую очередь, через их когерентность (англ. coherence, нем. Kohärenz).

С помощью понятия когерентности можно выяснить и структурные отношения частей политического дискурса. Таким способом могут быть объяснены и высказывания, содержащиеся в речи не эксплицитно. Как уже было сказано, при анализе политических текстов это особенно важно. Таким образом, можно сказать, что решающим параметром при точном анализе корпуса (как и в лингвистике текста), выступает когеренция.

Так как речь здесь идет лишь виртуально об одном тексте, в реальности же - о субстрате целого ряда текстов, здесь нельзя говорить и о формальной связности, о когерентности текста. Вместо этого мы предлагаем говорить о дискурсивной когерентности. Как и когерентность текста, она основывается на сети изотопии, на рекуррентности признаков, но распространяется на превосходящее текст единство дискурса.

Анализ когерентности при этом выявляет «скрытые» связи высказываний политиков. В нашей работе это играет особо важную роль из-за уже упомянутой склонности политических актеров к туманности и имплицитности высказываний.

Дискурсивная когерентность связана с уровнем политической концепции, содержащейся в различных высказываниях (даже различных актеров), имеющих различных адресатов и появившихся в разное время в различных СМИ.

Непосредственно на поверхности текста нет формальной связи, напротив, анализ освобождается от «материальных» временных и текстуальных линейно организованных связей высказываний, концентрируясь на когнитивно организованном, логически когерентном уровне концепции. Поэтому интертекстуальная формальная связность (англ. coherence, нем. Kohärenz) практически не имеет значения в предложенном здесь анализе дискурса. 
Дискурсивную когерентность, так же как и текстуальную, можно разделить на семантическую, риторико-стилистическую и прагматическую. На первом плане находятся семантическая когерентность. Семантические связи рассматриваются не только в отношении отдельных слов, но и фразеологизмов и частей предложений. Она реализуется через семантические отношения, такие как гипо- и гиперонимия, синонимия, антонимия, комплементарность, импликация и пресуппозиции, а также через метафорическую когерентность. Некоторые семантические связи можно хорошо определить с помощью концептов «фрейм» и «сценарий» ${ }^{19}$.

Для выявления семантических связей различных элементов дискурса, в первую очередь, выраженных метафорически, при анализе метафорической когерентности полезными оказываются систематизирующие подходы, такие как метод Лакоффа/Джонсона. Метафора может быть систематически объяснена с помощью других метафор, подчиненных ей и подчеркивающих связи с отдельными частными свойствами предмета. Когерентность важна для соединения всех частей метафорической структуры внутри концепта, а также для включения концептов в превосходящие их более сложные структуры. (О метафорической когерентности см. Lakoff/Johnson 2000: 87-105) $)^{20}$.

В аналитической практике наиболее важным оказалось исследование импликаций, пресуппозиций и импликатур. Импликации представляют собой связки двух высказываний с помощью оператора «если то» ${ }^{21}$. Пресуппозиции также позволяют говорящему включить в выска-

${ }^{19}$ Как социальный фрейм следует понимать, например, путинскую характеристику главы региона как «первого секретаря» - этим он касается в разговоре с губернаторами общего политического опыта советского периода (через гипонимную оппозицию с «полновластный хозяин на своей территории», здесь с положительной коннотацией, Путин 2000c). В другом месте, однако, Путин критикует метафорическое обозначение губернатора как «царь» (с отрицательной коннотацией, Путин 2000b). Такие кажущиеся противоречия должен объяснить точный анализ.

${ }^{20}$ Так, например, в дискурсе о федерализме нынешний российский президент метафорически называет «государство» «машиной»: «Нам нужно создавать систему, которая просто функционировала бы как машина вне зависимости от наших с вами личных и деловых качеств [...] машина должна функционировать и должна действовать эффективно для всего общества в целом и для отдельных регионов в частности» (Путин 2000с). В другом месте Президент называет «закон» «инструментом»: «Ведь государство - [...] это прежде всего закон, это конституционный порядок и дисциплина. Если эти инструменть слабы, то слабо и государство, или его попросту нет» (Путин 2000а). Исследование высказываний президента, связанных с такой метафорикой, дало следующую картину: чтобы «инструмент» «государственной машины» - закон - «имел силу», должен существовать «механизм» для трансмиссии силы инструмента. (Например: «А почему не исполняется $[$ закон, Я.Ф.]?» «А потому, что нет механизма, который бы заставлял исполнять» (Путин 2000c).) Налицо метафорическая когерентность. Подробный анализ см. в Fruchtmann 2003:134-147.

21 При импликации аподосис перевешивает протасис по своему истинностному значению. Большую помощь для точного выяснения семантических связей могут оказать 16 
зывание положение вещей и обстоятельства дела, не эксплицируя их. Понятие пресуппозиции служит в лингвистике текста для определения и объяснения функций внеязыковых знаний в конституции текстовой когерентности. В прикладном анализе политического дискурса оно служит для исследования многозначных или «неопределенных» комплексных высказываний и для выявления связей ${ }^{22}$.

Области прагматической когерентности явно принадлежат импликатуры (также речевые импликатуры, т. к. они основываются на общепринятом значении языковых выражений $)^{23}$. Импликатуры представляют собой важное средство анализа когерентности политических текстов, т.к. они позволяют неопределенность в выражения и одновременно могут иметь высокую степень эмоциональности или силы риторического воздействия.

Речевые акты с их различными иллокуциями также могут давать дискурсивную когерентность. В политическом языке повышенную роль играют директивные речевые акты, такие как побуждения ${ }^{24}$. Особо важен речевой акт угрозы ${ }^{25}$. Если политическая концепция некоего актера содержит угрозы, побуждения и т. д., то они могут быть выражены самыми разными языковыми средствами. Задачей анализа является вос-

формально-логические тесты. Так, асимметрия импликации запрещает менять местами протасис и аподосис (тест на асимметрию, * «если b, то а»).

22 Так называемые знаковые пресуппозиции разделяются на референциальные и семантические. Оба типа связаны с эксплицитными элементами текста, даже не будучи эксплицироваными (референциальная пресуппозиция означает, что обозначенный в референциальной части высказывания предмет также существует). Их можно однозначно определить с помощью тестов: Если условие действительно и тогда, когда высказывание отрицается, то это пресуппозиция. Узуальная (или «прагматическая») пресуппозиция не свойственна никакому отдельному выражению и образует переходную категорию между семантическим и прагматическим типами когеренции. Когерентность возникает здесь, если два или более синтаксически и по содержанию не связанные прямо друг с другом значения могут быть коммуникативно осмысленно связаны друг с другом на основе не реализованных в тексте, обращающихся к «общему знанию» мысленных промежуточных шагов. Таким образом прагматические пресуппозиции могут давать когерентность, но при этом они требуют особой тщательности анализа из-за слабой формальной связности. Ср. Linke/Nussbaumer 1988.

23 Если при импликации аподосис по своему истинностному значению влияет на протасис, то при импликатуре это не так, т. к. тогда истинность имплицированного аподосиса важна не для истинности выраженного протасиса, а для его коммуникативного соответствия. Импликатурный тест поэтому невозможен. (Cp. Grice 1975, S. 41-56. Более актуальный обзор в Kemmerling 1991).

${ }^{24}$ То есть иллокутивные акты, общей чертой которых является то, что слушающий должен быть побужден говорящим к некоему действию (или к избеганию некоего действия), например, просьбы, приказы, требования (ср. Searle 1982:45).

${ }^{25}$ Писаркова описывает способ его функционирования в политической коммуникации вне зависимости от других побудительных актов, таких как обещание или предупреждение. Cp. Pisarkowa, Krystyna. Androhung als Sprechakt - Versuch einer Stellenwertbestimmung. // Sandig, Barbara (Hg.) Stilistisch-rhetorische Diskursanalyse. Tübingen, 1988, S. 75-86. 
становление связей между такими разнообразными языковыми высказываниями.

В области стилистической когерентности для анализа политических дискурсов наиболее важны те, которые лежат на границе формы и содержания, где говорящий способом своего высказывания может выдать что-то о своем отношении к адресату. Так, например, стиль речи Путина иногда отличается сильной модальностью при слабой персональности - этот момент позволяет установить когерентность между стилистически таким образом маркированными элементами. Наконец, стилистическая когерентность может быть выражена в форме повторяющихся или похожих риторических фигур и часто образует пересекающиеся массы с различными видами семантической когерентности ${ }^{26}$. Однако, как правило, стилистические когерентности только помогают раскрытию семантических, обычно они не конституируют самостоятельно элементы политической концепции.

В результате анализа постоянно появляются и указания на непосредственную связь высказываний с общим контекстом дискурса. Стремление заново наполнить политически или переосмыслить некое понятие можно часто увидеть уже в тексте самом по себе, еще до того, как станет известно, как оно наполнялось ранее. Для анализа таких явлений подходит классификация, предложенная Клейном в статье о политической метафорике «наполнения понятий» (нем. Umbesetzung). $\mathrm{OH}$ подразделяет политическую конкуренцию понятий на а) концептуальную конкуренцию через введение новых понятий, б) конкуренцию определений через пристрастную предикацию, в) дескриптивная конкуренция значений через изменение значений, г) деонтическую конкуренцию значений через переоценки и д) конкуренцию через использование коннотаций. (Cp. Klein 1989a. Примерно то же можно найти в его же статье 1989b).

д) Реконструкция структуры концепций.

Составными частями политического дискурса, используя метод описания дискурсов Юргена Линка, могут быть названы, в первую очередь, так называемые основополагающие категории дискурса (нем.: „diskurstragende Kategorie“, Link 1997: 15). Но для прикладного анализа политических дискурсов такое членение еще очень приблизительно. В процессе анализа выяснилось, что основополагающие категории дискурса подразделяются на различные аспекты, которые в свою очередь определяются элементами дискурса. Как наименьший фрагмент дискур-

${ }^{26}$ Риторические фигуры понимаются здесь как «отклонения от прямого, гладкого и плоского способа выражения, [...] Фигуры понимаются как выражение движения, аффектов, жизни. В формализованном риторическим искусством виде они составляют репертуар способов и процессов, служащих для оживления каменного (а именно - логических понятий) или для актуализации в новой форме окаменевшего». (Ueding/Steinbrink 1994:276). 
са, выражающий политическую концепцию, можно в итоге выделить дискурсему, из которых они и состоят.

При анализе должны быть в первую очередь выявлены основные семантические аспекты, организующие дискурс, которые Линк назвал «основополагающими категориями дискурса». Линк определяет основополагающие категории дискурса следующим образом:

«Основополагающие категории дискурса - это такие категории, при удалении которых из дискурса, если, так сказать, втянуть их из дискурса, как стальной каркас из бетонной конструкции, данный дискурс не выдержит и развалится, как карточный домик. Под такими категориями следует, как правило, понимать не изолированные отдельные слова, а целые семантические комплексы, включая их связь с практикой, что опять же сравнимо с перекрестными стальными конструкциями в бетоне» (Link 1997: 15).

Такими «семантическими комплексами» рассматриваются при анализе одновременно и важные категории, делящие выявляемые концепции по содержанию и тематике, а также прямые языковые цитаты, ключевые слова, вокруг которых группируются существенные части концепций. Это довольно надежно действует в случае политического языка, т.к. такие ключевые слова, как правило, создаются целенаправленно и должны ассоциироваться с важными и характерными чертами политических концепций актеров (как например, в путинском дискурсе о федерализме: «единое пространство», «вертикаль власти», «диктатура закона» и «система межбюджетных отношений»).

Метафорическое описание Линка может быть дополнено формальными критериями. Так, изучение дискуссий в СМИ ведет к ясному выделению основополагающих категорий дискурса, т.к. общественность касается их метадискурсивно - эксплицитно или имплицитно. Эксплицитные метадискурсивные связи состоят в использовании определенных ключевых слов в кавычках и/или с указанием на политического актера, с которым они связываются, и/или с объяснениями типа «концепция/план/стратегия/цель персоны X по проблеме Y». Многие комментаторы актуальных политических событий в России используют, например, выражение «...путинская «вертикаль власти»...», ставя это выражение в кавычки - это явное указание на эксплицитную дискурсивную когерентность.

Целью дальнейшего анализа является объяснение, как устроены основополагающие категории дискурса, как они оформлены содержательно и подтематически, как структурированы их аспекты и элементы.

В отличие от основополагающих категорий дискурса их аспекты не обязательно представляют собой цитаты (как в выше приведенном примере), они не обязательно связаны с ключевыми словами и могут быть 
выдвинуты исследователем в качестве «подпунктов» его анализа. В нашем примере разграничение аспектов ясно подтвердилось в результате анализа, т. к. они на самом деле демонстрировали высокую степень дискурсивной когерентности.

Аспекты основополагающих категорий дискурса в свою очередь складываются из отдельных обобщающих комплексов фраз, которые мы называем элементами дискурса. Содержание элементов дискурса и их отношение друг к другу образуют структуру аспектов основополагающей категории дискурса и являют собой ядро результатов аналитической работы.

В свою очередь элементы дискурса состоят из дискурсем, т. е. наименьших дискурсообразующих единиц значения, но они, как правило, сами по себе недостаточны для образования целого элемента дискурса. Каждая дискурсема должна быть верно доказуема/выводима при помощи как минимум одной цитаты и иметь вид простого предложения, по возможности, с единственной (как можно более простой) пропозицией ${ }^{27}$.

С целью исследования согласуется стремление формулировать как можно более простые, краткие, безличные фразы, чтобы они по возможности имели форму $\mathrm{A}=\mathrm{B}$, и которые на самом деле годятся для снижения сложности, неопределенности и иллокутивной силы политического языка.

\section{Перспективы исследования}

Когда таким образом выявлены элементы и структура политического дискурса одного актера (или более-менее гомогенной группы актеров, как, например, актеров определенной партии), могут быть составлены систематические отношения к высказываниям других актеров или групп актеров. Самые интересные группы тут состоят из актеров второго плана - т. е. из пострадавших от политики актера-инициатора, или целевой группы его действий (в случае реформы федерализма, например, это прежде всего были губернаторы, в случае реформы банковской системы это были бы банки и т. д.). При анализе высказываний этих актеров второго плана применяется тот же описанный выше метод.

Разложение дискурса актера-инициатора на его различные структурные элементы, связанные с определенными политическими ключевыми словами, позволяет описать дискурсивные стратегии актеров второго плана в их интертекстуальном отношении к актеру-инициатору.

\footnotetext{
27 Примером такого элемента дискурса из политического аспекта «единого про-

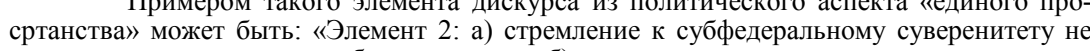
допускаются ни при каких обстоятельствах; б) суверенитет - эксклюзивное верховенство; в) только российское государство, в лице федерального уровня власти, имеет право на суверенитет». В следующем можно сослаться на цитаты, из которых был выделен этот элемент дискурса. Предложение а)-в) являются дискурсемами.
} 
При этом следует развернуть материал - особенно если актеруинициатору удалось добиться гегемонии в дискурсе - по различным вариантам точек зрения на каждую основополагающую категорию дискурса. Так в разобранном примере с российским дискурсом о федерализме можно наблюдать среди губернаторов разброс стратегий от полного согласия до абсолютного отрицания. Таким способом можно однозначно установить, мог ли актер-инициатор завоевать гегемонию в дискурсе или нет.

Различные стратегии дискурса позволяют, наконец, составить типологию актеров второго плана. В нашем примере, к типу «оппортунистов» относятся губернаторы, следовавшие стратегии полного согласия с дискурсом президента или полного согласия с некоторыми уступками, вплоть до следовавших стратегии опережающего повиновения. К типу «готовой к переговорам оппозиции» относились губернаторы со стратегиями ориентированного на согласие противоборства, готового к переговорам отрицания, или ориентировки на предшествующий статус кво. К «оппозиции» относились губернаторы, нападавшие на отдельные элементы дискурса, чтобы дать отпор их прагматике или возразить против уже проведенных политических мероприятий, а также губернаторы, придерживавшиеся оппозиционной стратегии из разочарованной лояльности. К «всеотрицающим», наконец, относились губернаторы со смешанной стратегией готового к переговорам отрицания, стратегией полной или несмягченной оппозиции, вплоть до отдельных губернаторов, придерживавшихся стратегии полного отказа. Точки зрения губернаторов имели в каждом случае различный центр тяжести по отношению различных основополагающих категорий дискурса, типичные также для их поражения или интересов.

Таким образом, описанным здесь методом можно методически обоснованно и конкретно описать дискурсивные связи, переплетения текстов и их взаимодействие в общем политическом процессе.

$$
\text { Литер атура }
$$

1. Bartsch R. / Vennemann T. (1980): Sprachtheorie, in: Althaus, H. P. / Henne H. / Wiegand H. E.: Lexikon der Germanistischen Linguistik, Tübingen, S. 57-82.

2. Busse, Dietrich / Teubert, Wolfgang (1992): Antrag auf Einrichtung einer AG Diskursgeschichte / Begriffsgeschichte. Methodenproblem und Fallstudien, in: Bulletin der Deutschen Gesellschaft für Sprachwissenschaft 35/1992.

3. Dieckmann, Walther (1980): Sprache in der Politik, in: Greiffenhagen, M. (Hg.): Kampf um Wörter? Politische Begriffe im Meinungsstreit, Bonn, S. 47-65.

4. Edelman, Murray (1980): Politische Sprache und politische Realität, in: Greiffenhagen, M. (Hg.): Kampf um Wörter? Politische Begriffe im Meinungsstreit, Bonn, S.39-46.

5. Fruchtmann, Jakob (2003): Der russische Föderalismus unter Präsident Putin: Diskurse Realitäten, Bremen. Опубл. в интернете: http://elib.suub.unibremen.de/publications/dissertations/E-Diss537_Fruchtmann.pdf. 
6. G. Ueding, G. / Steinbrink, B. (1994): Grundriß der Rhetorik, Stuttgart.

7. Gramsci, Antonio (1983): Marxismus und Kultur. Ideologie, Alltag, Literatur, Hamburg.

8. Grice, H. P. (1975): Logic and conversation, in: Cole, P. / Morgan, L. (Hrsg.), Syntax and semantics, Bd. 3: Speech acts, New York, S. 41-56.

9. Hartwich, H. H. (Hrsg.) (1985): Policy-Forschung in der Bundesrepublik Deutschland, Opladen.

10. Jäger, Siegfried (2001a): Discourse and Knowledge. Theoretical and methodological aspects of a critical discourse and dispositive analysis, in: Wodak, Ruth / Meyer, Michael (Hg.): Methods of Critical Discourse Analysis, London, S. 32-62.

11. Jäger, Siegfried (2001b): Diskurs und Wissen. Theoretische und methodische Aspekte einer Kritischen Diskurs- und Dispositivanalyse, in: Keller, Reiner et al. (Hrsg.): Handbuch Sozialwissenschaftliche Diskursanalyse, Bd. 1: Theorien und Methoden, Opladen, S. 81112.

12. Jung, M. (1996): Linguistische Diskursgeschichte; in: Böke, K. / Jung, M. / Wengeler, M. (Hrsg.): Öffentlicher Sprachgebrauch. Praktische, theoretische und historische Perspektiven, Opladen, S. 453-473.

13. Kemmerling, A. (1991): Implikaturen, in: Stechow, A. von / Wunderlich, D. (Hrsg.): Semantik/Semantics. Ein internationales Handbuch der zeitgenössischen Forschung. An International Handbook of Contemporary Research, Berlin, S. 319-333.

14. Klein, Josef (1989a): Kann man „Begriffe besetzen“? Zur linguistischen Differenzierung einer plakativen politischen Metapher, in: Liedtke, Frank / Wengeler, Martin / Böke, Karin (Hg.): Begriffe besetzen. Strategien des Sprachgebrauchs in der Politik, Opladen, S. 44-70.

15. Klein, Josef (1989b): Wortschatz, Wortkampf, Wortfelder in der Politik, in: Klein, Josef (Hg.): Politische Semantik. Bedeutungsanalytische und sprachkritische Beiträge zur politischen Sprachverwendung, Opladen.

16. Knobloch, C. (1998): Politische Kommunikation, Tübingen.

17. Laclau, Ernesto / Mouffe, Chantal (1995): Hegemonie und radikale Demokratie. Zur Dekonstruktion des Marxismus. Wien.

18. Lakoff, George / Johnson, Mark (2000): Leben in Metaphern. Konstruktion und Gebrauch von Sprachbildern, Heidelberg.

19. Link, Jürgen (1997): Versuch über den Normalismus, Opladen.

20. Linke, Angelika / Nussbaumer, Markus (1988): Kohärenz durch Präsuppositionen?, in: Der Deutschunterricht 6/1988, S. 29-53.

21. Pisarkowa, Krystyna (1988): Androhung als Sprechakt - Versuch einer Stellenwertbestimmung, in: Sandig, Barbara (Hg.): Stilistisch-rhetorische Diskursanalyse, Tübingen, S. 75-86.

22. Путин В.В. (2001): Выступление Президента Российской Федерации В.В. Путина на заседании Государственного совета Российской Федерации, Москва, 22.11.2000, опубл. в интернете: http://www.president.kremlin.ru/events/105.html (по состоянию на январь 2001).

23. Путин В.В. (2000а): Телевизионное обращение к гражданам России, 17.05.2000, Москва. Опубл. в интернете: http:/www.president.kremlin.ru/events/34.html (по состоянию на август 2000).

24. Путин В.В. (2000b): Россия не должна быть и не будет полицейским государством // Известия, 14.07.2000. Опубл. также в интернете: http://www.president.kremlin.ru/events/46.html (по состоянию на июль 2000).

25. Путин В.В. (2000c): Выступление Президента Российской Федерации В.В. Путина на совещании по вопросам развития Уральского федерального округа, Нижний Тагил, 14.07. 2000, опубл. в интернете: http://www.president.kremlin.ru/events/49.html (по coстоянию на август 2000).

26. Рассошенко Ж.В. (2003): К вопросу об определении дискурса в современной лингвистике // Язык, Сознание, Коммуникация. М., 2003. Вып. 24. С. 86-98. 
27. Searle, John R.: Ausdruck und Bedeutung. Untersuchungen zur Sprechakttheorie, Frankfurt a.M. 1982.

28. Spraul, H. (1998): Das politische Schlagwort in der neuen russischen Presse (1995-1997). Zum Sprachwandel in der öffentlichen Rede, in: Zeitschrift für Slawistik 2/1998, S.165177.

29. Titscher, Stefan / Meyer, Michael / Wodak, Ruth / Vetter, Eva (2000): Methods of text and discourse analysis, London u.a. 2000.

30. van Dijk, Teun A. (1980): Macrostructures. An interdisciplinary study of global structures in discourse, interaction and cognition, Hillsdale, N.J..

31. Weller, Christoph (2002): Die massenmediale Konstruktion der Terroranschläge am 11 September 2001. Eine Analyse der Fernsehberichterstattung und ihre theoretische Grundlage, INEF Report 63/2002 (Institut für Entwicklung und Frieden der Gerhard Mercator Universität Duisburg).

32. Windhoff-Héritier, Adrienne (1987): Policy-Analyse: Eine Einführung, Frankfurt a.M.. 


\title{
Современные подходы к изучению дискурса
}

\author{
(C) E. В. Темнова, 2004
}

Несмотря на то, что исследования в области дискурса ведутся на протяжении почти полувека, интерес к данному явлению не иссякает, и связано это прежде всего с тем, что данное понятие не имеет четких рамок. Неудивительно, что некоторые предпочитают считать его скорее словом-паразитом.

Тем не менее, следует признать, что дискурс является сложным коммуникативным явлением, обладающим дифференциальными особенностями, которые одни ученые связывают с продуктом речевого действия с присущей ему смысловой однородностью, актуальностью (уместностью), привязанностью к определенному контексту, жанровой и идеологической принадлежностью (Т.А. ван Дейк, В. Кинч, В.З. Демьянков, А.Е. Кибрик, И.М. Кобозева, W. Chafe, W. Labov и др.), а другие (О.В. Александрова, Е.С. Кубрякова, В.В. Красных и др.) отождествляют с вербализованной деятельностью с присущей ей соотнесенностью с целым слоем культуры, социальной общности и даже с конкретным историческим периодом. В русле лингвистической традиции такая широкая парадигма изучения дискурса обусловлена, вопервых, мультидисциплинарностью подхода (исследование дискурса ведется в соответствии с основными тенденциями развития и разработками смежных дисциплин: литературоведения, лингвистики, социальной семиотики, теории искусственного интеллекта, психологии, логики, этнографии, политологии и т. п.), а во-вторых, синтезом двух ведущих направлений современности - когнитивного и коммуникативного. Необходимо подчеркнуть, что дискурсивные исследования в рамках разных областей лингвистики (стилистики, лингвистики текста, исследований разговорной речи), а также в области когнитивистики принимают во внимание непосредственно языковую сторону дискурса, тем самым отграничивая его от других явлений языка. В отличие от текста или речи дискурс включает понятие сознания.

В связи с таким обширным спектром дискурсивных подходов Т. ван Дейк [3] предлагает различать два определения дискурса. В широком смысле дискурс есть комплексное коммуникативное событие, происходящее между говорящим и слушающим (наблюдателем), в определенном временном, пространственном и прочем контексте. Коммуникативное действие может быть речевым, письменным, а также иметь вербальные и невербальные составляющие (например, разговор с другом, диалог между пассажирами транспорта, чтение газеты). 
В узком смысле дискурс есть текст устный или письменный с учетом присутствия только одной вербальной составляющей. С этих позиций термин «дискурс» обозначает завершенный или продолжающийся «продукт» коммуникативного действия, его письменный или устный результат, который интерпретируется реципиентами (например, вербальный продукт - письменный или устный - коммуникативного действия) [3]. Согласно концепции Т. А. ван Дейка, рассмотрение принципов функционирования языка в обществе ведется не только с точки зрения прагматических подходов к дискурсу, но также с учетом определенных социальных факторов (мнения и установки говорящих, их социальный и этнический статус и т. д.); определенным образом акцентируются личностные характеристики носителей языка с их намерениями, чувствами, эмоциями и проч.

Модель понимания дискурса взаимодействует с моделью его когнитивной обработки, таким образом делая его предметом когнитивной лингвистики. Так как в дискурсе отражена иерархическая сущность разных видов знаний, необходимых как для порождения, так и для понимания речи, в ходе развития и тех, и других процессов участвуют стратегии отбора наиболее значимой информации, значимой в данном контексте и для данных коммуникантов.

В ходе рассмотрения существующих на данный момент значений слова «дискурс» следует подчеркнуть, что изначально во французской лингвистической традиции слово «дискурс» обозначало речь вообще, текст (фр. discours - речь, тип речи, текст, тип текста), и дискурс рассматривался безотрывно от своего лексического значения и отождествлялся с речью или речевой коммуникацией.

Термин «анализ дискурса» был впервые использован 3. 3. Харрисом, который пытался распространить дистрибутивный метод с предложения на связный текст [12]. До начала 70-х гг. лингвистика редко выходила за рамки предложения. Ю. Хабермас одним из первых обратил внимание именно на ту сторону понятия дискурса, которая непосредственно связана с речью и впервые представил термин «дискурс» сквозь призму социологического аппарата для обозначения вида речевой коммуникации с учетом общественных норм, правил и ценностей социальной жизни. Однако Э. Бенвенист придал ему терминологическое значение, обозначив им «речь, присваиваемую говорящим» [6]. Поэтому понимание дискурса может быть сведено к самой процедуре порождения текста говорящим. В теории Э. Бенвениста дискурс противопоставлялся объективному повествованию (recit), вследствие этого понятие дискурса было распространено на все виды прагматически обусловленной и различающейся по своим целеустановкам речи. 
Итак, понятие дискурса является очень емким, включающим обширный спектр характеристик как лингвистического, так и экстралингвистического свойства, которые позволяют рассматривать его в качестве продукта речевого действия с присущей ему смысловой однородностью, актуальностью (уместностью), привязанностью к определенному контексту, жанровой и идеологической принадлежностью, а также соотнесенностью с целым слоем культуры, социальной общности и даже с конкретным историческим периодом.

Дискурс также может отождествляться с текстом, однако, необходимо уточнить, с какого рода текстом можно проводить параллели: это может быть текст, который состоит из коммуникативных единиц языка - предложений и их объединений в более крупные единства, находящиеся в непрерывной смысловой связи. Другими словами, дискурс - это не только связная последовательность предложений, противопоставляемая изолированному предложению, но и определенное семантическое единство, обладающее семантической связностью (когезией). Последняя, в свою очередь, проявляет связность информационную, т. е. знания о мире, о ситуации, социальные и культурологические знания и прочие виды знаний.

Как подтверждение этой мысли следует привести высказывание Ю. Руднева: «Дискурс - такое измерение текста, взятого как цепь / комплекс высказываний (т. е. как процесс и результат речевого (коммуникативного) акта), которое предполагает внутри себя синтагматические и парадигматические отношения между образующими систему формальными элементами и выявляет прагматические идеологические установки субъекта высказывания, ограничивающие потенциальную неисчерпаемость значений текста» [9]. Еще один аспект дискурсивной парадигмы, включающий своеобразный антропологический подход, базируется на мысли о том, что в дискурсе главным образом отражается физическое пространство человека, поэтому важная роль в этом принадлежит языковой личности, а сам дискурс антропоцентричен.

А.А. Кибрик и В.А. Плунгян трактуют дискурс как более широкое понятие, чем текст: под дискурсом можно понимать одновременно и процесс языковой деятельности, и ее результат [10].

Таким образом, дискурс имеет два плана. С одной стороны, дискурс ассоциируется с понятием речи, или точнее связной речи, потоком речи, сложным синтаксическим целым, сверхфразовым единством, текстом, коммуникативно целостным и завершенным речевым произведением, а также характеризуется коммуникативной адекватностью. Данная сторона дискурса выражается в языковом инструментарии и проявляется в совокупности порожденных текстов. 
Второй план дискурса затрагивает ментальные процессы участников коммуникации: этнические, психологические, социокультурные стереотипы и установки, а также стратегии понимания и порождения речи, определяющие при необходимости темп речи, степень ее связности, соотношение общего и конкретного, нового и уже известного, нетривиального (субъективного) и общепринятого, эксплицитного и имплицитного в содержании дискурса, выбор средств для достижения конечной цели коммуникации, фиксацию точки зрения говорящего и т. д. Поэтому дискурс можно рассматривать как «связный текст в совокупности с экстралингвистическими, социокультурными, психологическими и другими факторами; текст, взятый в событийном аспекте» [2].

Как уже упоминалось выше, некоторые иссдедователи дискурса склонны отождествлять его с определенной текстовой структурой, которая, однако, обусловлена социальным контекстом. По мнению В. В. Красных, «дискурс есть вербализованная деятельность, понимаемая как совокупность процесса и результата и обладающая как собственно лингвистическим, так и экстралингвистическим планам» [6]. Поэтому дискурс можно рассматривать как единый организм, в котором в одно и то же время реализуются аспекты не только языка, но и языкового мышления.

Философские концепции дискурса не связаны с изучением принципов устройства текста. В построении теории дискурса М. Фуко вопросы о пользователях языка или конструктах бытования языка (речепроизводстве, связности, адекватности, а также понимании текста) полностью отсутствуют. Прежде всего данная теория базируется на концепции «бессубъектного дискурса» [8: 270], который не зависит от преходящих людей - пользователей языка и сменяющихся ситуаций общения, а просто существует на уровне материальной субстанции. Таким образом, М. Фуко занимался проблемой реализациии определенных дискурсивных практик, которые, по его мнению, заключаются в совокупности анонимных исторических правил, всегда определенных во времени и пространстве, установленных в данную эпоху и для данного социального, экономического, географического или лингвистического пространства путем выполнения функции высказывания [11]. Поэтому с данных позиций дискурс можно воспринимать как единое внешнее пространство, в котором размещается сеть различных (временных и пространственных) характеристик, позволяющие выйти за пределы одного текста и проникнуть в разные тексты. Под дискурсивными практиками понимается анонимный исторический свод правил, которые были заданы в определенную эпоху и в определенном географическом, политическом, экономическом, социальном или лингвистическом пространстве в соответствиями с условиями выполнения функции высказывания. 
В рамках литературоведения исследуют макроструктуры дискурса: смену и мотивацию сюжетов, мотивов, жанров и т. П., то есть дискурс рассматривается с помощью литературоведческого инструментария.

Лингвистика же занимается микроуровнем, ее предметом являются: а) синтактика, семантика и прагматика дискурсов, б) инсценировка и модели интерпретации этих дискурсов. В частности, именования значимых концептов в специфическом (например, политическом, искусствоведческом) употреблении в сопоставлении с обыденным языком.

Исследования дискурса с семиотических и социологических позиций ведется в режиме дискурсивных практик, с помощью которых структурируются эпистемы как инварианты научного мышления разных эпох с целью найти ответ на вопрос о том, как бытийствует язык.

На современном этапе развития анализа дискурса понимание самого термина колеблется от почти синонимического терминам речь, или поток речи, сложное синтаксическое целое, текст до определенного типа ментальности; от вербализованного сознания до сложного коммуникативного явления, включающего экстралингвистические факторы, оказывающие влияние на его производство и восприятие; от фиксированного текста, содержащего авторизованную модель реального мира до дискурса как определенного измерения существования языка.

Как сложная когнитивная структура дискурс претерпевает действие нескольких когнитивных принципов, которые в частности включают: 1) принцип иконичности [10], в основе которого лежит отражаемое в языке соответствие между представлениями о мире и репрезентацией этого представления в языке, в то время как упорядоченность восприятия реальности отражается через посредство определенным образом упорядоченных элементов текста, обусловленных пространственно, хронологически, каузально или социально и 2) принцип разделения информации на данную [10] (ту, которая по презумпции говорящего знакома адресату) и новую (неизвестную адресату). Передача информации ведется на основе синтеза фоновых знаний и конкретного контекста. Данные принципы неразрывно связаны с основной чертой логического рассуждения, в котором каждая мысль, вытекающая из предыдущей и обусловливающая последующую, существует в виде заключения и строится на знании, возникшем путем обобщения некоторой совокупности фактов. В том числе преобразование «сцен реального мира» происходит в соответствии со стандартизированными представлениями, соответствующими типовым ситуациям, типовому набору характеристик объектов (к ним относятся сценарии, фреймы, схемы и т. д.)

По мнению В.3. Демьянкова [4], дискурс представляет собой объединение предложений или их фрагментов, а содержание дискурса концентрируется вокруг некоторого «опорного» концепта, который называ- 
ется «топиком дискурса», или «дискурсным топиком». Отдельные предложения - это компоненты дискурса, логическое содержание которых называется пропозициями. Пропозиции в свою очередь связаны между собой логическими отношениями (конъюнкции, дизъюнкции, «если то» и т. п.). «Понимая дискурс, интерпретатор компонует элементарные пропозиции в общее значение, помещая новую информацию, содержащуюся в очередном интерпретируемом предложении, в рамки уже полученной промежуточной, или предварительной интерпретации, то есть устанавливает различные связи внутри текста» [4].

В ходе интерпретации воссоздается мысленный мир, в котором, по презумпции интерпретатора, автор конструировал дискурс и в котором описываются реальное или нереальное положение дел. При этом анализ дискурса предполагает наличие языкового инструментария, при котором исследователь обращается не только к собственным лингвистическим знаниям, но также и общему фоновому знанию о реальном мире, поскольку в процессах понимания и порождения речи взаимодействуют все базы данных, хранящиеся в когнитивном аппарате человека. В основном анализу подвергаются не отдельные слова, а более крупные объединения (предложения или даже целые тексты), так как известно, что трансляция смысла ведется с помощью именно текстов. Именно поэтому текст стал объектом исследования отдельного направления языкознания, лингвистики текста, которое стремится выйти за рамки предложения. Дискурс может члениться на высказывания, в то время как существуют другие объединения, которые складываются из последовательных предложений, например, текст.

Итак, текст - это основная единица коммуникации, явление реального мира, обладающее референцией, или соотнесенностью с определенной ситуацией; текст отражает реальные ситуации общения с помощью языкового инструментария. Это означает, что текст включает два основных семантических маркера: а) текст есть некий «артефакт», т. е. не создан природой, а является продуктом человеческой деятельности, б) существует связность элементов внутри текста.

Будучи произведением речемыслительного процесса, текст обладает завершенностью, которая актуализируется в виде письменного документа, состоящего из названия и так называемых сверхфразовых единств, сопряженными с лексическими, грамматическими, стилистическими параметрами всего речевого построения, а также имеющего коммуникативную и прагматическую направленность. Текст как результат обработанной речи (в отличие от спонтанных речевых текстов), манифестирует себя в качестве источника хранения и передачи информации, связанной с лингвистическими, психическими, социальными, историческими, культурными и т. п. параметрами транслируемых структур. 
Теун ван Дейк разграничивает дискурс и текст: «дискурс - это понятие, касающееся речи, актуального речевого действия, тогда как текст - это понятие касающееся системы языка или формальных лингвистических знаний, лингвистической компетентности» [3].

В отличие от дискурса текст является реальным, физическим, материальным, «площадь, заполненная языковыми графическими формами и потому позволяющее самого разного рода операции с ним - можно вернуться к началу или к середине, заглянуть в его конец, можно переставить... строчки стихов, можно, как на компьютере, править готовый текст» [1: 23]. При этом О.В. Александрова и Е.С. Кубрякова уточняют, что дискурс - не может быть материальной субстанцией, а представляет собой «пространство времени, заполненное произнесением речевого произведения или же заполняемое его созданием». Рассматривая терминологический инструментарий когнитивных наук, О. В. Александрова и Е. С. Кубрякова [7: 194] неоднократно отмечают, что как тексты, так и дискурсы отражают не только уже постигнутое и достигнутое человеком, но выступают как субстанции, создающие новые миры. При этом текст рассматривается уже как готовая данность, с присущей ей завершенностью, конечностью результата, в то время как дискурс должен рассматриваться как процесс создания текстов. Таким образом, можно предположить, что дискурс является своего рода моделирующей структурой, в которой сосуществуют как фрагменты отраженной реальной действительности, так и возможных потенциальных миров.

Итак, дискурс - это процессуальное, динамичное явление, посредством которого осуществляется процесс синхронизированного порождения текста и его восприятия, поэтому оказывает непосредственное влияния на мыслительные процессы, постоянно изменяя и обновляя уже имеющуюся базу ментальных репрезентаций. Восприятие действительности на универсальном уровне осуществляется посредством ментальных моделей, которые являются хранилищем опыта и знаний человечества. Ментальные пространства создаются посредством «строителей» пространства (spacebuilders) [7: 194], которые участвуют в построении новых пространств дискурса или отсылают к уже существующим в нем пространствам. Примерами «строителей» Е.С. Кубрякова и О.В. Александрова называют наречия, предложные конструкции, различные частицы и т. д.

Следовательно, анализ дискурса во многом опирается на исследование ментальных моделей, которые в свою очередь определяют отбор коммуникативной информации для построения семантических структур. Ментальные пространства, пресуппозиции, умозаключения являются основными элементами анализа дискурса. В отличие от текста 
особенность дискурса состоит в стратегическом оперировании ментальными моделями для порождения самого текста.

Исходя из мнения о том, что текст является материальной данностью, обладающей завершенностью, конечностью построения и восприятия, а дискурс воспринимается как процесс порождения речевого произведения, отражающий как реальную действительность в режиме online, так и создающий фрагменты потенциальной действительности, соответственно, можно предположить, что из вышеуказанных моделей текста первая являет собой собственно текст, вторая - приближена к дискурсу, а третья - объединяет собой и текст, и дискурс. Подобные таксономические отношения приводят нас к такому пониманию текстовых категорий, при котором текст, как уже отмечалось, выходит за рамки предложения, т. е. состоит из совокупности предложений, состоящих между собой в определенной связи. При этом проблема связности текста играет далеко не последнюю роль.

Выясняется, что текстовые категории и дискурс взаимосвязаны, причем связь их осуществляется не только на лингвистическом (структурно-семантическом), но и на экстралингвистическом уровне, который как символьная проекция объединяет коммуникативную и когнитивную деятельность. Фиксация результатов сенсомоторного опыта в виде текстовых категорий не есть конечная стадия его отражения, поэтому дискурс как категория текущего сознания существует помимо текста, т. е. сверх или вне текста для порождения и создания новых возможных миров.

Итак, дискурс может рассматриваться как процесс (вербализованная речемыслительная деятельность) и как результат (фиксированный текст), а также в этих двух аспектах одновременно.

Поскольку дискурс является результатом взаимодействия с социумом, при исследовании дискурса выявляется его роль в формировании мнения адресата, а также контроле над мнением адресата. С одной стороны, исследование дискурса направлено на изучение прагматической ситуации, к которой он обращен - тем самым выясняется коммуникативная адекватность дискурса и его импликации. С другой стороны, оно нацелено на раскрытие стратегий его понимания в тех или других условиях адресатом и путей достижения целей адресата.

Исследования дискурса проводятся в режиме обработки языкового знания, при этом исследователь обращается не только к собственным лингвистическим знаниям, но также и к знанию о реальном мире, поскольку в процессе понимания и порождения речи активизируются все базы данных, хранящиеся в когнитивном аппарате человека.

Таким образом, дискурс представляет собой не просто вербальную манифестацию субъекта, но также является показателем того, что этот субъект мыслит, познает и сообщает об этом. Дискурс может понимать- 
ся как внешнее пространство времени, или сеть, в которой размещаются события физического знака.

Дискурс - это систематическое устройство для обработки языковой мысли, а также эмпирического опыта, в котором укладывается система категорий прошлого и будущего, существующего и возможного миров с уже пережитым и идеальным стечением обстоятельств, правилами игры и прочими установками. Однако, нет окончательного или вневременного дискурса так же, как не может существовать бесконечного дискурса, потому что формация дискурса не образует бесконечно повторяющейся совокупности высказываний, а ограничена условиями существования. Дискурс не обладает исторической или риторической общностью, он скорее конституируется определенным ограниченным числом высказываний, возникших в и воплощенных в определенной точке времени.

Следовательно, дискурс - это результат мыслительной и языковой обработки эмпирического опыта, воплощенного в определенной пространственно-временной обстановке посредством пропозиций.

$$
\text { Литература }
$$

1. Александрова О. В., Кубрякова Е. С. Виды пространств текста и дискурса // Категоризация мира: пространство и время. Материалы научной конференции. Под ред. проф. Е. С. Кубряковой, проф. О. В. Александровой. М.: Диалог-МГУ, 1997. С. 15-25.

2. Арутюнова Н. Д. Дискурс // Лингвистический энциклопедический словарь. М., 1990. C. $136-137$

3. Ван Дейк T. A. (1998). К определению дискурса. [WWW-документ] URL http://www.nsu.ru/psych/internet/bits/vandijk2.html

4. Демьянков В. 3. Политический дискурс как предмет политологической филологии [WWW-документ] URL http://www.nsu.ru/psych/internet/bits/ vandijk2.html

5. Квадратура смысла: Французская школа анализа дискурса. М.: ОАО ИГ «Прогресс», 2002. $-416 \mathrm{c}$

6. Красных В. В. «Свой» среди «чужих»: миф или реальность? М.: ИТДГК «Гнозис», 2003. -375 c.

7. Кубрякова E. C., Александрова O. В. О контурах новой парадигмы знания в лингвистике // Структура и семантика художественного текста. Доклады VII Международной конференции М.: 1999. С. 186-197.

8. Менджерицкая Е. О. Термин «дискурс» в современной зарубежной лингвистике // Лингвокогнитивные проблемы межкультурной коммуникации. М., 1997. С. 130-133.

9. Ревзина О. Г. Язык и дискурс // Вестник Московского университета. 1999, № 1. C. 25-34.

10. Руднев Ю. Концепция дискурса как элемента литературоведческого метаязыка [WWW-документ] URL http://www.nsu.ru/psych/ internet/bits/vandijk2.html

11. Фундаментальные направления современной американской лингвистики. - М., 1997.

12. Фуко М. Археология знания. Ника-Киев, 1996.

13. Harris Z. S. Discourse analysis // Language, 1952. 


\section{Языковая норма в постсоветской социокультурной ситуации}

(C) кандидат филологических наук Г. Ю. Никипореи-Такигава, 2004

Языковая норма - «совокупность правил выбора и употребления языковых средств в данном обществе в данную эпоху». Э. Косэриу предложил разграничивать два смысла понятия норма: в широком смысле норма соответствует не тому, что «можно сказать», а тому, что уже «сказано» и что по традиции «говорится» в рассматриваемом обществе. В узком смысле «норма» - это результат целенаправленной деятельности общества по отбору и фиксации определённых языковых средств в качестве образцовых, рекомендуемых к употреблению» ${ }^{2}$. Нас в данной статье интересует языковая норма (ЯН) в узком понимании, которая характеризуется следующим набором признаков:

1. ЯН существует в подсистеме литературного языка.

2. ЯН едина.

3. ЯН консервативна.

4. ЯН культивируется.

5. ЯН кодифицируется.

Несмотря на наличие нормы в широком смысле в диалектах, жаргоне и других подсистемах языка, языковая норма в узком понимании связана только с литературным языком, который противопоставляется другим подсистемам языка как кодифицируемый, нормированный.

В наши дни языковая ситуация продолжает развиваться по пути возрастания влияния СМИ на русский язык как систему и на языковую компетенцию среднего носителя русского языка.

«В процессе речевых контактов «говоримая» и слышимая речь явно преобладает над речью письменной. По данным исследований, в среднем на чтение мы отводим 16 процентов суточного бодрствования, на восприятие звучащей речи - 45 процентов, на говорение - 30 процентов, на письмо - 9 процентов. Иными словами, звучащая речь (в значительной своей части разговорная) в количественном отношении втрое «влиятельнее» речи письменной» ${ }^{3}$.

Завоевание технического прогресса и либерализации общественного сознания - современные устные СМИ, способствуют возрастанию

\footnotetext{
${ }_{1}^{1}$ Беликов В. И., Крысин Л. П. Социолингвистика. М., 2001. С.39.

${ }^{2}$ Косэриу Э. Синхрония, диахрония и история // Новое в лингвистике. Вып.3. М., 1960. C. 175 .

з Розенталь Д. Э. Практическая стилистика русского языка. М., 1998. С.38.
} 
пропорции звучащей речи. Результаты многочисленных социологических опросов и статистические данные свидетельствуют о том, что главным видом досуга среднего россиянина является телевизор. Устные СМИ вытесняют чтение как вид речевой деятельности, успешно конкурируя с печатными СМИ, заменяя чтение художественной литературы.

Печатное слово, художественная литература в советское время выполняла роль языкового ориентира, на основе которого и при помощи которого формировались представления о языковой норме и культуре речи. В постсоветской социолингвистической ситуации таким ориентиром становится устное слово, а его образцом язык устных СМИ.

Лингвисты всесторонне исследуют СМИ, и в наших оценках языка СМИ соседствуют два полюса. С одной стороны, как явно положительное явление, отмечается большая свобода в выборе средств выражения, отсутствие скованности и зажатости, продвижение свободной стихии разговорной речи в язык СМИ. С другой стороны, отмечается негативное влияние свободного и демократичного языка СМИ на языковые вкусы современников, языковую компетенцию, на языковую норму и культуру речи.

Постараемся избежать критики. Это не продуктивный путь, так как не видно предпосылок для того, чтобы язык СМИ вернулся к почти идеальному с точки зрения соблюдения языковой нормы состоянию, которое его отличало в эпоху тоталитаризма. Языковая ситуация складывается так, что влияние СМИ на язык и общество будет возрастать, а язык СМИ становится всё свободнее и демократичнее, взяв на себя функцию единственного или самого авторитетного языкового ориентиpa.

Попробуем проанализировать язык СМИ в ином ракурсе - как новый языковой ориентир, культивирующий новую языковую норму.

Выделим признаки, характеризующие язык современных СМИ:

1. Язык СМИ не принадлежит подсистеме литературного языка.

С начала девяностых годов в язык СМИ стали активно проникать элементы некодифицированных подсистем русского языка: просторечие, жаргонизмы и арго: “Y”: Лето у поп-звёзд - пора гастрольного чёса по городам... В чём секрет их успешности? - Е.Ф.: Понятно, что «Руки вверх!» - это конченая попса, но публика на них ходит, потому что в своём формате это мало-мальски талантливо сделано... По этой же причине в прошлом году они слили свою же шведскую группу «Афродит» с очень сильной песней... («Утро на НТВ» 26.08.03.).

Щас они объединятся с такими амбициями... Вот, к доктору не ходи, сейчас начнётся массовое вооружение иракцев для того, чтобы они истребляли других иракиев. То есть, насвинячили, разворошили улей - а теперь они хотят смотаться... Однако есть ещё более общий урок. 
Союзники Соединённых Штатов теперь должны почувствовать, с какими вызовами они столкнутся... («Однако» 19.11.03).

Американский госкомстат сообщил тут об экономическом росте больше 7 прочентов, а рынок прореагировал падением котировок. Но того, что произошло во вторник - маски-шоу на Уолл-стрите, - это вообще-то как-то будит воображение. А вот представьте себе, если бы у нас в Москве на ММВБ люди в масках свинтили 48 брокеров? То есть вы понимаете, на что мы намекаем... («Однако» 20.11.2003). ${ }^{4}$

Часто приглушённо, но довольно явственно звучит в эфире и обсценная лексика.

В стилистическом отношении в настоящее время мы имеем дело с СМИ, которые максимально приблизились по форме к бытовому общению, настойчиво имитируют сниженную бытовую коммуникацию.

Помимо высокого содержания не кодифицированной лексики для СМИ характерно нарушение существующей языковой нормы, так как современные СМИ ориентированы на спонтанное говорение. Говорение и письмо - суть разные по степени ответственности и по возможностям самоконтроля виды речевой деятельности, игнорирование процесса предварительной записи читаемых текстов неизбежно продуцирует ошибки и неточности.

2. Язык СМИ вместо единой языковой нормы предлагает большую вариативность и свободу выбора.

Чётких ориентиров СМИ не даёт, законодателем, языковым авторитетом становится популярный ведущий или политик. «Так можно, я вчера по телевизору слышал. Так можно, все так говорят. Так можно, так сам такой-то говорит», - аргументация для оправдания ошибки. «Как хочу, так и говорю», «Как хочу, так и пишу», - это новая языковая норма.

Устные СМИ расширили круг говорящих публично. Скудные по содержанию, безнадёжно идеологизированные советские радио и телевидение демонстрировали высокую культуру речи в исполнении известных поимённо профессиональных дикторов, зачитывающих тексты, тщательно выверенные профессиональными редакторами. Важную роль играла и система материального наказания за допущенные ошибки. Ликвидация института дикторов и литературных редакторов, ставка на содержание, создание новой неопределённой профессии ведущего-

${ }^{4}$ В качестве иллюстрации предлагаются не отдельные примеры, а тексты, что по-

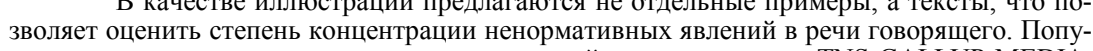
лярность передач определялась при помощи рейтингов компании TNS GALLUP MEDIA. Рейтинги помогают очертить круг телевизионных предпочтений и выбрать те передачи, которые в большей степени влияют на языковую компетенцию среднестатистического россиянина. 
диктора-комментатора привели к тому, что СМИ предлагают в качестве образца не единую языковую норму и культуру речи, а индивидуальную. Актуальное требование говорить «без бумажки» породило новую генерацию журналистов - самоуверенно несущих в массы собственные представления о культуре речи и языковой норме.

3. Язык СМИ не консервативен, немедленно реагирует на узус и языковую моду.

Последнее десятилетие в моде американизмы. «Если с 1960-1985 в русском языке было зафиксировано около 9000 новых слов, то с 1984 прибывало каждый год по 2 тысячи» (из доклада Л. А. Вербицкой на Х Конгрессе МАПРЯЛ). Долгие годы изоляции СССР от внешнего мира сменились эпохой открытых границ и калькированием стиля жизни, чужой культуры и языка в ущерб красоте и точности русской речи, заимствования стали социально престижным слоем лексики.

Модно придать речи некоторый флёр ироничности. Иронией, злоязычием, ёрничаньем прикрывается неуверенность в словах и мыслях, нередко отсутствие слов в индивидуальном словаре, мыслей и чувства юмора, так как тонко пошутить труднее, чем грубо съязвить. Того же происхождения модное как бbl. Его употребление продиктовано желанием «говорить красиво» (ложно понятое представление о культуре речи) и неопределённо. Такое стремление снять всякую ответственность за слова, неуверенность в словах и мыслях характеризуют современное духовное состояние общества.

Явления языковой моды широко представлены в языке СМИ. Сейчас не в моде роскошь. Украшения стали более микшированные, более гламурные... И, видите, они как бы висят, гнутся. («Утро на НТВ» 27.02.04.) На церемонии вручения «Серебряной галоши» 1.01 .04 года ведущие выражали восторг и удивление при помощи восклицания вау (yay). Многократно повторяемое в течение полутора часов вау подхватывал зал, сначала со смехом, потом привычно. Тем самым наглядно демонстрируя модель воздействия СМИ на аудиторию.

4. Язык СМИ культивируется.

Мы переживаем «словарный бум», лексикографы спешат отразить быстро меняющийся узус. Отрадно, что любое услышанное в СМИ слово можно найти в словарях. Хотя, помня определение А. М. Пешковского (языковая норма - «это то, что было вчера, отчасти то, что есть сегодня, но отнюдь не то, что будет завтра» ${ }^{5}$ ), можно было бы так не торопиться. Следует помнить и о том, что фиксация продле-

${ }^{5}$ Пешковский А. М. Избранные труды. М., 1959. С.54-55. 
вает жизнь слову, в том числе устаревающим на этапе печатания явлениям языковой моды.

Язык СМИ пропагандируется. СМИ обладают уникальной возможностью тиражирования и мощным пропагандистским эффектом. Наряду со способностью внедрять в массы идеи, СМИ пропагандируют стиль, темп речи, новую лексику. Язык СМИ престижен. В той же степени, насколько популярны герои экрана, престижен их язык.

Пока языку СМИ не обучают в школе. Учебники написаны красивым и правильным русским языком, программы по литературе призваны воспитывать литературный вкус и культуру речи. Однако школа не может противостоять влиянию на речь подрастающего поколения со стороны СМИ, лингвисты не определяют развитие узуса, если язык СМИ уйдёт ещё дальше от языка учебников по родной речи, придётся изменить учебники.

Суммируя изложенное, можно представить язык СМИ как новый языковой ориентир, культивирующий новую языковую норму (НЯН) со следующим набором признаков:

1. НЯН существует во всех подсистемах языка. (Или снимает деление языка на подсистемы.)

2. НЯН не едина.

3. НЯН не консервативна.

4. НЯН культивируется.

5. НЯН кодифицируется.

Такой набор признаков размывает понятие «языковая норма», поэтому не может удовлетворить лингвистов. Лингвистическое сообщество предпринимает попытки убедить общественность в необходимости соблюдения языковой нормы и культуры речи в СМИ.

Следует учитывать, однако, что языковая норма - это инструмент языковой политики государства, кодификация и культивирование задачи не сугубо лингвистические. Это задачи государственного масштаба, направление языковой политики, которое зависит от осознания политиками и государственными деятелями роли и места языка в становлении и укреплении национального самосознания.

В эпоху тоталитаризма строго соблюдаемая единая языковая норма способствовала консолидации общества. Новая языковая норма с новым набором признаков может служить идеальным инструментом языковой политики государства, направленной на дезинтеграцию общества.

Не будем утверждать, что политика нашего государства именно такова. Может быть, у нашего государства нет языковой политики или государство не понимает, что языковая политика - важная часть госу- 
дарственной политики. Тогда следует думать, что язык СМИ развивается стихийно и культивирование языка СМИ происходит бессознательно.

Если же сегодняшней задачей языковой политики государства является разрушение языковой нормы и целостности языка, превращение языка в инструмент дезинтеграции общества, то современные СМИ с этой задачей успешно справляются. 


\title{
Единицы кодов культуры: проблемы семантики
}

\author{
(C) доктор филологических наук Д. Б. Гудков, 2004
}

Те или иные объекты окружающего нас мира (как природные, так и артефакты), помимо выполнения своих прямых функций, обретают еще и функцию знаковую, оказываются способными нести некие добавочные значения. Имена, называющие подобные объекты, образуют связанные друг с другом вторичные семиотические системы, которые мы называем кодами (соматическим, зооморфным, природно-ландшафтным и др.) национальной культуры ${ }^{1}$.

Единицы, являющиеся составляющими этих кодов, наделяются определенными культурными значениями, часть из которых присутствует в «светлой зоне» сознания представителей той или иной культуры, другие же не осознаются, присутствуют имплицитно, представляя собой своеобразные «лакуны», их экспликация является результатом лингвокультурологического анализа.

«Код культуры понимается как "сетка", которую культура "набрасывает" на окружающий мир, членит, категоризует, структурирует и оценивает его. Коды культуры соотносятся с древнейшими архетипическими представлениями человека. Собственно говоря, коды культуры эти представления и "кодируют"» [Красных 2002, с. 232]. Коды культуры занимают центральное положение в национальном культурном пространстве, являются структурообразующими элементами последнего. Сама культура при этом выступает как совокупность различных кодов. Проблема соотношения этих кодов подробно рассматривалась Н.И. Толстым на примере обряда и ритуала: «...Культура многоязычна в семиотическом смысле этого слова и нередко пользуется в одном тексте несколькими языками. В этом случае $<\ldots>$ под текстом понимается не последовательность написанных или произнесенных слов, а некая последовательность действий, и обращения к предметам, имеющим символический смысл, и связанная с ними речевая последовательность. Считая, например, обряд таким текстом, выраженным семиотическим языком культуры, мы выделяем в нем три формы, три кода или три стороны языка - вербальную (словесную - слова), реальную (предметную - предметы, вещи) и акциональную (действенную - действия). В

${ }^{1}$ Подобное понимание кодов культуры, как и дальнейшие размышления о семантике относящихся к ним единиц, во многом обусловлены нашей работой над лингвокультурологическим словарем русских фразеологизмов под редакцией В. Н. Телия и опираются на положения выработанные коллективом создателей названного словаря. При этом, конечно, автор несет полную ответственность за выдвигаемые тезисы. 
обряде, ритуале и некоторых других культурных действиях и манифестациях единицы этих трех языков (кодов), а в общем «слова» единого семиотического языка часто выступают как синонимы, потому они нередко взаимозаменяемы, а часть их может редуцироваться» [Толстой, c. 23].

Мы полагаем, что выделение этих трех кодов (вербального, реального и акционального) возможно не только в обряде и ритуале, но вообще в поле культуры как таковом. При этом хотелось бы сделать ряд замечаний, касающихся нашего подхода к данной теме.

Во-первых, под чрезвычайно широким термином «реальный код культуры» понимается совокупность самых разных кодов, каждый из которых образует собственной «семантическое поле»: природно-ландшафтный (лес, море, гора, вода, песок и др.), архитектурно-домообустроительный (дверь, порог, крыша и т. д.), вещный (нож, рубаха, нитка, карман и т. д.), сюда же могут быть, вероятно, отнесены зооморфный, в какой-то степени соматический и другие коды. Мы в дальнейшем каждый из этих кодов будем рассматривать дифференцированно.

Во-вторых, единицы как реального, так и акционального кода культуры, могут вербализоваться, получить свое именование, иными словами, стать составляющими вербального кода. Именно это и позволяет нам рассматривать вербальный код культуры как базовый, основной и сосредоточить свое внимание именно на нем. Сказанное выше отнюдь не означает, что мы настаиваем на эквивалентной переводимости иных кодов в вербальный. В некоторых случаях это возможно с весьма высокой (хотя и не абсолютной степенью адекватности. В качестве примера можно указать на активно развивающийся в русском лингво-культурном сообществе «автомобильный» код, в котором машина становится не только (часто и не столько) «средством передвижения», но и призвана манифестировать определенный имидж ее владельца - помимо социально престижных, дорогих, «крутых» и противопоставленных им непристижных, дешевых, «совковых» автомобилей, существует их условная градация на «солидные» / «молодежные», «мужские» / «дамские» и др. Этот код нашел свое яркое вербальное воплощение, скажем, в обширной серии анекдотов о столкновении «Запорожца» с «Мерседесом», в которых названия марок автомобилей выступают как знаки социального статуса их владельцев, не требующего никакой иной экспликации.

В других случаях подобная вербализация практически невозможна, во всяком случае, весьма и весьма затруднительна. К примеру, один из моих знакомых, живущий и занимающийся бизнесом в Канаде, рассказывал, что в деловых кругах Торонто (возможно, не только там) помимо всего прочего, весьма важным в формировании впечатления о партнере по коммуникации в этой сфере является его галстук (цвет, форма, как 
завязан и т. д.). С помощью данной детали одежды, оказывается, можно сообщать окружающим о своем характере, методах работы, деловых и прочих пристрастиях (было перечислено свыше десятка различных значений). Совершенно очевидно, что подобный «галстучный» код весьма сложно сколько-нибудь адекватно вербализовать.

Мы в нашем исследовании сосредоточим свое внимание исключительно на единицах языка, являющихся носителями особых значений, детерминированных тем культурным кодом, которому эти единицы принадлежат. Скажем, рассматривая соматический и иные коды культуры, мы имеем в виду разные «подвиды» вербального кода. Иными словами, анализируя единицы, скажем, природно-ландшафтного кода, мы изучаем не собственно совокупность определенных объектов окружающего мира, а совокупность имен этих объектов; говоря, например, о лесе как единице этого кода, мы говорим не о лесе как таковом, а о слове лес (о соотношении имени и его референта в пределах культурного кода подробнее будет сказано ниже).

Теперь необходимо остановиться на вопросе о соотношении интересующих нас имен как единиц естественного языка и единиц культурного кода. Интересующие нас имена оказываются включенными в две семиотические системы: систему естественного языка как слова этого языка и в систему соматического кода, в которой они наделяются особыми значениями, связанными с общеязыковыми, но существенно отличающимися от них. Р. Барт, считавший, что «в человеческом обществе на базе первичной системы, образуемой естественным языком, постоянно возникают системы первичных смыслов» [Барт 75, с. 11], обращал внимание на специфические знаки, принадлежащие сразу двум семиологическим системам: «...Знак (т. е. результат ассоциации концепта и акустического образа) первой системы становится всего лишь означающим во второй системе» [Барт 89, с. 78]. Мы в дальнейшем будем рассматривать имена, принадлежащие телесному коду культуры, как элементы вторичной семиотической системы, образуемой этим кодом, знаки второго уровня, отрешаясь по возможности от их общеязыковых значений, которыми они обладают как знаки первого уровня. Речь идет не об «индивидуальных» коннотациях слова, а именно о системе взаимосвязанных символических значений, образующих особый тезаурус.

Будем условно называть естественный язык первой семиологической (семиотической) системой, а культурный код - второй семиологической системой. Конечно, и сам культурный код принадлежит естественному языку в широком смысле этого слова, но он образует несколько иную систему значений, отличных от тех, которые описываются в традиционных словарях и грамматиках. Чтобы убедиться в этом, доста- 
точно сопоставить семантику таких, скажем, единиц, как кровь и горло в «естественном языке» и в соматическом коде культуры. Согласно словарю С.И. Ожегова, кровью называется «обращающаяся в организме красная жидкость, обеспечивающая питание и обмен веществ всех клеток тела» [Ожегов, с. 282], а горлом - «1. передняя часть шеи, заключающая в себе начало пищевода и дыхательных путей; 2. полость позади рта (зев, глотка и гортань); 3. верхняя суженная часть сосуда; 4. узкий выход из залива, устье» [Ожегов, с. 129]. При этом никак не указывается, что кровь символизирует, к примеру, жизненную энергию человека, оказывается знаком родственной и духовной близости, а горло метонимически связывается с дыханием, которое, в свою очередь, метафорически связывается с представлением о свободе / несвободе (ср.: держать за горло, наступать на горло) $)^{2}$.

Итак, имена, принадлежащие тому или иному коду культуры, обладают, помимо общеязыкового, еще и особым значением как знаки вторичной семиотической системы, причем значение это отнюдь не является ситуативно обусловленным, но закреплено за соответствующей единицей языка. «Классические» толковые словари, как правило, не описывают эти значения, игнорируя их, что делает необходимым и актуальным выявление этих значений и введение подобных описаний в лексикографическую практику. Решение поставленных задач позволит перейти от абстрактного теоретизирования к практическому словарному описанию культурных кодов. Это же, в свою очередь, даст возможность приблизиться к решению таких фундаментальных для современной гуманитарной науки задач, как описание языковой картины миры, выявление особенностей национального менталитета и национального мировидения, определение особенностей национально специфического воплощения универсальных инвариантных представлений о мире и др.

При всем этом нас интересует бытование той или иной единицы в языковом сознании представителей современного русского лингвокультурного сообщества, данные же этимологии (в широком понимании) привлекаются лишь как вспомогательные. Поясним сказанное только одним примером. Скажем, кровь выступает как носитель генетически наследуемых качеств человека, объединяя людей, одной расы, нации, рода, качество крови определяет и другие качества человека. Именно в это «поле» включается семантика слова кровь в таком фразеологизме, как голубая кровь, этимологически являющемся калькой с испанского la sangre azul. Как утверждают А.М. Мелерович и В.М. Мокиенко, «первоначально этот оборот характеризовал аристократические семьи испанской провинции Кастильи, которые гордились «чистотой»

\footnotetext{
щей работы.

2 Подробнее о семантике данных единиц см. в соответствующих разделах настоя-
} 42 
своей расы, то есть не заключали смешанных браков с маврами и другими людьми со смуглой кожей; у белокожих людей вены видны отчетливее; поэтому их кровь казалась голубой» [Мелерович, Мокиенко, c. 348]. Данная этимология, на наш взгляд, для современного языкового сознания носителя русского языка является неактуальной. Как показывает наш пилотажный опрос, внутренняя форма рассматриваемого фразеологизма толкуется примерно так: «особые свойства крови аристократов, которая даже цветом отличается от крови обычных людей».

Ставя своей целью описания значения интересующих нас вербальных единиц, мы с необходимостью должны остановиться на вопросе о том, что же за значение собираемся мы описывать, каков его семантический статус, что неизбежно потребует от нас рассмотрения некоторых базовых проблем семантической теории. Мы остановимся на своем понимании таких неоднозначно толкуемых в современной лингвистике понятий, как символ, значение, смысл, коннотация и ассоциация. Подчеркнем, что настоящая работа никоим образом не претендует на сколько-нибудь полный анализ указанных вопросов, в ней лишь в контексте современных исследований аргументируется обоснованность предлагаемого подхода, вовсе не претендующего на исключительность и монополию на истину.

Об особой семантике некоторых имен, принадлежащих сразу двум семиотическим системам, уже говорилось в научной литературе. К. Леви-Стросс, называя подобные единицы мифемами, указывал: «В сказке король никогда не бывает просто королем, а пастушка пастушкой. < ..> Разумеется, мифемы - это тоже слова, но это слова с двойным значением, слова слов» [Леви-Стросс, с. 428]. «Обыденному» значению слова оказывается противопоставлено его «мифологическое» или «символическое» значение. Впрочем, мы неоднократно слышали возражения, что вести в данном случае речь о каком-то особом значении не имеет смысла, достаточно сказать о коннотации и на этом можно ставить точку. Заметим, что понятие коннотация в последнее время превратилось в универсальную отмычку, позволяющую легко открывать двери, замкнутые доселе для пытливого научного ума, в нечто, дающее возможность объяснить все то, что традиционному объяснению не поддается. Между тем сам этот термин понимается настолько по-разному и охватывает в различных толкованиях столь разнородные объекты, что потерял главное качество научного термина - однозначность и определенность, став без ясного толкования того, что подразумевает под ним тот или иной автор, почти асемантичным. Сказанное заставляет подробнее остановиться на том, что же будет пониматься под коннотацией в настоящей работе. 
Приведем сначала ставшее почти классическим определение Ю.Д. Апресяна, который называет коннотациями лексемы «несущественные, но устойчивые признаки выражаемого ею понятия, которые воплощают принятую в данном языковом коллективе оценку соответствующего предмета или факта действительности; они не входят непосредственно в лексическое значение слова и не являются следствиями или выводами из него» [Апресян, с. 159]. Согласно данному определению, коннотации, с одной стороны, не противопоставляются понятийному содержанию слова, а с другой - не относятся к лексическому значению последнего. При этом «в настоящее время в отечественной лингвистике укрепилось представление о лексическом значении как о многокомпонентном семантическом целом; как правило, в его структуре выделяют в качестве обязательных денотативный и сигнификативный компоненты значения, а в качестве факультативных - коннотативный (или эмотивный), этнокультурный и структурный (парадигматический и синтагматический) компоненты» [Лукашевич, с. 56-57]. Лексическое значение может пониматься «как бесконечно сложная, избыточная структура, включающая в себя не только понятийное содержание, но и весь запас лингвистических и экстралингвистических сведений, ассоциаций, смутных как будто бы априорных представлений и всех «добавочных смыслов», называемых коннотациями» [Скляревская, с. 64].

Последнее из приведенных определений объединяет под коннотацией практически все элементы значения лексемы, не относящиеся к ее понятийному содержанию. Нам представляется, что не имеет смысла столь широко понимать коннотацию, вероятно, совокупность всего, что не относится к понятийному содержанию слова следует называть каким-то иным термином, например, следуя за сторонниками лингвострановедческой теории слова, лексическим фоном: «Семантика слова не исчерпывается одним лишь лексическим понятием. Лексическое понятие восходит к классифицирующей и номинативной функциям языка, однако в слове имеется и семантический компонент, который соответствует кумулятивной, накопительной функции. <..> Пусть вся совокупность непонятийных семантических долей, относящихся к слову, называется его лексическим фоном. <..> Не следует думать, что лексический фон - это индивидуальное достояние отдельного человека, <..> лексический фон, как и лексическое понятие, как и само слово в двух своих планах, - это принадлежность языка, явление массового, общественного, т.е. языкового сознания» [Верещагин, Костомаров, с. 56-58].

В.Н. Телия, являющаяся автором соответствующей статьи в энциклопедическом словаре «Языкознание», называет коннотацией «эмоциональную, оценочную или стилистическую окраску лексической единицы узуального $<\ldots>$ или окказионального характера; <..> в структуре 
коннотации ассоциативно-образный компонент выступает как основание оценочной квалификации» [Языкознание, с. 236]. Процитированный автор указывает, что коннотация может оказываться окказиональной, и сближает коннотацию и оценку. Нам ближе точка зрения И.М. Кобозевой, отказывающей коннотации в окказиональности: «Коннотации отличаются от прочих видов прагматической информации тем, что они включают в себя отсылку не к индивидуальному пользователю знака - говорящему, а к языковому коллективу» [Кобозева 2000, с. 92]. При этом цитируемый автор предлагает отличать коннотации от эмоционально-оценочных компонентов значения слова, отражающих индивидуальное отношение говорящего к обозначаемому объекту [Кобозева 2000, c. 88-89].

Попробуем теперь дать предварительную формулировку собственного понимания коннотации, которое уточним в дальнейшем. Мы называем коннотацией набор дифференциальных признаков слова, не относящихся к его сигнификации, то есть не препятствующих обозначению этим словом объекта, указанных признаков лишенного, но обусловливающих употребление этого имени в характеризующей функции, позволяющих ему выступать в позиции семантического предиката. Заметим, что коннотативный элемент значения может оказываться экспрессивным и оценочным, но это вовсе не является обязательным. Рассмотрим такое высказывание: $N$ женат, но в душе он холостяк. Вряд ли оно может быть признано аксиологическим суждением, весьма сомнительным является и его экспрессивность.

Обратимся к еще одному примеру: Его тетка была ему настоящей матерью. Можно предположить, что употребляющий данное высказывание стремится дать объективную характеристику определенного положения вещей, а не выразить свое субъективное отношение к указанному факту, достаточно привести осложнение приведенного коннотативного употребления лексемы мать отрицательной оценкой: $K$ сожалению, именно тетка, женщина грубая, жестокая и корыстолюбивая, была ему настоящей матерью. Таким образом, коннотациями имени мать являются такие признаки, как забота о ребенке, его воспитание, доброта к нему и др. Такие понятийные семы, как кровное родство, даже женский пол (ср.: Старший брат стал ему настоящей матерью), при коннотативном употреблении слова могут оказываться несущественными.

Теперь остановимся на вопросе о соотношении коннотаций и ассоциаций. Для некоторых исследователей характерно сближение, а иногда и отождествление этих понятий. Так, И. М. Кобозева называет коннотациями «(семантические) ассоциации» и ссылается на Я. Бартиминского, понимающего под коннотациями «совокупность <..> закрепленных в 
культуре данного общества ассоциаций» [Кобозева 2000, с. 92]. Мы же полагаем необходимым различение коннотаций и ассоциаций.

Ассоциации могут быть как индивидуальными и окказиональными, так и закрепленными в определенном языковом коллективе ${ }^{3}$. Как уже говорилось выше, мы отрицаем индивидуальность и окказиональность коннотаций, поэтому не будем останавливаться на ассоциациях этого типа. Говоря же о предсказуемых ассоциациях, закрепленных в культуре лингво-культурного сообщества, мы выступаем против их отождествления с ассоциациями ${ }^{4}$.

Коннотации присущи лексической единице, входят в саму эту единицу, находятся внутри ее «границ», т. е. ингерентны ей, ассоциации же адгерентны лексической единице, находятся вне ее «границ», приписываются ей языковым коллективом. Подтвердим сказанное только двумя примерами. «Ассоциативный тезаурус русского языка» показывает, что наиболее частотной ассоциацией к слову памятник является имя собственное Пушкин ${ }^{5}$, но сомневаемся, что кто-либо решится утверждать, что это имя собственное является коннотацией указанного слова. Говоря о содержании лексемы немеи, можно отметить, что такие признаки, как аккуратность, педантичность, трудолюбие, не относясь к понятийному ядру имени, могут быть причислены к ее коннотациям. При этом вряд ли можно согласиться с тем, что такие абсолютно предсказуемые в русском лингво-культурном сообществе и весьма частотные, согласно "Ассоциативному тезаурусу русского языка», ассоциации к слову немеи, как фашист, фронт, война, могут быть отнесены к коннотациям данной единицы. Об этом же свидетельствуют и данные лингвистического эксперимента с псевдотавтологиями типа Немец есть немец (обратим внимание, что в первом случае имя употребляется денотативно, а во втором - коннотативно). Информанты, которых просили интерпретировать подобные высказывания, актуализировали в своих ответах именно указанные коннотации, а не те устойчивые предсказуемые ассоциации, которые были приведены выше [Кобозева 1995]. Итак, необходимо разграничивать ассоциации и коннотации, хотя некоторые предсказуемые ассоциации могут быть связанными с коннотативными семами.

Таким образом, мы рассматриваем коннотацию языковой единицы как закрепленные за этой единицей непонятийные дифференциальные признаки, стоящего за ней представления (вернее, совокупности пред-

\footnotetext{
${ }^{3}$ О национально стереотипизированных ассоциациях см. [Прохоров, с. 129 и след]; о национально культурной детерминированности векторов ассоциативных валентностей и о предсказуемых ассоциативных связях см. [Красных, с. 161 и след].

4 Далее мы излагаем положения, выработанные автором совместно с В. В. Красных и изложенные в [Гудков, Красных, 2001].

5 Заметим, что здесь возникает вопрос о связи коннотаций и ассоциаций с прототипами, но на нем мы позволим себе не останавливаться.
} 
ставлений). Полагаем, что можно, хотя и с достаточной степенью условности говорить о непонятийных дифференциальных признаках стоящего за именем представления, так как именно они в определенных случаях обусловливают возможность / невозможность номинации этим именем того или иного объекта. В качестве примера можно вспомнить фразу «Вы не мать!», брошенную в лицо советской разведчице малосимпатичным персонажем кинофильма «Семнадцать мгновений весны». Радистка Кэт была исключена гестаповцем из множества матерей именно на основании коннотаций лексемы мать. Если принять приведенное определение, то интересующее нас значение составляющих культурного кода является коннотативным, противопоставленным в нашем анализе «естественноязыковому» значению, которое условно можно назвать денотативным.

При этом представляется, что в данном случае мы имеем дело с особым типом коннотативного значения; его имеет смысл называть символическим в понимании, близком тому, которое вкладывает в это понятие О. Г. Пестова: «Под символическим значением нами понимается тип конвенционально обусловленного значения, образовавшегося на основании механизмов метафоризации и метонимизации, в котором наименование конкретного предмета выступает в качестве означающего для абстрактного значения» [Пестова, с. 92]. Сказанное заставляет нас остановиться на том, что́ же следует понимать под символическим значением, а это ставит нас перед проблемой символа как такового.

Проблема эта может быть отнесена к числу древнейших, идущих к нам от пифагорейцев через Платона и средневековых схоластов. В нашу задачу, конечно же, не входит ни даже краткое изложение истории вопроса, ни попытка классифицировать существующие точки зрения ${ }^{6}$. В лингвистике проблема символа неразрывно связана с проблемой языкового знака. Причем одни исследователи недифференцированно употребляют термины «символ» и «знак», другие же настаивают на разграничении этих понятий: «Символ отличает отношение аналогии между означаемым и означающим и их неадекватность (представление о христианстве «шире» представления о кресте). <...> В знаке отношение между составляющими является немотивированным и адекватным (не существует аналогии между словом «бык» и образом быка, который полностью исчерпывается соответствующим означающим)» [Барт 75, с. 129].

В своем разграничении понятий знака и символа мы следуем за А. Ф. Лосевым, который указывал: «Символ есть развернутый знак, но знак также является неразвернутым символом, его зародышем. <...> Для примитивного и элементарного понимания соотношения смысла вещи и самой вещи едва ли необходим термин «символ». <...> Символ

6 Это сделано, в частности, в ставшей почти классической монографии [Тодоров]. 
требует для себя не просто модели, но еще и порождающей модели. $<\ldots>$ Символ не просто обозначает бесконечное количество индивидуальностей, но $<\ldots>$ он есть также и закон их возникновения» [Лосев, c. 133-134]. Символ, как отмечал Ю. М. Лотман, способен «сохранять в свернутом виде исключительно обширные и значительные тексты» [Лотман, с. 148].

Ниже мы постараемся показать, что единицы культурного кода выступают именно как символы, сейчас же остановимся на центральном вопросе семантики - об отношении интересующих нас имен и их референтов.

Говоря об особенностях соотношения «означающее - означаемое» в рамках определенного культурного кода, заметим, что по этому параметру интересующие нас языковые единицы могут быть условно разделены на две группы. Как указывает В.Н. Телия, в одних «культурно значимая информация воплощается в денотативном аспекте значения (это слова, обозначающие реалии материальной культуры или же концепты культуры духовной и социальной)», в других «культурно значимая информация выражается в коннотативном аспекте значения» [Телия, с. 235]. Иными словами, в одном случае сам объект, на который указывает слово, оказывается наделен символической функцией, в другом - эту функцию выполняет само слово, а не та реалия, на которую оно указывает. Например, кровь наделяется сакрально-магической функцией. Ограничимся лишь несколькими примерами: в культах Кибелы и Митры кровь обладает очищающей силой, вспомним поиски Святого Грааля, чаши, в которую стекала кровь Христа, мистический интерес к крови фашистов (забота о «чистоте крови») и большевиков (от цвета их знамени до открытия вскоре после Октября Института крови, руководитель которого, видный партийный деятель Богданов, погиб, ставя на себе загадочный эксперимент по переливанию крови) и т. д., и т. п. Согласно древнейшим архетипическим представлениям, именно кровь является носителем жизненной силы, энергии жизни. Подобная символика находит отражение в значении имени кровь, ср., например, такие фразеологизмы, как смывать/смыть кровью, в крови, проливать / пролить кровь и др. Договор с дьяволом подписывается именно кровью. Позволим себе привести фрагмент известного стихотворения А. Галича «Еще раз о черте»:

“...И кому оно нужно это добро,

Если всем дорога - в золу...

Так давай же, бери, старина, перо

И вот здесь распишись в углу".

Тут черт потрогал мизинцем бровь

И придвинул ко мне флакон. 
И я спросил его: “Это кровь?”

"Чернила", - ответил он...

Сама ситуация из фантастического и метафизического переводится в земной, обыденный план, актуализируя представления не о потусторонних, а о вполне реальных, хорошо всем знакомых «демонах». Данный художественный эффект достигается путем замены магической, «сакральной» крови бытовыми, «профанными» чернилами.

Если же рассмотреть такую единицу соматического кода, как нос, то легко заметить, что нос как часть тела вовсе не связан с символикой «пограничного столба» между внутренним пространством человека и внешним для него пространством, не является сам по себе знаком пространственной близости. Этим значением обладает имя нос, а отнюдь не его референт, ср., например: под носом, из-под носа, нос(-ом) к носу.

Таким образом, различия между именами кровь и нос в их связи с означаемым представляются очевидными. Мы согласны с В.Н. Телия, которая говорит о необходимости «разграничивать функцию реалии и символическую функцию имени языкового знака» [Телия, с. 243]. Ведь «в отличие от собственно символов (когда носителем символической функции является предмет, артефакт или персона) роль языкового символа заключена в смене значения языковой сущности на функцию символическую; словозначение в этом случае награждается смыслом, указывающим не на собственный референт слова, а ассоциативно “замещает” некоторую идею» [Телия, с. 243].

Обратим внимание, что структура семантического поля, образуемого значениями знаков второго уровня, к которым мы относим единицы культурных кодов, изоморфна структуре семантических полей естественного языка, в котором эти же слова выступают как знаки первого уровня. Как и в естественном языке, можно выделять полисемичные и моносемичные имена. В определенных позициях единицы культурного кода могут выступать как прагматические эквиваленты, в других - противопоставляться друг другу, т. е. можно говорить о синонимии и антонимии этих единиц.

Подводя итоги, повторим, что имена, принадлежащие соматическому коду культуры, обладают, помимо общеязыкового, еще и особым символическим значением как знаки вторичной семиотической системы, причем значение это отнюдь не является ситуативно обусловленным, но закреплено за соответствующей единицей языка. «Классические» толковые словари, как правило, не описывают эти значения, игнорируя их, что делает необходимым и актуальным введение подобных описаний в лексикографическую практику. 
1. Апресян - Апресян Ю. Д. Коннотации как часть прагматики слова (лексикографический аспект) // Избр. труды. Т.ІІ. Интегральное описание языка и системная лексикография. М., 1995, с. 159.

2. Барт 75 - Барт Р. Основы семиологии // Структурализм: «за» и «против». М., 1975, c. 11.

3. Барт 89 - Барт Р. Миф сегодня // Избр. работы. Семиотика. Поэтика. М., 1989, с. 78.

4. Верещагин, Костомаров - Верещагин Е. М., Костомаров В. Г. Язык и культура. М., 1983, с. 56-58.

5. Гудков, Красных - Гудков Д. Б., Красных В. В. К проблеме разграничения ассоциаций и коннотаций // Текст и комментарий. М., 2001.

6. Кобозева 95 - Кобозева И. М. Немец, англичанин, француз и русский: выявление стереотипов национальных характеров через анализ коннотаций этнонимов // Вестник МГУ. Сер. 9. Филология. 1995. № 3.

7. Кобозева 2000 - Кобозева И. М. Лингвистическая семантика. М., 2000, с. 92.

8. Красных - Kpacных B. B. Этнопсихолингвистика и лингвокультурология. М., 2002, c. 232 .

9. Леви-Стросс - Леви-Стросс К. Структура и форма // Семиотика. М., 1983, с. 428.

10. Лосев - Лосев А. Ф. Проблема символа и реалистическое искусство. М., 1976, с. $133-$ 134.

11. Лотман - Лотман Ю. М. Внутри мыслящих миров. М., 1996, с. 148.

12. Лукашевич - Лукашевич E. B. Когнитивная семантика: эволюционнопрогностический аспект. М.-Барнаул, 2002, с. 56-57.

13. Мелерович, Мокиенко-Мелерович А. М., Мокиенко В. М. Фразеологизмы в русской речи. М. 2001, с. 348.

14. Ожегов - Ожегов С. И. Словарь русского языка. М. 1978, с. 282.

15. Пестова - Пестова О.Г. Слова с символическим значением как объект учебной лексикографии // Актуальные проблемы учебной лексикографии. М., 1980, с. 92.

16. Прохоров - Прохоров Ю. Е. Национальные социокультурные стереотипы речевого общения и их роль в обучении русскому языку иностранцев. М. 1996.

17. Скляревская - Скляревская Г. Н. Прагматика и лексикография // Язык - система. Язык - текст. Язык - способность. М., 1995, с. 64.

18. Телия - Телия В. Н. Русская фразеология. М. 1996, с. 235.

19. Тодоров - Тодоров Ц. Теории символа. М., 1999.

20. Толстой - Толстой Н. И. Язык и народная культура. Очерки по славянской мифологии и этнолингвистике. М. 1995, с. 23.

21. Языкознание - Языкознание. Большой энциклопедический словарь. М., 1998, с. 236. 


\title{
Символика животных в переводных произведениях. «Священные» животные (на материале переводов с корейского и китайского языков)
}

\author{
(C) кандидат филологических наук Е. Н. Филимонова, 2004
}

Испокон веков животные служили человеку «символическими выражениями как различных явлений внешней природы, так и собственной его духовной жизни, его страстей, пороков и добродетелей» (Шеппинг 1868,1$)$. Человек обозначал именами и переносил на самого себя качества животных. Для корейца, например, сильный и отважный человек ассоциируется $c$ тигром, одаренный, решительный и храбрый $-c$ драконом, благородный и порядочный - с фениксом, честный и кроткий - c единорогом-иилинем и т. д. Названия животных встречаются и в окружающей нас действительности: в названиях созвездий, растений и т. д. В Корее, например, существуют названия созвездий: кын гом джари - созвездие Большой медведииыь, чагын гом джари - созвездие Малой медведицы, квамаги джари - созвездие Вороны, бэм джари - созвездие Змеи, ёнсу джари - созвездие Барана и др. (ср. русск. созвездия Большой медведищы, Малой медведиць и др.); растений: токки пуль (заячья трава), бэм пуль (змеиная трава), двэджи пуль (трава свиньи) и др. (ср. русск. львиный зев, мышиный горошек и др.).

На Дальнем Востоке широко распространены представления о животных как о первопредках, тотемах. Животным, которое признавалось предком рода, был у корейцев медведь. В числе тотемов также были петух, сорока, лягушка, дракон и собака. В средние века были мифологизированы жаба, сороконожка, червь, змея, а также свинья наряду с персонажами, заимствованными из Китая: единорогом-иилинем, фениксом и другими (см. об этом Ким 2001; Никитина 2001; Самозванцев 2000, 249; 298).

В эпоху Мин животные служили знаками различия у военных чинов. Например, для первого и второго рангов использовали изображение льва, для третьего - изображение тигра и т. д. У гражданских чинов на одежде вышивались не звери, а птицы: журавль, дикий гусь, изапля, мандаринская утка, иволга и др. Квадраты с изображением животных носили на халате (см. об этом Поджио 1892, 237; Сидихменов 2000, 297 298; «Цветы сливы...» Т. 1 1998, 376).

В дальневосточных странах было распространено представление о солнечном зодиаке, в соответствии с которым звездное небо разделено на двенадцать частей, названных именами реальных и мифических животных: мыши, бык, тигр, заяи, змея, лошадь, овцฺа, обезьяна, курица, собака, 
свинья, дракон. В зависимости от положения этих двенадцати созвездий определялось положение солнца в каждый месяц. Соответственно именовались и небесные пространства: западную часть звездного неба называли областью белого тигра, северную - областью черной черепахи, восточную - областью лазоревого дракона, южную - областью красной птицы. По лунно-солнечному, так называемому китайскому календарю, года, месяцы, дни и даже часы приурочивались к одному из двенадцати представителей животного мира, перечисленных выше (см. об этом подробнее Костенко, Петушков 1999, 18-31; Сидихменов 2000, 16).

В Китае с давних пор существовали различные системы классификации живых организмов. Наиболее распространено было представление о «пяти видах существ», различавшихся по их внешнему покрову: панцирные, чешуйчатые, пернатые, покрытые шерстью и гладкокожие. Древние верили, что на земле имеется по 360 разновидностей каждого класса существ и каждый из них имеет свою «главу»: глава панцирных - черепаха, глава зверей, покрытых шерстью - единорог, пернатых феникс, чешуйчатых - дракон, гладкокожих - мудрейший из людей. В Китае и Корее с древности особо почитались следующие животные: дракон, феникс, ичилинь-единорог, тигр и черепаха. Дракона, феникса, uилиня-единорога называли «тремя благодатными мифическими животными» (см. Малявин 2000, 337; 340).Среди реальных животных, которых китайцы и корейцы наделяли магическими свойствами, на первом месте стоит тигр - царь зверей, обитающих на суше. Среди птиц особое место занимают сорока и журавль.

Различные природные явления связывались с действием духов или каких-либо таинственных сил. По древним дальневосточным представлениям, порывистый ветер создавали незримые крылья мифической nтииы феникса; ураганы и смерчи - это полет или борьба драконов; гроза - схватка белого и черного драконов, которые, нанося друг другу удары, проливают на землю обильный дождь и т. п. Также полагали, что зеленыци дракон - символ весны и Востока, хозяин водной стихии насылает тучи и дождь, феникс - лета и Юга, тигр - осени и Запада, повелевает ветрами, черепаха - зимы и Севера (см. Сидихменов 2000, 16; 36; «Цветы сливы...» Т. 1 1998, 360).

В данной статье мы остановимся лишь на тех представителях животного мира, которые в Корее и Китае относят к «священным». Это дракон, феникс, цилинь-единорог, тигр, черепаха, журавль и сорока.

\section{Дракон}

Признанный царь дальневосточного бестиария - это дракон, самый известный символ могущества и власти. Драконы (их было несколько, отличались по виду и функциям) в основном являлись божествами- 
подателями дождя. Дракон до сих пор считается символом сверхъестественных сил, не ограниченных моральными принципами (Сон Хён 1994, 93; Тресиддер 2001, 86; Jober 1962, 468). Однако мифологическая нагрузка, которую несет дракон в русских народных сказках и былинах заметно отличается от дальневосточной традиции: дракон - отрицательный персонаж, многоголовое чудовище в виде крылатого огнедышащего змея, с которым сражается положительный герой (ср. Змей Горыныч). В Корее и Китае считали, что дракон зимует в водоемах, а весной взлетает в облака. В дальневосточной традиции дракон воплощает в себе единство мира в его переменах и творческую силу метаморфоз (см. Малявин 1995, 135).

Изображение дракона в Китае и Корее можно увидеть повсюду, в храмах, во дворцах, на мемориальных обелисках, на древних сооружениях, а в прошлом и на стенах крестьянских домов (в виде картинки или вырезки из бумаги) (см. Сидихменов 2000, 37).

Облик дракона был величественным, суровым и воинственным. Его изображали в самых причудливых формах: он имеет, по преданию, тело змеи, брюхо лягушки, рога оленя, глаза зайца, уши коровы, золотую чешую карпа, волосатый хвост и лапы тигра с четырьмя или пятью орлиными когтями. У дракона есть усы и борода, в которой скрыта «волшебная жемчужина» - символ солнечного сияния. Согласно некоторым поверьям, 117 драконьих чешуек обладают благой силой, а 36 способны причинить вред. Дракон любит драгоценные камни и не любит железо. Свойство дракона, согласно традиционной формуле, - «то сжиматься, то вытягиваться, то скрываться, то появляться и не иметь постоянного обличья» (Малявин 2000, 339; 1995, 135).

Дракон - символ императорской власти:

«Возвращался Дракон-государь» («Классическая поэзия...» 1980, 309).

Проводилась анология между драконом, поднимающимся с земли до небес, и государем, сыном Неба, стоящим выше всех людей.Люди верили во всемогущество дракона, и этим суеверием пользовались правители Китая и Кореи. Стремясь вселить в подданных трепет и суеверный страх, они стали приписывать себе качества этого мифического чудовища. Об императоре говорили так: его лицо - лицо дракона, его глаза - глаза дракона, его руки - руки дракона, его халат - халат дракона, его дети - потомство дракона, дворец императора - дворец дракона, его трон - сиденье дракона. На протяжении веков эмблемой императорской власти служило изображение двух драконов - возносящегося и низвергающегося, которые борются за «огненную жемчужину» (Сидихменов 2000, 246).

Драконий лик - одно из метафорических наименований государя, употребляемое только по отношению к царственной особе: 
«Государыня на мгновенье взглянула на его драконий лик и увидела, что обликом халлим отличается от <всех, кого она> видела раньше» («Повесть о Чёк Сёные» 1996, 102); «Драконий лик императрицы был суров...» (Семанов 2000, 122); «У него вид могущественный, лищо дракона, грозные брови, большой нос. Разве не обладал он внешностью правителя государства?» («Ссянъчхон кыйбонъ» 1962, 44); «Он смотрел вдаль, его небесный лик был прекрасен, длинная драконовая борода великолепна и весь облик - необыкновенно мужественен» (Сон Хён 1994, 49).

Еще одно метафорическое название императора (вана) - «дитя дракона и феникса»:

«Ван, словно дитя дракона и феникса - на нем печать солнца» («Ссянъчхон кыйбонъ» 1962, 44).

Сыновей высокопоставленных сановников отождествляли с драконами и тиграми:

«Шестеро сыновей...министра наружностью и характером удались в родителей; сыновья напоминали драконов и тигров...» (Ким Ман Чжун 1962, 345).

Дракон и тигр символизировали неординарность, избранность. Даже дыхание избранного судьбой человека отождествлялось с дыханием таких священных животных, как дракон и тигр:

«Я увидел, что дыхание, исходящее из левой ноздри вашего, господин, носа подобно дыханию дракона, а из правой ноздри - подобно дыханию тигра. Дыхание дракона соединилось с дыханием тигра быть вам этой осенью князем!» («Нефритовая роса» 2000, 17).

В дальневосточном стереотипном мышлении дракон символизировал лучшие человеческие добродетели: одаренность, решительность, храбрость, мужественность:

«...обручилась с женихом, храбрым и талантливым, подобным дракону»; «У вас норов летящего дракона...» (Ким Ман Чжун 1962, 113; 134);«Благородством осанки и мужественным обликом он напоминал морского Дракона, повелителя ветров и дождей» («Сон...» 1982, 42).

Внешность и быстрота реакции воина также соотносились с драконом:

«Быстротой и обликом напоминал богатырь дракона, рассекающего волны бурного моря...» («Сон...» 1982, 294).

Драконовым и тигровым войском в древности называли королевские войска:

«Подданные короля были опорою страны, а храбрые воины - «драконово и тигрово войско» - ее верной защитой» («Верная Чхун Хян» 1960, 33).

Достижение величия, а также славы в дальневосточной ментальности связывалось с драконом: 
«Недостойный сын мой хоть и молод годами и легкомысленен, однако в ученье преуспел. К тому же и собой хорош. Надеюсь, придет день и он, как дракон, победоносно подымет голову» («История цветов» 1991, 264).

Поклонение дракону выражалось в дальневосточных странах и в том, что в честь дракона строили храмы:

«Государь внял его совету и велел построить невдалеке храм, посвященный дракону» («Корейские предания и легенды...» 1980, 105).

На одежде, утвари, мебели - всюду можно было увидеть изображение дракона. Дракона рисовали на потолках, стенах, ширмах, предметах прикладного искусства и т. д. Зачастую изображались симметричные пары драконов, из которой дракон на левой, восточной стороне композиции возносился вверх, а его визави на западе низвергался вниз.Этот рисунок наглядно представлял природный цикл жизни и его аналог в политике - смену мудрых правителей (см. Малявин 1995, 135).

«...человек...сбросил с плеч узорчатый халат с горами, драконами и водяными растениями и переоделся в некрашеное тонкое платье» («Книга прозрений» 1997, 387); «По стенам было расставлено множество вещей: шкафчики, расписанные фениксами и драконами, комод с ящичками» («Верная Чхун Хян» 1990, 40); «...полочки для гребней с изображением пары драконов» («Братья Хынбу и Нольбу» 1990, 143).

Дракон может указывать на форму: в виде дракона изготавливались различные бытовые предметы:

«Он разгладил бумагу, обдумал сочинение, а потом растер тушь в тушечнице, сделанной в виде дракона...» («Верная Чхун Хян» 1990, 91); «...метелки из перьев фазана с ручкой в форме драконовой головыl...» («Братья Хынбу и Нольбу» 1990, 143); «Ночью, в третью стражу, при свете свечи, которая была сделана в виде пары драконов, маршал спокойно сидел, опираясь на подушку» («Записки...» 1985, 214).

Военным кораблям придавали форму дракона:

«Причудливо изогнутые и разрисованные носы изображали морду и открытую пасть дракона или демона, готовых пожрать врага, почему судна назывались «лодки-драконы» (Паукер 1904, 92).

Наряду с фениксом дракон выступает как «гастрономический» образ. Печень дракона, как и мозг феникса, входили в число восьми изысканных яств, которые подавались к столу корейского вана (см. об этом «Сон...» 1982, 312, 736; «Верная Чхун Хян» 1975, 818):

«...на столиках появляются кушанья из мяса дракона и феникса...» («Сон...» 1982, 28); «Блюда приготовили самые изысканные: ласточкины гнезда, акульи плавники. Чего только здесь не было! Разве что драконовой печенки и мозгов феникса» («Цветы сливы...» Т. 2 1998, 128). 
Дракон в корейской и китайской литературе - цветовой образ: за ним закреплены желтый, зеленый, красный, белый, синий и черный цвета:

«Жена с маленькой дочерью вошли в колодец, оборотились желтыми драконами, затем поднялись на пятицветном облаке и исчезли» («Корейские предание и легенды» 1980, 69); «Причудливо извиваясь, словно длинное туловище синего дракона, письмена на бумагах гласили...» («Сказание о госпоже Пак» 1960, 505); «Гиль Дон между тем сотворил заклинание, и тотчас разом явились пять духов. С востока - зеленый дракон, с юга - красный, с запада - бельй, с севера - черныйџ (Хо Гюн 1960, 174).

Дракон выступает как знак зодиака:

«Тонман вступила на престол на шестом году правления под девизом Чжэн-гуань-Чистого созерцания, в год «дракона», и правила шестнадцать лет» («Корейские предания и легенды...» 1980, 144); «А в день дракона, в час куры, понесут тебя в паланкине» («Корейские повести» 1954, 154).

Драконы часто встречаются в корейских и китайских названиях, например, орнамента на шелковых тканях: «драконы, резвящиеся среди иветов», «драконы и фениксы», «дремлющий дракон»; блюда: «борьба дракона с тигром», которое готовилось из ядовитых змей трех видов, дикой кошки и множества пряностей; сложных женских причесок «рракон, резвящийся в облаках», «дракон, играющий жемчужиной», «дракон, встающий из моря»; крыши китайского дома, крытой зеленой черепицей, - «чешуя дракона» и т. д. (см. Малявин 2000, 494; 529; 545; 576; 1997, 318; 1995, 213; «Повесть о Хынбу» 1960, 442).

Предметом восхищения и почитания была даже слюна дракона. Ее именем назывались ароматические вещества, использовавшиеся в домашних курительницах, а также тушь, которую использовали для написания иероглифов.

«Драконовой слюной» в Китае называли серую амбру, получаемую из Аравии и считавшуюся самым лучшим благовонием («Цветы сливы...» Т. 2 1998, 408).

«Девочка-служанка подлила в курительницу благоуханное масло под названием «слюна дракона» и зажгла фитиль...» (Би Сяошэн 1992, 126).

Тушь «слюна дракона» получила свое название благодаря существовавшей в Китае легенде: во дворце правителя Ся поселились два дракона. Чтобы избавиться от них, он попросил у них слюну. Они тотчас же исчезли, оставив слюну, которая растеклась по дворцу; отсюда и пошло название туши (см. «Роза и Алый Лотос» 1974, 408-409).

«Юноша обрадовался, разгладил бумагу, растер тушь «слюна дракона», обмакнул в нее кисточку из шерсти ласки и одним махом написал...» («Роза и Алый Лотос» 1974, 408-409). 
Дракон отмечен в образном сравнении: с драконом соотнесена красавица:

«Такая женщина...как сладкое пение лютни, способное растрогать даже бездушное железо; как полет дракона, пронзающего облака» (Малявин 1997, 350).

Драконы встречаются и в других сравнительных конструкциях:

«Эта гора похожа на свернувшегося в клубок Дракона или на крыло Феникса» («Сон...» 1982, 31); «...изогнутые сосны на утесах клонятся под порывами ветра, будто старый дракон выгибает спину»(«Верная Чхун Хян» 1990, 32); «Птицы на деревьях там славят добрые дела, а в изогнутых соснах на скалах дует свежий ветерок, будто спит старый дракон» («Верная Чхун Хян» 1960, 47).

Искусство написания иероглифов сопоставляется $c$ драконом, змеей и гусями:

«Когда Ян писал, один иероглиф соединялся с другим, и казалось, будто змея или дракон переползает со строки на строку» («Сон...» 1982, 707); «Он ...написал сочинение, как говорится, одним взмахом кисти и подал его первым. Экзаменаторы взглянули - и каждый иероглиф отметили красной точкой, а каждый стих кружочком. Прямо, как говорится, дракон взлетел в небеса, гуси уселись на ровный песок!» («Верная Чхун Хян» 1990, 91).

С драконами связано множество легенд, поверий, волшебных историй и суеверий. Упоминания о некоторых можно встретить в художественной литературе.

По легенде, в древнекитайском царстве Чжэн (в провинции Хэнань) произошло большое наводнение, так как в мутной реке Вэй схватились в битве драконы.Народ просил принести им жертву, чтобы их успокоить, но министр чжэнского правителя Чжэн-гуна отверг их просьбу, сказав: «Когда мы сражаемся, драконы не обращают на нас внимания, так зачем же нам обращать внимание на драконов» («Корейские предания и легенды...» 1980, 252-253):

«Гао-цзун достиг процветания благодаря фазаньему крику, а Чжэнгун возвысился несмотря на битву драконов»(«Корейские предания и легенды» 1980, 82).

Согласно другому корейскому преданию, в Алмазных горах в озере Девяти драконов, живет ияарь драконов, у которого есть волшебная жемчужина, добытая им в брюхе огромной рыбы и исполняющая все желания своего владельца (см. «Классическая проза Дальнего Востока» 1975, 816). Это тоже нашло отражение в литературе:

«Юноша, сидящий перед Чхун Хян, был очень хорош собою...выхватил большой меч и исполнил танец - ну точь-в-точь, старый дракон из озера Девяти драконов, который, пробудившись от сна, игра- 
ет с драгоценной жемчужиной, исполняющей любые желания» («Классическая проза Дальнего Востока» 1975,336); «Если в столице Цин заслужит любовь Сына Неба и поддержку сослуживцев, то он, как говорится, получит драконову жемчужину, уподобится тигру, оседлавшему ветер, и с ним будет не сладить» («Записки...» 1985, 155).

Существовала древняя легенда о Ён-гуне, который очень любил драконов и даже нарисовал у себя в доме большое изображение дракона, а когда к нему прилетел дракон, очень испугался:

«И пусть она так любит изображение «дракона на картине», что дракон спустится к ней» (Малявин 1997, 350).

C драконом связаны разного рода поверья.Так, например, встреча $c$ зеленым драконом сулила счастье, так как этот дракон - символ весеннего возрождения в природе, недаром он зеленый - цвета молодой травы(см. об этом «Цветы сливы...» Т. 1 1998, 374); «Если увидишь летящего дракона, тебя ждет встреча с великим мужем» (Ким Си Сып 1972, 104).

«Случается, что во время плавания вдруг вдали появляются нагромождение гор, покрытые высохшими деревьями. Если, по мнению капитана, раньше тут никаких гор не было, то это - дракон. Нужно отрезать <прядь> волос и сжечь вместе с рыбьей чешуей и костями. Тогда горы начинают медленно исчезать под водой. Но опасность очень велика, и немногим повезло от нее уберечься» («Нефритовая роса» 2000, 75).

В старину считалось, что увидеть во сне дракона предвещало радостное событие. Это нашло отражение в художественной литературе:

«Прошлой ночью привиделось мне, будто зеленый дракон вдруг появился в озере... Наверно, будет какая-нибудь радость, подумала я» («Верная Чхун Хян 1990, 30); «В испуге очнулся Хон Мо... Он с радостью подумал: «Увидел во сне дракона, значит, жди дорогого сына! - и поспешил к супруге на женскую половину» («Роза и Алый Лотос» 1974, 7).

В старой Корее после переезда в новый дом, перемены квартиры, свадьбы - обычно в виде приветствия спрашивали: «Видели ли вы во сне дракона? - на что следовало ответить: «Видели».Эти выражения сделались просто приветствиями - вне зависимости от того, видели ли тут дракона или нет (см. об этом Конрад 1996, 83).

C драконом образован ряд речений фразеологического характера (далее РФХ). РФХ улететь на драконе означает 'умереть'. Обычно так оповещали о кончине императора:

«Мы с ним расстались на горе Цзиньхуа, он скончался, как говорится, улетел на драконе» («Верная Чхун Хян» 1990, 87); «Когда государь улетел на драконе, злая Люй-Хоу повелела отрубить мне руки» («Верная Чхун Хян» 1960, 104).

РФХ оседлать дракона или взлетел дракон имеют значение 'кому-л очень повезло’: 
«Проводив жениха, наместник вошел на женскую половину и весь сияя от радости, сообщил дочери: - Ну, Гён Пхэ, сегодня ты оседлала дракона! Какая удача!» (Ким Ман Чжун 1962, 113); «В год гэн-чэнь, как говорится, взлетел дракон, и Дань наконец был назначен командиром укрепленного лагеря...» («Нефритовая роса» 2000, 59).

РФХ достичь врат дракона означает 'успешно сдать государственные экзамены и получить высокий чин':

«Принадлежал он <Ли> к знатнейшему роду, в веках прославленному своими выдающимися деятелями, и сам уже с ранних лет достиг Врат дракона» («Сказание о госпоже Пак» 1960, 491).

В основе этого речения лежит народное преданье. Морские и речные рыбы собираются у Драконовых ворот на реке Хуанхэ, где находятся самые высокие пороги, и пытаются перепрыгнуть через пороги; те, которым это удается, превращаются в драконов, а неудачники разбиваются (см. об этом Сказание о госпоже Пак» 1960, 637; «Повести страны зеленых гор» 1966, 328; «Korea»1999, 105-106).

Дракон отмечен в пословицах:

«Правильно говорят: дракон рождает дракона, а феникс феникса» («Корейские повести» 1954, 86); «Туча повинуется дракону, а ветер тигру» («Верная Чхун Хян» 1990, 297).

\section{Феникс}

Самой красивой и самой почитаемой среди пернатого племени была причудливая мифическая птица феникс. Эта мифическая птица сочетает в своем облике черты разных животных: у нее горло ласточки, клюв петуха, шея змеи, хвост рыбы, лоб журавля, головка утки, расцветка дракона, спина черепахи. Перья у феникса перья у него великолепны и замечально красиво завиты, пяти цветов - желтые, белые, красные, синие, черные. Они символизируют пять добродетелей: человеколюбие, долг, пристойность, знание обрядов, верность (см. Сидихменов 2000, 45; Поджио 1892, 275).

Волшебная птица феникс добра и милосердна: она не клюет насекомых, пищей для нее служат семена бамбука, а жажду она утоляет только из чистого родника. Происхождение птицы феникс связывают с солнцем и огнем, поэтому она символизирует тепло, неотделимое от лета и хорошего урожая. В китайской космологии ей присвоено имя «красной» птицы, олицетворяющей юг («Korea» 1999, 349-350; Малявин 2000, 340; Jober 1962,1265).

Присутствие феникса считалось символом мира, признаком процветания страны и благоденствия народа, хорошего правления, ибо в золотой век древности «фениксы кормились близ городских стен» (Ду Фу 2000, 495). 
Согласно легенде, фениксы обитали на горах Даньшань, которые находятся в Центральном Китае. По преданию, на фениксах и луанях летали небожители (см. об этом «Сон...» 1982, 737):

«...спутниц богини Запада несли на себе луани и фениксы» («Сон...» 1982, 373).

Однако в художественной литературе встречается информация о том, что в древности феникса не почитали как священную птицу, не видели в нем ничего примечательного, а только заурядное создание: «...недаром иероглиф «феникс» состоит из знаков «Заурядный» и «Птица» (см. об этом Лим Чже 1964, 160).

Сведения о жизни, местах постоянного обитания и повадках феник$c a$ и т. п. содержатся в художественной литературе:

«Говорят, фениксы не едят ничего, кроме плодов бамбука, - ответила Хун, - а гнезда вьют только на павлонии» («Сон...» 1982, 72); «Ветви павлонии...прячут гнездо//фениксов-птиц, прилетевших в наш край» (Ду Фу 2000, 487); «Феникс, не клюющий проса...» («Приключения зайца» 1990, 356); «Феникс во время дальнего полета не клюет чумизы» («Верная Чхун Хян» 1960, 136).

Повадки феникса были предметом подражания для людей:

«Хун подражала фениксу, лакомящемуся побегами бамбука: делала шаг вперед, потом назад» («Сон...» 1982, 451).

Волшебная птица феникс - эмблема императрицы (Малявин 2000, 340). Император или сверхчеловек отождествлялся не только с драконом, иилинем, но и с фениксом:

«Сам государь воплощает силу и мужество: крупный нос, высокое чело, лик дракона, осанка феникса!» («Сон...» 1982, 468); «Обликом он незауряден, как дитя изилиня и феникса» («Записки...» 1985, 153).

Сыном феникса называли наследника престола:

«Ныне коль феникса сын вас призовет в свой чертог, // Повсюду великое умиротворение воцарится вмиг» («Нефритовая роса» 2000, 107).

Феникс и его самка - самые любимые в Корее и Китае символы супружеского счастья, верности и преданности, а также «символ неразрывной дружбы» (Паукер 1904, 42).Это нашло отражение в корейской и китайской художественной литературе:

«Надо было выбрать тебе такую пару, чтобы, как у фениксов, талантом, положением, характером - всем были бы вы с ним равны»; «И пусть их брак будет счастливым, как у священных птиц-фениксов» («Верная Чхун Хян» 1990, 59; 304).

С лексемой феникс образованы метафорические выражения. Так, «покоями феникса» называли женские покои (см. об этом «Повести страны зеленых гор» 1966, 335).

Одинокий феникс - метафорическое обозначение холостого мужчины: 
«Вмиг с подругой соединит одинокого феникса, холостого - с девицей, при первой встрече» («Цветы сливы...» Т. 1 1998, 48).

Женские головные украшения, брачные шапки в Китае, изображали летящего феникса. Сначала так было принято для цариц и дворцовых дам, а потом мода распространилась и на весь женский Китай. «Фениксова прическа» не только формой своей, но и шпильками, заколками и т. д. напоминала голову феникса (см. Пу Сун-лин 1999, 350).

«Так ладно, - сказала она и при этом подтянула ей «фениксову прическу», которая стала теперь блестеть так, что могла, как зеркало отражать фигуры» (Пу Сун-лин 1999, 135).

Форма головы, хвоста, клюва феникса считались эталонными. В форме головы, хвоста и клюва феникса изготавливались различные предметы быта и одежды:

«Она вынула из волос золотую шпильку с головой птицы Феникс и протянула посыльному» («Сон...» 1982, 48); «В руках она держала веер в виде хвоста птицы феникса» (Ким Ман Чжун 1962, 122); «...из-под юбки виднелись узорчатые гетры и остроносые, похожие на клюв феникса, пурпурные туфельки» («Цветы сливы...» Т. 2 1998, 204).

Феникс - цветовой образ:

«...казалось, разноцветные фениксы, самец и самка, перекликаются в горах Даньшань» («Сон...» 1982, 587); «На высоких-высоких вершинах парами гуляли... пурпурные фениксы») («Повесть о Чёк Сёные» 1996, 25); «А как чудесно ступать по синеве небосвода и впрягать в колесницу белого феникса...» («Классическая проза Дальнего Востока» 1975, 284).

Феникс- звуковой образ:

«А какова мелодия? Представляется, словно Фениксы, самец и самка, поют на рассвете песню любви, и чистые их голоса летят выше облаков, и тот, кто слышит эту песню, пробуждается от сна, и другие птицы кажутся ему безголосыми» («Сон...» 1982, 387); «...звон их яшмовых украшений напоминал песни фениксов и луаней» («Записки...» 1985, 150).

Пару танцующих фениксов можно было увидеть на парадном одеянии минских государей, на карнизах императорских дворцов и даосских храмов, ибо эти волшебные птицы, по преданию, слетались туда, где осуществлялся всеобщий Ритуал бытия (см. об этом Малявин 1995, 135 137).

Наряду с драконами фениксы также украшали ковры, драпировки и стяги:

«Теплая лежанка застелена коврами, сплошь затканными драконами и фениксами» («История цветов» 1991, 483).; «...в углу ширма с шелковыми драпировками, а на них изображены шитьем фениксы» («Сон...» 
1982, 587); « Всюду на пути королевы реяли стяги с драконами и фениксами...» («Записки...» 1985,65).

Даже священная птица феникс в художественной литературе выступает как «гастронимический» образ:

«Во дворце богини их угощали необычными блюдами, изготовленными из медвежьей лапы, обезьяньей печенки, костного мозга nтищьы феникс» (Сидихменов 2000, 163); «Служанка принесла редчайшие яства: осетрину, с душистым сельдереем, вяленое мясо феникса...» («Цветы сливы...» Т. 2 1998, 149).

Феникс входит в состав имен:

«Обрадованный халлим назвал его Пон А - «Птенец Феникса» («Скитания госпожи Са по югу» 1960, 352); «То «Порхающий Феникс»Пибон» («Корейские повести» 1954, 118).

Феникс отмечен в разного рода названиях, в том числе и географических:

«А разве не могла девушка разучить песню Сыма Сян-жу «Феникс ищет свою подругу»? - спросила она»; «Сын Неба, восседая спокойно во дворце «Явление феникса», велел евнуху позвать Ян Со Ю» (Ким Ман Чжун 1961, 107;170); «...водопады Мубон и Пибон (Таниующиий $u$ Летающий фениксы) в ущелье Онню были похожи на потоки изящного шелка» («Предания гор Кымгынсан» 1990, 34).

С давних пор феникс - излюбленный восточный символ женской и мужской красоты и совершенства. С фениксом отождествляются совершенные мужчина и женщина:

«Он здесь, словно феникс с горы Даньшань среди кур! - подумала Хун. - Многих я видела в зеленом тереме, но такого красавца не довелось мне встречать» («Сон...» 1982, 42); «Если спереди на него взглянуть - будто солнце красное по небу катится, а сзади посмотреть словно дракон или феникс» («Сказание о госпоже Пак» 1960, 525); «Она была создана небом, среди женщин - совершенство, как феникс среди птиц или пион среди цветов!» («Роза и Алый Лотос» 1974, 249); «...подобно порхающему фениксу, она затмила красавиц всех предыдущих поколений» (Ким Ман Чжун 1961, 84).

Глаза красавца уподабливаются глазам птицьь-феникса:

«Увидев, что юноша с яшмовым лицом и фениксовыми глазами равнодушен к красоте гор и рек, он удивился...» («Ссянъчхон кыйбон» $1962,28)$; «...его яшмовое лицо и глаза феникса, приподнятые к вискам, чуть-чуть захмелели от пожалованной королем чарки вина» («Скитания госпожи Са по югу» 1960, 511).

Руки красавца - крылья феникса:

«...руки его, словно крылья феникса...» («Ссянъчхон кыйбон» 1962, 26). 
В фениксе все совершенно, даже его жир. С жиром феникса соотнесены женские груди:

«Благоуханные от пота и пудры, // колышутся над цитрой небрежно. // Теплые, белые и, как феникса жир, нежные» (Би Сяошэн 1992, 11).

Полагали, что у феникса чудный голос. Чистые, красивые мужские и женские голоса уподабливаются пению феникса:

«Фениксовый голос его звенел, как яшма» («Ссянъчхон кыйбон» $1962,28)$; «Ее голос был так нежен, что Сяньфэну показалось, будто с ним разговаривает феникс, а не женщина» (Семанов 2000, 48); «Голос был печален и нежен - ... словно одинокий Феникс с Даньшаньских гор призывал подругу» («Сон...» 1982, 59).

Феникса принято было изображать на всех музыкальных инструментах. Звучание музыкальных инструментов также сравнивается с пением фениксов:

«Флейты пели, словно фениксы» («Корейские повести» 1954, 171).

Феникс отмечен в крылатом выражении:

«На перьях феникса спорят тысячи красок весной. Весной не найдешь одинаковых в мире вещей. Эти фразы сочинил Мунме» (Сон Хён 1994, 48).

Наряду с драконом феникс отмечен в составе пословиц:

«Существовали жесткие правила занятия должностей, деление на высших и низших было очень строгим. Требовалось, как говорилось, чтобы рыба сначала превратилась в дракона, курица стала фениксом» (Сон Хён 1994, 41); «Где сиро да бедно, там феникс не садится» («Цветы сливы...» Т. 1 1998, 95); «Как говорится, появился феникс, нашлась $и$ подруга, появился герой - нашелся конь-дракон» («Верная Чхун Хян» 1990, 43).

\section{Цилинь (единорог)}

По китайской и корейской мифологии восточный единорог-циилинь (кор. кирин) - животное, которое не ест ничего живого, только засохшую траву, не топчет трав, отличается кротким нравом. Считают, что цилинь показывается людям как предвестник рождения мудреца или появления на престоле совершенномудрого государя. Если этого зверя не видно, то нельзя рассчитывать на появление в мире мудрого человека (см. «Сказание о госпоже Пак» 1960, 673). Цилинь служит эмблемой мира, радости и веселья, а также доброты, прямоты и честности. Полагали, что циилинь живет до тысячи лет (см. об этом Гриффис 1884, 4849;Поджио 1892, 274; Jober 1962,1625).

Внешний вид ичлиня описывается так: «Цилинь - мифическое животное, покрытое чешуей, с телом оленя, ногами лошади и хвостом коровы, бурого цвета, с шишкой или рогом на голове» (Ким Си Сып 
1972,165; «Верная Чхун Хян» 1990, 381; «Корейские предания и легенды...» 1980, 252). Голос единорога напоминал «колокольный звон» (см. Малявин 2000, 340).

Вера в миф о наступлении всеобего счастья и процветании при появлении этого мифического животного нашла отражение в художественной литературе:

«Он разослал во все концы страны гонцов собирать сведения о всеобщем счастье. Местные власти выдумывали во всю: одни говорили, что видели пляшущих фениксов, другие утверждали, что объявился Единорог, третьи клялись, что стала прозрачной Желтая река» («Сон...» 1982, 379).

В художественной литературе встречается информация о жизни, повадках и местах обитания этого мифического животного:

«Живут Единороги не стадами, а поодиночке, в захолустных уголках, избегая шумных поселений» («История Цветов» 1991, 354); «Цилинь, травы не мнущий...» («Приключения зайца» 1990, 356).

Цилинь символизировал прославленное потомство. Необыкновенно умных, незаурядных детей называли «сыновьями цилиня».

«Мальчик оказался смышленым, как отец, и красивым, как мать, истинно дитя Единорога и Феникса!» («Сон...» 1982, 592).

Цилинь входит в состав имен:

«Халлим обрадовался и назвал его Лин Я, что значит «Дитяцилинь» (Ким Си Сып 1972,341).

Изображение цุилиня ставилось на кладбищах знатных людей:

«Взгляни, как птицы // До седой зимы // На кладбище // Гнездятся без тревоги, // Где, сторожа // Могильные холмы, // Гранитные // Лежат единоро-ги» (Ду Фу 2000, 70; 352).

Цилинь выступает как «гастронимический» образ:

«Вяленый единорог лежит на блюдах из белого нефрита...» («Цветы сливы...» Т. 2 1998, 57; Т. 1, 319); «...коралловые кубки с нектаром и лотосовым настоем, чтобы запивать сушеное мясо единорога» («Повесть о Сим Чхон» 1960, 226).

Цилинь - узор на одежде:

«Юэ-нян надела расшитый цилинями пурпурный атласный халат с широкими руковами» («Цветы сливы...» Т. 2 1998, 55).

Много легенд и поверий связано с иилинем.

По одной легенде, пленение излиня произошло в 481 году до н.э. Этим кончается летопись царства Лу, названная «Чуньцю» («Весны и Осени») и приписываемая Конфуцию. Однако царство Лу было захвачено царством Чу только в 256 г. до н.э., поэтому многие связывают появление ичилиня со смертью Конфуция, которая последовала через два года после этого. Конфуций сетовал, явление чудесного зверя было 
напрасным: у него уже не оставалось никакой надежды на воскрешение нравов древности (см. «Корейские предания и легенды...» 1980, 252; Малявин 2000, 341). Упоминания об этой легенде встречаются в художественной литературе:

«Счастье и несчастье переменчивы. Они зависят от самих людей. Поэтому иньский Чжоу погиб из-за Красной птицы, а царство Лу пало, хотя и был пойман единорог-цฺилинь» («Корейские предания и легенды...» 1980, 82).

Другая легенда гласит, что «при императоре Хуэй-цзуне, в годы Дагуань, у одного крестьянина корова отелилась иилинем. Деревенские жители не поняли, <что это циилинь>, сочли его вредным и забили палками. Власти же, узнав об этом происшествии, провели расследование, и оказалось - действительно благовестное существо! Донесли владыке. И тогда во все провинции были разосланы рисунки, изображающие изилиня, чтобы крестьяне знали, как он выглядит. Тому же, у кого появится изилинь, была обещана щедрая награда» («Нефритовая роса» 2000, 93-94).

Согласно еще одной легенде, именно единорог принес на своей спине прародителю цивилизации Фу Си знаки, от которых произошли письмена.

Существовало поверье, что, если снился изилинь, то это к счастливой беременности. На Дальнем Востоке иилинь считался существом, приносящим сыновей (см. «Цветы сливы...» Т. 2 1998, 408). Это нашло отражение в литературе:

«Весной в двадцать пятый год Изя-цзин Хэ Юю приснилось, будто его обнимает яшмовый иилинь. С этого времени супруга Чэн забеременела и через десять месяцев родила мальчика» («Записки...» 1985, 105).

Цилинь часто встречается в образных сравнениях. Так как в корейской и китайской мифологии цилинь отличается кротким нравом, кроткая девушка, а также дети уподабливаются циилиню:

«В преданности родителям не было равных Чхунхян, а кротостью нрава она могла сравниться лишь с ичилинем, и не было в округе человека, который не хвалил бы ее дочернее послушание» («Верная Чхун Хян» 1990, 21); «Росли они <дети>, как яшмовые деревца и были под стать ичилиням» («Сказание о госпоже Пак» 1960, 545).

В дальневосточном стереотипном мышлении цилинь отождествлялся с незаурядностью, изысканностью:

«Людей далекой окраины, в глаза не видавших столичной роскоши, ошеломило великолепие посланника. Он казался им единорогом на земле, фениксом в облаках» (Ким Ман Чжун 1961, 154).

Единорог встречается и в других сравнительных конструкциях: 
«Словно единорог // Спрятал след свой в пещерную тень, // А в полях // наконечники стрел Сушэнь...» («Классическая проза Дальнего Востока» 1975, 289).

Феникс и ичилинь-единорог зафиксированы нами в пословице:

«Феникс и единорог даже для младенияа добрый знак, не уступала Ён Са» (Ким Ман Чжун 1962, 89).

\section{Тигр}

В дальневосточной ментальности, тигр почитался как царь зверей и хозяин леса («Корейские предания и легенды...» 1980, 131).У тигра его царственное достоинство, как верили китайцы и корейцы, в буквальном смысле написаны на лбу, где полоски на шкуре складываются в знак ван - «государь» (см. Малявин 2000, 341). В Корее тигр воспринимали как божество, историческим свидетельством этого являются различные названия тигра: «горное божество», «горный господин», горный государь», «Горный дух», «Горный герой» (см. Конрад 1996, 106).

Тигр символизировал силу, властолюбие, суровость, могущество, отвагу и свирепость (см. Гриффис 1884, 48; Паукер 1904, 42; Сидихменов 2000, 44).

В Китае и Корее тигр имел славу пожирателя демонов, когти тигра носили в качестве оберега. В Древней Корее с обруча королевских корон, сделанных из золота и нефрита, на тонких крученых золотых проволоках, свисали пятьдесят восемь тигриных когтей из нефрита и множество золотых блесток, подобных потоку солнечных лучей. Когда правитель, воплощавший для подданных все формы природной энергии и, в первую очередь, солнечную, поворачивал голову, блестки переливались, а подвески из нефрита - издавали вибрирующий звук, производящий неизгладимое впечатление на окружающих (см. «Корея. Карманная энциклопедия» 2000, 336-337).

Люди, преследуемые демонами, пили отвар из тигровой шкуры. Чтобы тигр наводил ужас на злых духов, голову этого хищника рисовали на стенах жилых домов и монастырей и вышивали на одежде и обуви детей (см. Малявин 2000, 532; Тресиддер 2001, 369). Защитная сила тигра прослеживается и в древней традиции надевать на детей тигровые шапки. В старые времена, когда женщина отправлялась в дальнюю дорогу, то она пришивала к юбке кусок тигриной шкуры. Считалось, что в таком случае дух тигра обеспечит ей безопасность (см. Тресиддер 2001, 369; «Корея. Карманная энциклопедия» 2000, 336-337). Часть этих традиций нашла отражение в художественной литературе:

«Та как раз шила малышу к празднику... амулеты, плела из полыни тигрят, чтобы отвадить злых духов...» («Цветы сливы...» Т. 2 1998, 105). 
Тигр считался заклятым врагом змей и крыс. Китайцы верили, что тигр обладает недюженным умом, и прожив на свете пятьсот лет, становится совсем белым - как седой старик. Вход в монастыри, правительственные здания, богатые магазины, жилые дома феодалов украшали и оберегали каменные изваяния тигра (см. Малявин 2000, 341; Сидихменов 2000, 44).

Тигр символизировал военную доблесть. Особые знаки с изображением тигра, так называемые тигровые знаки вручались в Китае полководцам:

«Он был защитником отчизны... // Тигровый знак носил с собою» («Цветы сливы...» Т. 2 1998, 393; 425).

Воины рисовали голову тигра на щитах; ее гравировали на деревянных дверях военных укреплений для устрашения неприятеля. В древние времена, стремясь вселить страх в стан противника, китайские воины в тигровых шкурах шли на врага с дикими криками, напоминавшими рев настоящего тигра.

По древним дальневосточным представлениям, тигр повелевает ветрами, а дракон насылает тучи и дождь (см. об этом «Цветы сливы...» Т. 1 1998, 360). Это отмечено нами и в художественной литературе:

«Давно известно, что ветер насылает тигр, а тучи - дракон» («Цветы сливы...» Т. 1 1998, 27).

На протяжении многих столетий тигр считается в Корее национальным символом. Тигр - это постоянный герой корейских сказок, мудрый, могучий, сильный, иногда свирепый, а иногда добрый и наивный. Большинство корейских сказок начинается так: «Это было в те далекие времена, когда тигр умел курить, а животные - говорить человеческим голосом» (см. «Сказки народов мира» 1987, 103). Тигр упоминается и в одном из самых важных для Кореи письменном источнике мифе об основателе корейской нации Тангуне (см. «Корейские предания и легенды...» 1980, 37-38).

Много поверий связано с тигром. Считалось, что бельий тигр предвестник беды, так как он связан с Западом, где лежит страна мертвых (см. об этом «Цветы сливы...» Т. 1 1998, 374).

«Дракон ли зеленый тебя повстречает, // бельий ли тигр - никогда // Люди не скажут, тебя ожидает // радость или беда...» («Цветы сливы...» T. 1 1998, 287).

Упоминания о повадках этого животного, его поведении в природе в том или ином виде встречаются в художественной литературе:

«Когда хищный орел собирается закогтить птицу, он перестает взмахивать крыльями и парит низко над землей. Когда свирепый тигр хочет задрать зверя, он прижимает уши и припадает к земле» («Записки...» 1985, 205); «Тогда тигр уперся передними лапами в землю, чтобы 
задними нанести удар, но храбрец успел отбежать в сторону. Надо сказать, что обычно тигр бьет свою жертву задними лапами или хвостом, а если промахивается - наполовину теряет силы» («Цветы сливы...» Т. 1 1998, 28).

В дальневосточной ментальности стереотипный образ тигра многогранен. В Старой Корее тигра воспринимали не только как божество, но и как чудесную силу, которая обладает нравственными понятиями, умеет отличать добро от зла, добродетель от порока, обладает силой и желанием карать за порок и награждать за добродетель. Тигру доступна жалость: от него можно избавиться усиленными просьбами и вообще поклонением. С помощью чудесной силы тигра можно противостоять другим бедствиям: силе других злых духов, болезням и пр. (см. об этом Конрад 1996, 106).

В художественной литературе за тигром, с одной стороны, закреплены многие добродетели:

«Тигр - великолепен! Он талантлив и остроумен, он всесторонен образован и великодушен, он мудр, он почтителен к родителям, он быстр и ловок, он силен и отважен» («История цветов» 1991, 526); «Разве тигры не добрее людей? Тигры не едят травы, плодов и листьев, не едят насекомых и рыбу, не любят дурманящего хмельного зелья, не трогают стельных животных. В горах они охотятся на косуль и оленей, а спускаясь в долины, - на коров и лошадей. Для своего пропитания тигры не зарятся на чужое добро и не таскаются по судам»; «Ведь недаром говорят, что тигры отважны и справедливы. Если даже взять один кусочек полосатой шкуры тигра, то разве нельзя гордиться ее красивейшим в мире узором? Tuгры не пользуются никаким оружием, кроме своих клыков и когтей, но они широко прославились воинским умением. В старину тигры изображались на самой различной посуде: так люди ценили их почтительность к родителям. Тигры никогда не съедают свою добычу одни, всегда делятся ее остатками с воронами, ястребами и муравьями. Не пересказать словами всей душевной доброты тигров, они щадят невинно оклеветанных, не трогают больных и калек, не нападают на тех, кто одет в траур» («Классическая проза Дальнего Востока» 1975, 300; 305).

С другой стороны, тигр среди тех животных, которые считаются опасными и внушают ужас:

«Среди тварей всех и на земле и в небе, // Что страх внушает, что вселяет ужас? // Тигр белолобый, волк или гиена, // Удав, гадюка, скорпион, стоножка...» («Корейская классическая поэзия» 1956, 227); «А там полосатый разноцветный тигр-великан крадется, грозно опустив острую бороду из железных нитей. Вот ужас! Рев его подобен грому, башка с горой сравнится, спина, это полумесяц, а шерсть горит огнем. Мечхвост бьет тигра по бокам. Зверь разевает пасть кроваво-красную, грозя 
зубами - зубьями бороны. Словно летящая молния, всюду сверкает его тело. Он натыкается на все, рыщет по ущельям, на камни налетает с грохотом, и с треском валятся деревья. Он величав и грозен. Настояший владыка гор! Вдруг вспыхивает его отвага, глаза-факелы мечут молнии, он выпускает когти на передних лапах, острые, как зубы пилы. Тигр вздохнет разок поглубже - деревья закачаются, а зарычит погромче горы так заходят ходуном. Небо темнеет, а душа уходит в пятки» («Повесть о зайце» 1960, 302-303).

В корейском языке существует целый ряд образных сравнений, связанных с тигром. Корейцы обращаются к образу тигра при характеристике:

1. сильного духом человека: «Облик его был полон достоинства, а могуществом духа он походил на свирепого тигра в горах!» («Верная Чхун Хян» 1990, 92);

2. ловкого человека: «Оксвэ, как тигр, перепрыгнул на его корабль...» («Предания гор Кымгынсана» 1990, 96);

3. непредсказуемого, хитрого и осторожного человека: «У вас... повадки крадущегося тигра» (Ким Ман Чжун 1962, 84);

4. отважного человека: «Вчера ваш дух был смущен диковинными событиями, сегодня же, хвала небу, вы вновь - тигроподобный богатырь!» («Повесть о Чон У Чхи» 1960, 267);

5. разъяренного, свирепого человека: « «Разъяренный Начжа метался и прыгал, словно тигр» («Сон...» 1982, 175); «Услышав призывы брата о помощи, он подскочил, будто свирепый тигр, выпучил свои злые, налитые кровью глазищи и с бранью обрушился на Хынбу...» («Братья Хынбу и Нольбу» 1990, 120);

6. человека, вызывающего у других людей страх и ужас: «Bce трепетали перед ним, как перед тигром» («Черепаховый суп» 1970, 73).

Тигр в дальневосточной литературе цветовой образ:

«А там полосатый разноцветный тигр-великан крадется...» («Повесть о зайце» 1960, 302); «Все там вокруг волнисто: кончилась гора Сураксан, пошли небольшие холмы; кончились цепи холмов, следом вздымается гора Чоннамсан... белым тигром лежит Манни» («Корейские повести» 1954, 83).

Тигровую шкуру использовали в быту. Корейцы полагали, что разостлать шкуру тигра на свадебном паланкине или вообще как подстилку на пороге, скамейке и т. д. - избежишь несчастья (см. об этом Конрад $1996,105)$.Правители во время торжественных церемоний также восседали на шкуре тигра, которая символизировала их власть и авторитет (см. «Республика Корея. Путеводитель» 2000, 35).

«Наконец появился паланкин Государева советника, открытый без крыши, устланный тигровой шкурой» («Цветы сливы...» Т. 2 1998, 218); 
«Поставил скамеечку, крытую тигровой шкурой и протянул шлею» («Верная Чхун Хян» 1960, 38).

Тигр - знак китайского зодиака:

«В год «тигра», на пятидесятом году царствования китайского правителя Яо, Тангун основал столицу в Пхеньянской крепости (ныне Согён - Западная столица), а страну свою назвал Чосон» («Корейские предания и легенды...» 1980, 38); «Сон Чхун Хян, рожденная в год мыши, в пятую луну - месяц мыши, в двадцатый день тигра и час лошади, живущая в Корее...томится в тюрьме» («Корейские повести» 1954, 154).

В виде тигра сделан корейский национальный инструмент О. В конце представления тигра три раза ударяют по голове и проводят бамбуковой палочкой по зарубкам («Корея. Карманная энциклопедия» 2000, 427-428).

С тигром связано множество поверий, суеверий и примет, которые подробно описаны Н. И. Конрадом (см. Конрад 1996, 104-106). Приведем некоторые из них, которые, как нам кажется, наиболее ярко отражают наивные представления корейского народа об окружающей их природе. Например, увидеть во сне тигра - означает благополучие во всех делах, на том основании, что иероглиф «тигр» и «хорошо» - омонимы; если тигр съест тысячу человек, он обращается в буддийского монаха; тигр имеет способность видеть сквозь бумажную склейку окон и дверей и узнавать, сколько людей в доме и т. п.

Множество легенд связано с царем зверей. Одна из легенд о сверхъестественной силе белого тигра зарегестрирована нами а художественной литературе:

«Только он это выговорил, как с вершины горы налетел ураганный ветер, и на равнину с рыком - словно небо раскололось в грозу - выскочил огромный белый тигр! Белый, как снег, с желтыми глазищами, что горели, ровно факелы, с алой, будто в крови, пастью, он пронесся громадными прыжками над равниной скорее молнии... - Уж не тот ли это тигр, что глотал железные копья хана Елюя? Великая напасть в наших краях этот зверь! Никому не под силу с ним справиться! На северовосток от Хэланьшаня стоит мрачная Тьма-гора, а на ней, по преданию, вот уже четыре тысячи лет обретается этот свирепый тигр. В свое время хан Елюй, уверовав в свою силу, пошел на страшного зверя, да ничего у него не вышло. Трижды ходил хан, трижды метал железные копья - и трижды тигр их заглатывал! А ведь в каждом копье весу было побольше тысячи цзиней! Не сосчитать, сколько охотников и воинов погубил этот зверь! Потому жители северных стран построили на Тьме-горе жертвенник и каждую весну и осень доставляют на алтарь быков и баранов. Если не принести ему жертвы, зверь сходит с горы и поедает 
людей, многие тысячи уже убил! Никто не охотится в тех местах с давних пор, все его страшатся!» («Сон...» 1982, 474).

Тигр зафиксирован в образном сравнении. Величественная осанка мужчины соотнесена с грацией тигра:

«Манеры у него - вельможи из сказки, осанка - тигра» («Корейские повести» 1954, 164).

Тигр отмечен в составе РФХ. РФХ соблюдать осторожность среди тигров имеет значение: 'проявлять необычайную осторожность среди врагов':

«Только прошу, соблюдай осторожность среди тигров, береги себя и с честью выполни приказ императора, - сказал на прощание тесть» (Ким Ман Чжун 1962, 150). сти':

РФХ дергать тигра за бороду означает: 'смотреть в глаза опасно-

«Я не сомневался в силе своей секиры, самолично дважды «дергал тигра за бороду», но остался жив только по вашей милости» («Сон...» 1982, 199).

Tuгры встречаются в иносказательных выражениях и компаративных РФХ:

«Я вижу, человек нападает на тигрицу, которая его не трогала» (Семанов 2000, 141); «Не от тигра ли ты бежала, что так запыхалась? - с добродушной усмешкой спросила Мать Хи Джуна, видя, что гостья не может перевести дух от быстрой хотьбы» (Ли Ги Ен 1967, 230); «Этот юноша не побоялся вместо своей сестры войти в логово тигра» («Записки...» 1985, 184); «Может, и стал Тхэ Бэк Пхун главарем шайки, но мне пока вреда никакого не причинил. К тому же сила у него небольшая. Так не лучше ли оставить его в покое? А то шума наделаем и ничего не добьемся. Ведь это все равно что пощекотать соломинкой спящего тигра» («Феи с Алмазных гор» 1991, 72); «Тут он просто запрыгал от радости: «Вот уж подлинно я-рыба, выскользнувшая из сети, тигр, вырвавшийся из западни. Если бы не мое хитроумие, довелось бы разве мне увидеть родные горы и реки?» («Приключения зайца» 1960, 321).

Тигр отмечен во многих пословицах: «Младенцу ли в пеленках презрительно взирать на взрослых! T⿰ь подобна щенку, еще не видавшему тигра!» («Роза и Алый Лотос» 1974, 54); «Недаром гласит пословица: «Убежал от волка - наскочил на тигра» («Феи с Алмазных гор» 1991, 132); «Знаешь пословицу: «Тигр, вырвавшийся из западни, злее, чем тигр, в западню не попавший. Для нас с тобой этот тигр - Яньский князь» («Сон...» 1982, 364); «Верно говорят: не узнаешь, что у тигра на yме, у человека на душе, - в гневе вскричал Симынь...» («Цветы сливы...» Т. 2 1998, 251); «Недаром говорят: «Убежишь от косули - 
встретишь тигра»; «В старину говорили: «Не войдешь в логово тигра - не поймаешь тигренка» («Приключения зайца» 1990, 343; 346); «Как говорится в пословице: «Нарисовал тигра, кости ему уж не подрисуешь, полюбил человека, душу его уж не разгадаешь» («Скитания госпожи Са по югу» 1960, 341).

\section{Черепаха}

Черепаха в Китае и Корее - древнейший, окруженный особым почтением символ космического порядка, высокодуховное существо (см. Тресиддер 2001, 409; Jober 1962, 1590).

Черепаха считалась священным животным; она олицетворяла долголетие, силу, выносливость, терпение и постоянство (Гриффис 1884, 48-49; Паукер 1904, 42; Тресиддер 2001, 409). Черепаха - животное, покрытое темным панцирем, медлительное в своих движениях, имеет голову змеи и шею дракона, зарывается в зимнее время в землю. Она всегда напоминает о зиме и своим поведением дает знать, когда начинается и когда кончается зимний сезон. Понятие черепаха в дальневосточных странах ассоциировалось с зимой и севером. Она выступала под именем Черного Воина. Ее куполообразную спину уподобляли небесному своду, а брюхо - земле. Долголетие черепахи стало символом вечности; верили, что она живет до трех тысяч лет. Именно на спине волшебной черепахи, выползшей из Желтой Реки, были начертаны знаменитые Восемь триграмм. Изображение сплетенных черепахи и змеи с глубокой древности служило зримым образом сотворения мира (см. об этом Малявин 2000, 341; Сидихменов 2000, 45).

Черепаха - популярный персонаж древних корейских и китайских мифов и легенд, где она предстает символом мироздания. В преданиях черепаха очень усердная, трудолюбивая и исполнительная, единственный посредник между подводным владыкой Драконом и наземным миром.

Черепаха - один из излюбленных образов корейского изобразительного искусства. Черепаха широко представлена в корейском искусстве ваяния: каменные черепахи служат постаментом для памятников на могилах знатных людей или основанием зданий. Черепахи украшают императорские дворцы, цокольную часть зданий, камни в садах и парках, сосуды для воды, каменные бассейны.

Черепаха - составная часть идеальной картины природы, гармонии животного и растительного миров:

«Вижу белку на крутой скале, // Черепаху возле быстрой речки. // В таволге весь день звенят пичуги, // Над пионами жужжит пчела» (Бамбук в снегу» 1978, 281).

Черепаха - цветовой образ: 
«Золотая черепаха // Карабкается по песку» («Классическая поэзия...» 1977, 481).

Черепаха - «гастрономический» образ:

«Братья Ким очень любили черепаховый суn и частенько лакомились им» («Черепаховый суп» 1970, 102); «Черепаховый бульон особенно вкусен!» («Повесть о зайце» 1960, 292).

Паниирь черепахи - материал, который использовался для изготовления домашней утвари:

«Были поданы вареная грудинка на черепаховом блюде и свинина на маленьком блюде» («Роза и Алый Лотос» 1974, 322-323); «Ведь из панциря черепахи сделана большая ширма...» («Верная Чхун Хян» 1990,53); «В левой руке у каждого кувшин, в правой - черепаховая шкатулка» («Братья Хынбу и Нольбу» 1990, 141); «перила из черепаховых панцирей» («Повесть о Сим Чхон» 1960, 225).

Образ черепахи характерен для многих предметов быта:

«Вот кувшин... в виде черепахи, расписной китайский и позолоченный...» («Верная Чхун Хян» 1990, 44); «...сосуд для воды, изображающий черепаху...» («Повесть о Хынбу» 1960, 441)

В древности в Китае и Корее в особо важных случаях гадали по трещинам, появившимся на панцирях черепах. Ей приписывали колдовскую силу (см. об этом Малявин 2000, 305; Самозванцев 2000, 249):

«А сейчас на черепахе гадали. Пришли бы пораньше - и вам погадали бы» («Цветы сливы...» Т. 2 1998, 69).

В XVI веке корейским адмиралом Ли Сун Сином было построено первое в Восточной Азии боевое бронированное судно в форме черепахи - кобуксон (корабль-черепаха), в нескольких блестящих сражениях наголову разбившее превосходящий численностью японский флот, отрезав оккупационные войска от баз в Японии (см. об этом Зайчиков 1951, 12).

«Хун передала Су Юй-цину рисунок, на котором был изображен корабль в виде морской черепахи. С четырех сторон у него «ноги», а внутри - особая машина. Стоит ее запустить, и корабль-черепаха поплывет против течения. Если поднимет «голову», взберется на любую волну. Скорость у него как у ветра. Внутри основного, большого корабля еще один, маленький. Тот, что снаружи, может качаться на волнах, а тот, что внутри, всегда в покое, и как раз во внутреннем корабле прячутся воины и хранится оружие» («Сон...» 1982, 299).

Черепаха встречается в названиях. В Китае в руководстве по игре на цине, созданном в XVI веке, один из музыкальных приемов носит название «священная черепаха выходит из воды» (Малявин 1995, 80).

Черепаха зафиксирована в иносказательном выражении:

«Сейчас мы бедны, и вам до сих пор приходится трудиться. И если я, превратясь в пса, который сторожит дом, в черепаху, которая еле во- 
лочит хвост, не сыщу себе в мире известности, но так и не засверкает моя слава и нечем мне будет порадовать душу родимой» (Ким Ман Чжун 1961, 50).

Черепаха отмечена в образном сравнении. Походка красавицы отождествляется с черепахой. Следует отметить, что такая лексема, как черепаха в русском языке коннотативно обусловлена. В русской языковой ментальности черепаха связывается с медлительностью и неуклюжестью <ср. ползет (тащится) как черепаха>, поэтому для русской женщины сравнение ее походки с черепахой едва ли вызовет положительные эмоции.

«Вслед за слугой ступала она по дороге, залитой солнце, словно большая черепаха по белому песку...» («Роза и Алый Лотос» 1975, 335).

Черепаха встречается и в других сравнительных конструкциях:

«Судьба моей дочери, чистой, как яшма, будет тогда словно поломанный панщирь черепахи...» (Верная Чхун Хян» 1960,58); «...я все вытерплю. Я не черепаха, которую хоть насквозь проколи, капли крови не увидишь» («Цветы сливы...» Т. 1 1998, 43).

Несмотря на тот факт, что черепаха почитается в двух странах как «священное» животное, она может служить бранным словом, а также символом лени:

«Ах ты, черепаха, проклятая!»;«Погналась за этим черепашьим выродком, так и жила бы с ним» («Цветы сливы...» Т. 1 1998, 216; 220); «Ты, оказывается, последний лентяй, подобно черепахе в нашем дворце» («Предания гор Кымгынсан» 1990, 87).

\section{Сорока}

Сорока - счастливый знак в Корее и Китае, означающий радость, счастливый брак (Jober 1962, 1041).Пять сорок служили символом традиционных «пяти видов счастья» (здоровье, богатство, потомство, долголетие, знатность). Считалось, что крик сороки предвещает встречу с друзьями. В русской традиции сорока - птица, связанная, с болтливостью (напр., трещит как сорока; заладила (затвердила) сорока Якова (одно про всякого); всякая сорока от своего языка погибает и др.).

Сорока считается национальной птицей Кореи (см. «Республика Корея. Путеводитель» 2000, 97).

В дальневосточном стереотипном мышлении сорока - птица, передающая самые добрые вести. Это нашло отражение в литературе:

«На юго-востоке птичий крик считается дурным предзнаменованием, а сорочье стрекотание - добрым. Поэтому сороку называют еще «радующая» («Нефритовая роса» 2000, 93); «A couple of magpies over a gingko tree // Fly with vigorous flaps of wings, bringing happy news» (Park Young-man 1999, 35). 
Художники Кореи и Китая обращались к изображению сороки и цветущей сливы, что означало большую радость, а изображение двух сорок служило «эмблемой счастья». Такие «эмблемы» вывешивались на улицах и в домах в праздничные дни (см. Сидихменов 2000, 380; 29).

Сороки - вестницы весны:

“...magpies telling the news of spring..." (Park Young-man 1999, 79).

Сорока выступает и как «гастрономический» образ:

«И зачем это вы влезли на такое высокое дерево? Уж не хотите ли полакомиться птенцами сороки?!» («История цветов» 1991, 126).

С сороками связана одна из самых романтических дальневосточных легенд о двух звездах в созвездии Водолея Кённу (Пастух) и Чиннё (Ткачиха), которые полюбили друг друга и поженились. Однако Небесный владыка разлучил их за то, что, увлекшись любовью, они забыли свои обязанности: пасти скот и ткать шелк. Кённу отправили на западный берег Серебряной реки (Млечного пути), а Чиннё - на восточный. Встречаться они могли лишь один раз в году - в седьмой день седьмой луны по традиционному дальневосточному календарю. Переправиться через Серебряную реку можно лишь по Сорочьему мосту, а сороки, как не спешили, быстро построить его не могли, так как очень долго искали ветки для моста. Известно, что в седьмом месяце года сороки бывают плешивыми. Считается, что это оттого, что они носят на голове ветки для Сорочьего моста (см. «Феи с Алмазных гор» 1991, 15-16; Chevalier, Gheerbrant 1994, 553). И действительно, именно в этот день созвездия Орла и Лиры сближаются в небе на фоне Млечного пути.

Этот день является неофициальным праздником во многих дальневосточных странах. Сорочий мост в корейских повестях - символ встречи влюбленных (см. Троцевич 1975, 190).Ссылки на эту легенду часто встречаются в художественоой литературе:

«Сороки уже навели свой чудесный мост через Серебряную реку»; «Сорочий мост - место любовной встречи, потому третий там всегда лишний» («Сон...» 1982, 27); «И вот как сказал бы здесь человек с тонкой душой: «В сей миг Пастух уже ступил на мост, построенный сороками...» (Би Сяошэн 1992, 136).

Выражение от небесного брода давно улетели сороки в корейской литературе символизирует окончание любовного свидания (см. Ким Си Сып 1972, 152):

«Мы расстаемся, и кто знает, когда свидимся вновь... От Небесного Брода давно улетели сороки...» (Ким Си Сып 1972, 24).

В Китае с давних пор существовало поверье, что если жена во время отсутствия мужа была ему неверна, то половинка зеркала, которую муж оставлял жене, превращалась в сороку (см. Chevalier, Gheerbrant 1994, 553). 
В Корее с сороками связаны разные приметы. Например, считали, что если сорока кричит рано утром, то ожидается приятный гость, а если вечером - к несчастью. Если сороки станут вить гнезда к югу от дома, хозяин станет чиновником или получит повышение, если он уже чиновник (см. об этом Конрад 1996, 93).

Сорока встречается в сравнительных конструкциях:

«Красивая чистая одежда Ённи изорвалась, растрепались длинные косы, словно гнездо сороки стали» («Феи с Алмазных гор» 1991, 184); «...я, старуха, в семьдесят лет останусь без зятя и без дочери, словно клешня, брошенная сорокой с горы Тэбэксан» («Верная Чхун Хян» 1990, 75).

\section{Журавль}

Долголетие, мудрость, преданность и честь - символические значения, которыми наделяются журавли в Корее и Китае (Тресиддер 2001, 102; Chevalier,Gheerbrant 1994, 240). Корейские поэты называли свою родину - «страной бельх журавлей» (см. об этом Васильев 1976, 3).

В дальневосточных странах журавль почитается, как священная птица:

«Над гребнями Гор Алмазных // На самых крутых вершинах // Гнездится журавль священный, // Выводит своих птенцов» («Бамбук в снегу» 1978, 252).

По мифологическим представлениям народов Дальнего Востока, наравне с быстроногими скакунами журавли неизменно присутствовали в даосском раю. Из яиц этих священных птиц готовили пилюли бессмертия (см. об этом Сидихменов 2000, 177; Chevalier, Gheerbrant 1994, 240).

В дальневосточной мифологической традиции журавли переносят по воздуху небожителей, сопровождают умерших (см. об этом «Бамбук в снегу» 1978, 292). Это нашло отражение в литературе:

«...спускается к ней на журавле с небесной высоты прекрасная фея» («Подвижница Сим Чхон» 1990, 195); «Беседка над кручей рядом с луной; // Внизу, под скалой, вода. // То на веслах иду, то на шесте - // вверх и вниз по реке. // Кого журавли вознесли в небеса, // тот не вернется сюда» («Классическая поэзия...» 1980, 414).

Полагали, что фениксы и журавли, будучи посланцами небожителей, являются знатоками и тонкими ценителями музыки:

«Нет спору, музыка циньских дам красива, однако из древних книг нам ведомо, что фениксы начинают танцевать только после Девяти призывов Шуня, а если музыка не тронет небожителей, то фениксы танцевать не станут! Мы не можем сказать, какая из наложниц яньского князя играла искуснее, но мы явственно видели, как под их мелодию плясали белые журавли!» («Сон...» 1982, 554).

Журавль - птица, связанная с представлениями о бессмертном бытии: 
«Ты знаешь, я уже почти забыл, // Кто гость сегодня здесь, а кто хозяин. // Должно быть, господин долины этой, // И гор зеленых, и прозрачных рек - // Журавль, тот, что парит над нами, // Тот, кто нас ждет в Нефритовом Дворце! // И так хозяину промолвил странник: // А разве ты не из бессмертных сам?» («Бамбук в снегу» 1978, 267); «Журавли, //расскажите мне о былом» («Классическая проза Дальнего Востока» 1975, 288).

Журавль - элемент идеальной картины природы:

«В воде плещутся рыбки, а золотистые карпы, похожие на пиалы, радуются так, будто видят любимых, журавль в лунном сиянии страстно зовет подругу» («Верная Чхун Хян» 1990, 38); «Журавли, спящие среди цветов, взлетают, испугавшись шороха шагов» («Приключения зайца» 1990,334$)$.

Крики улетающих журавлей символизируют приход осени:

«Увядают травы, опадают листья, жалобно кричат улетающие журавли» («Черепаховый суп» 1970, 199).

Журавль выступает как цветовой образ:

«В своей черно-белой одежде // Парят журавли в поднебесье...» («Бамбук в снегу» 1978, 253); «В этот миг все кругом окуталось белыми облаками, среди которых парили попарно синие и белые журавли, фениксы и павлины» («Повесть о Сим Чхон» 1960, 243); «Снилось и мне кое-что прошлой ночью... Будто оседлал я желтоперового журавля, взлетаю на нем в небо...» («Повесть о фазане» 1960, 133).

Журавль - звуковой образ:

«...по саду гуляют поющие журавли» («История цветов» 1991, 591); «И разбудит меня, быть может, журавлиное курльканье, доносящееся бог весть откуда» («Повесть о зайце» 1960, 301).

Звучание корейского национального музыкального инструмента отождествляется с криком журавлей:

«Нын Пха достала пибу и тронула струны - звуки были чисты, они словно печалились и тосковали: казалось, будто ручей журчит в горной долине, будто кричат журавли высоко в небе...» (Ким Ман Чжун 1962, 324).

Журавль - символ уединения, друг отшельника, живущего среди «зеленых гор и синих рек» вдали от суетного мира. Журавль - одинокая, но общительная птица: бродит около дома отшельника, танцует, слушая его игру на цине (см. об этом Никитина 1994, 210).

«Мой дом стоит в предгорье Пэкхасана. // Кто станет среди гор его искать? // Меня лишь свежий ветер навещает, // Приходит в гости ясная луна. // Журавль у самого двора танцует... // Они ли мне не верные друзья?»; «В оконной раме из бамбука - ночь. // Луна восходит над оградой сада. // На семиструнном цине я играю, // Звук циня - как журчание 
воды. // И, слушает мою игру журавль // Пришел во двор и в плавном танце кружит» («Бамбук в снегу» 1978, 156;172); «...вдруг в воздухе раздался крик журавля и перед ним предстал отшельник» («Сказание о госпоже Пак» 1960, 499).

Журавль встречается в названиях. В Китае в руководстве по игре на цине, созданном в XVI веке, один из музыкальных приемов носит название «журавль таниует в пустынном саду». В живописной традиции Китая преемственность каллиграфического письма и природы засвидетельствована уже в самом названии некоторых из стильных штрихов: «следы журавлиного клюва» (см. Малявин 1995, 80; 122), а также «двойной журавль» («Золотая птица Гаруда» 1994, 23).

Журавли - любимый мотив дальневосточной живописи. Журавль запечатлен на многих картинах и апликациях, вышивках корейских мастеров разных эпох. В Китае изображение журавля, летящего к солнцу, - символ общественных устремлений, его белоснежное тело - чистоты, красная голова - огня жизни (см. Тресиддер 2001, 102).

В виде пожелания счастья на свитках были нарисованы десять символов долголетия - солнце, журавль и другие...» («Роза и Алый Лотос» 1974, 322).

Изображение журавля чаще всего встречается в отделке мебели, домашней утвари:

«...на столике - старинная бронзовая курительница, украшенная журавлем, сделанным из чистого золота» («Цветы сливы...» Т. 1 1998, 348).

Журавль - узор на одежде. Известно, что китайские священники под верхним облачением носили халат, украшенный спереди и сзади триграммами, а также изображением единорога и белых журавлей - символов бессмертия (см. Малявин 2000, 535-536).

«...талию подпоясали кушаком, расшитым журавлями» («Верная Чхун Хян» 1990, 46); «А бородатый в халате, расшитом парами журавлей...» («История цветов» 1991, 472).

На шлемах корейских воинов традиционно изображались драконы, фениксы и журавли:

«На боевом шлеме красовались дракон с фениксом и пара журавлей, собранная из золотых колец кольчуга походила на змеиную чешую, а поверх нее кровавым огнем горел усыпанный рубинами пояс» («Сказание о госпоже Пак» 1960,536$)$.

Платье из перьев журавля носили отшельники-даосы (см. Троцевич 1975, 189):

«Хэ Цин в головной повязке и в халате, убранном журавлинылми перьями, ночью вышел пешком из ворот лагеря» («Записки...» 1985, 209).

Образ журавля активно использовался в китайской кулинарии: в форме журавлей изготавливались пирожные (см. об этом Семанов 2000, 109). 
Журавль соотнесен с любовной тематикой:

«Протяжно курлыкал журавль, словно вспоминая о прежней любви» («Корейские повести» 1954, 187).

Журавль входит в состав образных сравнений при характеристике человека. Облик красавицы соотнесен с журавлем:

«Как женщины между собой не схожи... // Одна - журавль среди цветов и трав...» («Корейская классическая поэзия» 1956, 228).

Совершенно необычным может показаться русскоязычному читателю отождествление лица красавицы $с$ журавлем. Для русскоязычного читателя такая портретная характеристика является интеркультурной лакуной. Для носителя же корейского языка такое сравнение хоть и воспринимается, как устаревшее, однако оно понятно. В русской языковой ментальности при портретной характеристике человека журавль не вызывает у русских положительных ассоциаций (ср., например, журавлиная шея - о тонкой и длинной шее, журавлиные ноги - тонкие и длинные ноги, журавлиная походка - с выбрасыванием не согнутой в колене ноги).

«Утонченность ее личика напоминает образ журавля, играющего у голубой реки...» («Верная Чхун Хян» 1990, 30); «her neat face like $a$ crane under the snowy moon» (Kim Tae-kil 1990, 65).

Голос красавицы уподабливается крику журавля, парящего в облаках:

«Сом Воль подняла на мгновенье глаза, взор блеснул, как утренняя звезда, и будто сама собой полилась ясная песня, то журавль застонал в облаках...» (Ким Ман Чжун 1961, 76).

С журавлем сравнивается одинокая состарившаяся женщина:

«Но пройдут годы, и станешь ты вроде... одинокового журавля...» («Роза и Алый Лотос» 1974, 335).

Юноша также отождествляется с журавлем:

«Чхун Хян теперь принадлежит ему, и он, словно журавль, танцующий на самой высокой вершине Самгак, обеими руками осторожно взял нежные яшмовые ручки Чхун Хян...» («Верная Чхун Хян» 1960, 62).

Руки красавца соотносятся с крыльями журавля:

«Вот юноша взмахнул руками, словно журавль, танцующий в лучах заходящего солнца на самой высокой вершине горы Самгак...» («Верная Чхун Хян» 1990, 46).

Цвет волос пожилого человека отождествлен с перьями журавля:

«У него было молодое лицо и седые волосы, словно перья журавля» («Ссянъчхон кыйбонъ» 1962, 68).

У корейцев бытует представление о том, что журавль - энергичная птица, поэтому энергичный человек уподабливается журавлю:

«Хэ Цин видел, что князь Сюань бодр, как самый неугомонный журавль в стае...» («Записки...» 1985, 193).

Журавль встречается и в других сравнительных конструкциях: 
«...c голубого утуна звонкая капает прозрачная роса, словно журавль проснулся»; «Но Моннён... начал свою игру... Так одинокий журавль на пяти озерах с орхидеей в клюве играет у хижины пяти отшельников» («Верная Чхун Хян» 1990, 55;52); «Она <рыбья чешуя> порхает у дверей, а после тихо опускается на землю, как журавлиный пух» («Цветы сливы...» Т. 1 1998, 238).

Журавль отмечен в пословице:

«...Тю Тхэ Вон поддержал его: - А как же! Так и должно быть! Девка, видать, смышленная! Конечно, журавль мелкой птахе не пара!» (Ли Ги Ен 1958, 370).

Итак, как показали исследования, представители животного мира занимают важное место в переводных произведениях. Животные в художественных текстах выступают как разного рода эмблемы (напр., дракон - эмблема императорской власти, феникс - эмблема императрицы, изилинь - эмблема мира и хорошего правления); символы (черепаха символизирует долголетие, фениксы - супружеское счастье и т. д.); эталоны мужской и женской красоты (напр., феникс, журавль, дракон); различные знаки: зодиака (дракон, тигр); различия у военных и гражданских чинов (тигр, журавль); времен года (зеленый дракон - весны, феникс - лета, тигр - осени, черепаха - зимы); элементы идеальной картины природы (черепаха, журавль) и т. д.

В дальневосточном стереотипном мышлении за животными закрепляются определенные добродетели: дракон - одаренность, решительность, храбрость, ловкость; феникс - милосердие, человеколюбие, верность долгу, знание обрядов; иилинь - кротость, честность, доброта; черепаха - долголетие, выносливость и сила; журавль - долголетие, мудрость, преданность и честь. Образ тигра в дальневосточной традиции амбивалентен: за ним закреплены, как положительные качества (справедливость, порядочность, благородство, отвага, знание традиций, почтительность к родителям), так и отрицательные (свирепость, жестокость, хитрость).

Животные - неотъемлемая часть корейских и китайских мифов, легенд и поверий. Практически со всеми животными данной группы образованы речения фразеологического характера, они входят в состав образных сравнений, пословиц, поговорок. рока).

Некоторые животные стали национальными символами (тигр, со-

У всех представителей животного мира есть своя символика, которая придает национальный колорит переводным произведениям. 
1. Бамбук в снегу. Корейская лирика VIII-XIX веков. М.: Наука. Гл. ред. восточ. литер., 1978.

2. Би Сяошен. Цвет абрикоса. М.: СП «Вся Москва», 1992.

3. Братья Хынбу и Нольбу // Верная Чхун Хян. Корейские повести XVII-XIX веков. М.: Худож. литер., 1990. С.113-190.

4. Васильев Г. Белая цапля. М.: Изд-во «Наука». Главная ред. Восточ. литер., 1976

5. Верная Чхун Хян. Корейские повести XVII-XIX веков. М.: Худож. литер., 1990.

6. Гриффис В. Извлечение из сочинения «Corea the hermit nation».СПб.: Военная типография, 1884.

7. Ду Фу. Сто печалей. СПб.: «Кристалл», 2000

8. Зайчиков В. Т. Корея. М.: Географгиз, 1951.

9. Записки о добрых деяниях и благородных сердцах. Л.: Худож. литер. (Ленингр. отд.), 1985 .

10. Золотая птица Гаруда. Рассказы современных корейских писателей. СПб.: Центр «Петербургское Востоковедение», 1994.

11. История о верности Чхун Хян. Средневековые корейские повести. М.: Изд-во восточ. литер., 1960.

12. История цветов. Корейская классическая проза. Перевод с ханмуна. Л.: Худож. литер. (Ленингр. отд.), 1999.

13. Ким Г. Н. История религий в Корее. Алматы: Казак. ун-т, 2001.

14. Ким Ман Чжун. Облачный сон девяти. Роман. М.-Л.: ГИХЛ, 1961.

15. Ким Cu Cbın. Новые рассказы, услышанные на горе Золотой Черепахи. М.: Худож. литер., 1972.

16. Классическая поэзия Индии, Китая, Кореи, Вьетнама, Японии. М.: Худож. литер., 1977.

17. Классическая проза Дальнего Востока. М.: Худож. литер., 1975.

18. Книга прозрений. / Сост. В. В. Малявин. М.: Наталис, 1997.

19. Конрад Н. И. Неопубликованные работы и письма. М.:РОССПЭН, 1996.

20. Концевич Л. Р. Корееведение. Избранные работы. М.: И.Д. «Муравей-Гайд» 2001.

21. Корейская классическая поэзия. М.: Гос. Изд-во худож. литер., 1956.

22. Корейские повести. М.:ГИХЛ, 1954.

23. Корейские предания и легенды из средневековых книг. М.: Худож. литер., 1980

24. Корея. Карманная энциклопедия. М.:И.Д. «Муравей-Гайд», 2000.

25. Костенко А., Петушков И. Традиционный китайский календарь и прорицательные системы. Киев: Изд-во «София», 1999.

26. Ли Ги Ен. Земля. Роман. М.: Изд-во иностр. литер., 1958

27. Ли Ги Ен. Родная сторона. Роман. М.:Худож. литер., 1967.

28. Лим Чже. Мышь под судом. Повесть. М.: Худож. литер., 1964.

29. Малявин В. В. Китай в XVI-XVII веках. Традиция и культура. М.: «Искусство» 1995.

30. Малявин В. В. Китайская цивилизация. М.: Изд-во «Астрель», 2000.

31. Малявин В. В. Молния в сердце. М.: Изд-во «Наталис», 1997.

32. Мифы народов мира. Энциклопедияв двух томах. М.: Рос. энциклопедия, 1997.

33. Нефритовая роса. Из китайских сборников бицзи Х-ХІІІ веков. СПб.: Изд-во «Азбука», 2000.

34. Никитина М. И. Миф о Женщине-Солнце и ее родителях и его «спутники» в ритуальной традиции древней Кореи и соседних стран. СПб.: «Петербургское востоковедение», 2001.

35. Паукер Е. О. Корея. Бесплатное приложение к журналу «Живописное обозрение». СПб.: АО «Слово», 1904.

36. Повести страны зеленых гор. М.: Гос. изд-во худож. литер., 1966. 
37. Повесть о Сим Чхон // История о верности Чхун Хян. Средневековые корейские повести. М.: Изд-во восточ. литер., 1960.С.179-244.

38. Повесть о том, что приключилось с зайцем // История о верности Чхун Хян. Средневековые корейские повести. М.: Изд-во восточ. литер., 1960.С.288-322.

39. Повесть о Хынбу // История о верности Чхун Хян. Средневековые корейские повести. М.: Изд-во восточ. литер., 1960.С.408-490.

40. Повесть о Чёк Сёные (Чёк Сёный Чён) СПб.: ПФИВ РАН, 1996.

41. Поджио М.А. Очерки Кореи. Спб.: Тип. Е. Евдокимова, 1892.

42. Предания гор Кымгынсан. Пхеньян: Изд-ство литер. на иностр. яз., 1990

43. Пу Сун-лин. Рассказы Ляо Чжая о чудесах. СПб.: Изд-во Азбука», 1999.

44. Роза и Алый Лотос. Корейские повести (XVII-XIX вв.). М.: Худож. литер., 1974

45. Республика Корея. Путеводитель. ЗАО «Авангард», 2000.

46. Самозванцев А. М. Мифология Востока. М.: Изд-во «Алетейа», 2000.

47. Семанов В. И. Из наложниц в императрицы. М.: ИД «Муравей», 2000

48. Сидихменов В. Я. Китай: страницы прошлого. Смоленск: «Русич», 2000.

49. Сказание о госпоже Пак // История о верности Чхун Хян. Средневековые корейские повести. М.: Изд-во восточ. литер., 1960.С. 491-547.

50. Сказки народов мира. М.: Изд-во «Правда», 1987.

51. Скитания госпожи Са по югу // История о верности Чхун Хян. Средневековые корейские повести. М.: Изд-во восточ. литер., 1960. С.323-407.

52. Сон в нефритовом павильоне. Роман. М.: Худож. литер., 1982.

53. Сон Хён. Гроздья рассказов Ёнчжэ // Петербургское востоковедение. СПб.: Центр «Петербургское Востоковедение», 1994. Вып.5. С.25-109.

54. Ссянъчхон кыйбонъ (Удивительное слияние двух браслетов). М.: Изд-во восточ. литер., 1962.

55. Тресиддер Джек. Словарь символов. М.: Изд-во торг. дома «Гранд» и др., 2001.

56. Трочевич А. Ф. Корейская средневековая повесть. М.: Наука. Гл. ред. восточ. литер., 1975

57. Феи с Алмазных гор. Корейские народные сказки. М.: Худож. литер., 1991.

58. Хо Гюн. Достойный Хон Кильдон // Верная Чхунхян. Корейские классические повести XVII-XIX веков. М.: Худож.литер., 1990.

59. Цветы сливы в золотой вазе или Цзинь, Пин, Мэй. М.: Терра-книжный клуб. В 2-х томах. 1998.

60. Черепаховый суп. Корейские рассказы XV-XVII вв. Л.: Худож. литер., 1970

61. Шеппинг Д. С. Обозрение звериного эпоса Западной Европы. Материалы для сравнительного изучения русской символики животных // Филологические записки. 1869. Вып.1. С.1-14.

62. Chevalier Jean, Gheerbrant Alain. A Dictionary of Symbols. Cambridge: Blackwell Publishers, 1994,

63. Jober Gertrude. Dictionary of Mythology, Folklore and Symbols. New York: The Scarecrow Press.1962

64. Kim Tae-kil. Values of Korean People Mirrored in Fiction. Vol.1.Seoul: Dae Kwang Munwhasa, 1990.

65. Park Young-man. The Scent of Flowers. Seoul: Hankang publishing Company, 1999

66. Pratt Keith, Rutt Richard. Korea. A Historical and Cultural Dictionary. Great Britain: University of Durham, Curzon Press, 1999. 


\title{
Концепт «язык» в английской паремиологии
}

\author{
(С) Д. Ю. Полиниченко, 2004
}

Обобщение точек зрения на концепт и его определений в лингвистике позволяет прийти к следующему заключению: концепт - это единица коллективного знания/сознания (отправляющая к высшим духовным ценностям), имеющая языковое выражение и отмеченная этнокультурной спецификой [Воркачев 2001: 70].

Достаточно очевидно, что с термином «язык» (при всем многообразии его толкования) связан стержневой концепт языкознания. Язык составляет основной признак, выделивший человека из мира живой природы и придавший духовному началу физическое обличье. По В. Гумбольдту, «язык представляет собой беспрерывную деятельность духа, стремящуюся превратить звук в выражение мысли».

Естественный язык - своего рода «нерукотворный артефакт»: он возник и развился независимо от воли создавших его людей, и поэтому применительно к нему представляется оправданной «растительнобиологическая» метафора. В то же самое время как артефакт и одно из «измерений культуры» (Б. Малиновский) он почти исчерпывающе определяется своими функциями.

При помощи коммуникативной функции язык обеспечивает взаимодействие отправителя вербального (словесного) сообщения и его получателя, адресата. С другой стороны, язык направлен на действительность и на тот мир образов, который выстраивается между действительностью и человеком, выступая как множество знаний, образующих в совокупности картину, или модель, мира. Эта картина мира, локализованная в сознании, постоянно пополняемая и корректируемая, регулирует поведение человека. Язык не просто передаёт в актах коммуникации в виде высказываний сообщения, в которых содержатся те или иные знания о каких-то фрагментах мира. Он играет важную роль в накоплении знаний и их хранении в памяти, способствуя их упорядочению, систематизации, т.е. участвуя в их обработке.

Несмотря на то, что предпринимались попытки исследования лингвокультурного концепта «язык» в русском языковом сознании [Ромашко 1991; Макеева 2000; Степанов 2001], к настоящему времени в лингвистической литературе не существует описания английского лингвокультурного концепта «язык». В данной статье производится анализ реализации концепта «язык» в английской паремиологии.

В паремиологическом фонде языка хранятся специфические черты обыденного сознания этноса. Паремиологически отражённое знание, представленное в отдельных языковых системах, опирается на повседневный опыт людей как членов конкретных этнокультурных общно- 
стей, на традиции, обычаи и верования народов. Поэтому для обеспечения полноты исследования лингвокультурного концепта «язык» представляется необходимым проанализировать его паремиологическую реализацию.

Под паремиями понимаются устойчивые в языке и воспроизводимые в речи анонимные изречения, пригодные для употребления в дидактических целях [Савенкова 2002: 67]. Как правило, к паремиям относят пословицы и поговорки.

Логема (термин П. В. Чеснокова) - логико-семантическая единица обобщённого характера, под которую могут быть подведены отдельные группы паремий. Логема выступает в качестве обобщающей исходной мысли, объединяющей группы конкретных характеристик и оценок отдельных культурно значимых смыслов, выявляемых в паремиологическом фонде. Однако следует учитывать, что сведение паремий в логемы осуществимо только в общем виде вследствие возможности различных субъективных восприятий пословичной семантики [Савенкова 2002: 46, 112].

Материалом для исследования паремиологического представления концепта «язык» в английском языке послужили словари пословиц Р. Фергюссон [Fergusson 1995], Дж. Л. Апперсона [Apperson 1993], а также «Краткий оксфордский словарь пословиц» [CODP]. Корпус исследуемого паремиологического материала составил 63 паремии.

Основные суждения о языке, выраженные в английском паремиологическом фонде, могут быть сведены к 2-м общим логемам. В исследуемом материале эти логемы таковы:

1. Язык играет важную роль в жизни человека (35 паремий, 55,6 \%).

2. Языковая деятельность не обладает большой ценностью (28 паремий, 44,4\%).

Английские паремии, имеющие отношение к концепту «язык», могут быть рассмотрены в следующих аспектах:

1. Роль языка в жизни человека.

2. Отношение к языковой деятельности.

Аспект (1) «Влияние человека на окружающий мир при помощи языка» реализуется в логеме 1 «Язык играет важную роль в жизни человека». В принадлежащей этой логеме пословице The tongue is the rudder of our ship язык признаётся направляющей силой в жизни.

В логеме 1 можно выделить логемы низшего порядка 1.1 «Язык является инструментом достижения жизненных целей», 1.2 «Язык является источником опасности», 1.3 «Языковая деятельность является эффективным инструментом эмоционального воздействия», 1.4 «Хорошее владение языком означает умение хорошо сражаться», 1.5 «Язык выражает мысли человека» и 1.6 «При коммуникации язык должен быть понятен всем её участникам».

В логеме 1.1 «Язык является инструментом достижения жизненных целей» можно выделить две логемы низшего порядка: 1.1.1 «Без владе- 
ния языком невозможно добиться чего-либо» и 1.1.2 «Хорошее владение языком способствует достижению жизненных целей»

В паремиях логемы 1.1.1 содержатся мысли о том, что без владения языком невозможно достигнуть чего-либо в жизни (The lame tongue gets nothing; Dumb men get no lands).

При этом паремии логемы 1.1.2 утверждают, что, в свою очередь, использование языка помогает в жизненных достижениях (Spare to speak and spare to speed; Speak and speed, ask and have; The squeaking wheel gets the grease).

Логему 1.2 можно разбить на более конкретные логемы 1.2.1 «Язык опасен для окружающих» и 1.2.2 «Язык опасен для говорящего».

В паремиях, относимых к логеме 1.2.1, встречается прямое утверждение о том, что язык является оружием: A good tongue is a good weapon; Words cut more than swords; A woman's sword is her tongue, and she does not let it rust. Язык может ядовито жалить (The tongue stings; The tongue is more venomous than a serpent's sting; There is no venom to that of the tongue), наносить удары при помощи слов (Words are but wind, but blows unkind; Words may pass, but blows fall heavy), доводить до увечий и даже смерти (The tongue breaks bone, and herself has none; Under the tongue men are crushed to death).

Как язык является потенциальным источником опасности для окружающих, так является он им и для самого говорящего, поэтому в паремиях логемы 1.2.2 содержится призыв быть осторожнее в высказываниях во избежание отрицательных последствий (He that strikes with his tongue, must ward with his head; The tongue talks at the head's cost; Words bind men; A bleating sheep loses her bit; Let not your tongue run at rover; Let not thy tongue run away with thy brains; Better the foot slip than the tongue; Birds are entailed by their feet, and men by their tongues; Ox is taken by the horns, and a man by his tongue). Результат языковой деятельности невозможно изменить: A word and a stone let go cannot be called back.

В состав логемы 1.3 «Языковая деятельность является эффективным инструментом эмоционального воздействия» входят три паремии. В пословицах The voice is the best music и Good words cost nothing and are worth mисh утверждается безусловная ценность языковой деятельности, а в пословице Good words cool more than cold water выражен приоритет языковой деятельности над неязыковыми средствами.

Логема 1.4 «Хорошее владение языком означает умение хорошо сражаться» представлена пословицей He that speaks well, fights well.

Логема 1.5 «Язык отражает мысли человека» представлена паремиями What the heart thinks, the tongue speaks и Speech is the picture of the mind.

Язык высоко ценится как инструмент коммуникации: That is not good language which all understand not (логема 1.6 «При коммуникации язык должен быть понятен всем её участникам»). 
Логема 1.7 «Язык помогает скрывать истинные намерения» объединяет паремии $A$ honey tongue, a heart of gall и Fine words dress ill deeds.

Логема 1.8 «Язык трудно сдерживать» представлена единственной паремией He knows much who knows how to hold his tongue.

$\mathrm{B}$ английской паремиологии отчётливо выделяется пласт паремий, характеризующий пренебрежительное отношение к языковой деятельности и объединяющийся логемой 2 «Языковая деятельность не обладает большой ценностью», в которой реализуется аспект «Отношение к языковой деятельности». В паремиях, принадлежащих к данной общей логеме, языковая деятельность как процесс, с которого невозможно взять пошлину ввиду его малой ценности (Talking pays no toll), и как дешёвый товар (Talk is cheap). Высказывания, не подкреплённые делами, бесполезны: Good words without deeds are rushes and reeds.

Частной логемой общей логемы (2) является логема 2.1 «Языковая деятельность малоэффективна по сравнению с практической». В этой группе паремий языковая деятельность сравнивается с практической не в пользу первой. Результаты практической деятельности наглядны и обладают большей ценностью (Actions speak louder than words; An ounce of practice is worth a pound of precept; Example is better than precept; Deeds will show themselves, and words will pass away). Практическая деятельность оценивается выше языковой: Doing is better than saying; It is better to do well than to say well; A little help is worth a deal of pity. Дыхание, используемое при процессе говорения, лучше использовать подругому (Save your breath to cool your porridge).

Паремии логемы 2.2 «При помощи только языковой деятельности невозможно добиться практического результата» говорят о том, что языковая деятельность, в отличие от физической, не может навредить (Sticks and stones may break my bones, but words will never hurt me; Hard words break no bones); она бесполезна в качестве платёжного средства (Talk is but talk; but 'tis money buys land; Words pay no debts), и она не может заменить практическую деятельность либо материальные предметы (Fine (kind, soft) words butter no parsnips; Mere words will not fill a bushel; Fair words fill not the belly; Fair words will not make the pot play; He who gives fair words, feeds you with an empty spoon; Good words fill not a sack).

Паремия Easier said than done принадлежит логеме 2.2 «Языковая деятельность легче практической». К этой же логеме можно причислить паремии, в которых утверждается, что дела не всегда следуют за словами: There is great difference between word and deed; Saying and doing are two things; Saying is one thing, and doing another; From word to deed is a great space.

Логема 2.3 «Языковая деятельность не совместима с практической» объединяет паремии The greatest talkers are the least doers; Great barkers are no biters; Dogs that bark at distance bite not at hand. 
Таблица 1. Язык и языковая деятельность в английской паремиологии.

\begin{tabular}{|c|c|c|}
\hline № & Логема & $\begin{array}{l}\text { Кол-во } \\
\text { паремий }\end{array}$ \\
\hline 1 & 2 & 3 \\
\hline 1 & Язык играет важную роль в жизни человека & $34+1^{*}$ \\
\hline 1.1 & $\begin{array}{l}\text { Язык является инструментом достижения } \\
\text { жизненных целей }\end{array}$ & 5 \\
\hline 1.1 .1 & $\begin{array}{l}\text { Без владения языком невозможно добиться } \\
\text { чего-либо }\end{array}$ & 2 \\
\hline 1.1 .2 & $\begin{array}{l}\text { Хорошее владение языком способствует } \\
\text { достижению жизненных целей }\end{array}$ & 3 \\
\hline 1.2 & Язык является источником опасности & 20 \\
\hline 1.2 .1 & $\begin{array}{l}\text { Язык является источником опасности } \\
\text { для окружающих }\end{array}$ & 9 \\
\hline 1.2 .2 & $\begin{array}{l}\text { Язык является источником опасности } \\
\text { для говорящего }\end{array}$ & 11 \\
\hline 1.3 & $\begin{array}{l}\text { Языковая деятельность является эффективным } \\
\text { инструментом эмоционального воздействия }\end{array}$ & 3 \\
\hline 1.4 & $\begin{array}{l}\text { Хорошее владение языком означает умение } \\
\text { хорошо сражаться }\end{array}$ & 1 \\
\hline 1.5 & Язык отражает мысли человека & 2 \\
\hline 1.6 & $\begin{array}{l}\text { При коммуникации язык должен быть понятен } \\
\text { всем её участникам }\end{array}$ & 1 \\
\hline 1.7 & Язык помогает скрывать истинные намерения & 2 \\
\hline 1.8 . & Язык трудно сдерживать & 1 \\
\hline 2 & $\begin{array}{l}\text { Языковая деятельность не обладает большой } \\
\text { ценностью }\end{array}$ & $26+2 *$ \\
\hline 2.1 & $\begin{array}{l}\text { Языковая деятельность малоэффективна } \\
\text { по сравнению с практической }\end{array}$ & 8 \\
\hline 2.2 & $\begin{array}{l}\text { При помощи только языковой деятельности } \\
\text { невозможно добиться практического результата }\end{array}$ & 10 \\
\hline 2.3 & Языковая деятельность легче практической & 5 \\
\hline 2.4 & $\begin{array}{l}\text { Языковая деятельность несовместима } \\
\text { с практической }\end{array}$ & 3 \\
\hline
\end{tabular}

*За знаком «+» указано количество паремий, которые могут быть подведены под общую логему, но не подводятся под перечисляемые частные логемы. 
Представление о языке в английском паремиологическом фонде характеризуется нерасчленённостью понятий «язык» и «языковая деятельность». Лексема tongue в паремиях, совершенно аналогично русской лексеме язык, указывает на орган речи, через функционирование которого описывается языковая деятельность. Представление о языке как о системе знаков и словарно-грамматических средств в английской паремиологии практически отсутствует; единственным исключением является пословица That is not good language which all understand not, причем для выражения понятия используется слово language, которое в значении «органический язык» не употребляется.

Наличие сигнальной лексемы (в данном случае лексем tongue и language) в составе паремии не является обязательным условием для связи её с определённым концептом (см. [Савенкова 2003: 260]). Из 63 исследованной паремии 19 (30 \%) содержат лексему tongue, 22 паремии (35 \%) - лексему word. Лексемы language и speech представлены каждая одной паремией. Языковая деятельность выражается при помощи глаголов речи to say (4 паремии) и to speak (4 паремии).

В английских паремиях язык выступает как могущественный инструмент воздействия на окружающий мир, обладающий высокой ценностью (логема 1). Вместе с тем, его деятельность зачастую малоэффективна, особенно по сравнению с практической деятельностью (логема 2).

В английских паремиях функции языка как инструмента сводятся прежде всего к приобретению материальных ценностей (Dumb men get no lands; Speak and speed, ask and have), что отражается в логеме «Язык является инструментом достижения жизненных целей». Это свидетельствует об относительно большой значимости материальных благ для английского языкового сознания, что коррелирует с данными этнопсихологии: «Одна из главных жизненных ценностей для англичан - материальное благополучие» [Крысько 2002: 197], «Деньги - кумир англичан. Ни у кого богатство не пользуется таким почётом. Каково бы не было общественное положение человека в Великобритании, ..., он прежде всего - коммерсант. ... Его первая забота всегда и везде - нажить как можно больше» [Сухарев-Сухарев 1997: 104], «Поражает неистовая одержимость, с которой американцы работают, т.е. делают деньги» [Крысько 2002: 193].

Английскому языковому сознанию, очевидно, чуждо представление об автономности, самостоятельности языка. Это также соответствует этнопсихологическим наблюдениям: англичане жестко контролируют страсти своего темперамента, и английские традиции предписывают сдержанность в словах [Сухарев-Сухарев 1997: 101, 109]. 
Английскому языковому сознанию свойственно сравнение языка с оружием ( $A$ good tongue is a good weapon; Words cut more than swords), равно как и представление о гендерной маркированности языка ( $A$ woman's sword is her tongue, and she does not let it rust).

Как видно из анализа английских паремий, имеющих отношение к концепту «язык», в паремическом представлении язык наделён противоречивыми качествами. Логемы 1 и 2 во многом противоречат друг другу. Но это представляется закономерным, так как все подлинные народные пословицы дают в своей сумме многосторонний взгляд на жизнь, синтез высокого и низкого, начал добра и зла, единство тезисов и антитезисов [Хлебда 1994: 83]. По определению Станислава Ежи Леца, «пословицы противоречат друг другу. И в этом именно народная мудрость».

Концепт, как правило, включает в себя определённые коннотации (см. [Красных 2002: 185]). Из анализа английского паремиологического фонда можно сделать вывод, что язык получил в основном отрицательные коннотации в английском языковом сознании.

Анализ английского паремиологического фонда позволяет сделать следующие выводы. Представление о языке в английской паремиологии, характеризуется нерасчленённостью понятий «язык» и «языковая деятельность» и практическим отсутствием представления о языке как о системе знаков и словарно-грамматических средств. В английской паремиологии утверждается важность языка в жизни человека и вместе с тем невысокая ценность языковой деятельности; язык представляется инструментом для достижения целей. Для английского языкового сознания не характерно представление о языке как об автономном, независимом органе, наделённом определёнными качествами. Одновременно анализ английских паремий позволяют сделать вывод об относительно большой значимости материальных благ для английского языкового сознания, что коррелирует с данными этнопсихологии.

$$
\text { Литер атура }
$$

1. Воркачев С. Г. Лингвокультурология, языковая личность, концепт: становление антропоцентрической парадигмы в языкознании. // НДВШ 2001. № 1. С. 64-72.

2. Kpacных B. B. Этнопсихолингвистика и лингвокультурология: Курс лекций. М.: ИТДГК «Гнозис», 2002. - $284 \mathrm{c.}$

3. Крысько В. Г. Этническая психология. - М.: Издательский центр «Академия», 2002. $-320 \mathrm{c}$.

4. Макеева И. И. Языковые концепты в истории русского языка // Язык о языке: Сб. статей. - М., 2000. С. 63-155.

5. Ромашко С. А. «Язык»: структура концепта и возможности развертывания лингвистических концепций. // Логический анализ языка. Культурные концепты. - М., 1991.

6. Савенкова Л.Б. Русская паремиология: семантический и лингвокультурологический аспекты. - Ростов н/Д: Изд-во Рост. Ун-та, 2002. - 240 с. 
7. Савенкова Л. Б. Языковое воплощение концепта // Проблемы вербализации концептов в семантике текста: Материалы междунар. симпозиума. Волгоград, 22-24 мая 2003 г.: в 2 ч. - Ч. 1. Научные статьи. Волгоград: Перемена, 2003. - С. 258 - 264.

8. Степанов Ю. С. Константы: словарь русской культуры. М., 2001.

9. Сухарев B. А., Сухарев М. В. Психология народов и наций. - Д.: Сталкер, 1997. - 400 c.

10. Хлебда В. Пословицы советского народа. Наброски к будущему анализу. «Русистика». - Берлин, 1994, № 1/2. - С. 74-84.

11. Apperson G. L. The Wordsworth Dictionary of Proverbs. - Wordsworth Edition Ltd, 1993.

12. CODP - The Concise Oxford Dictionary of Proverbs. Oxford, New York. Oxford University Press. Third edition, 1998

13. Fergusson Rosalind. The Penguin Dictionary of Proverbs. Over 6000 proverbs. - London: Claremont Books, 1995. 


\title{
К определению понятия «языковые маркеры национально-культурного сознания»
}

\author{
(C) кандидат филологических наук И. В. Привалова, 2004
}

Изучение национально-культурной специфики языкового знака имеет давние традиции в отечественной филологической науке и отмечено разнообразием подходов. Руководствуясь практической необходимостью оптимизации процесса преподавания русского языка, Е.М. Верещагин и В.Г. Костомаров выделили «лингвострановедческие единицы», в которых прозрачна совокупность сведений о культуре страны, как то: безэквивалентная лексика, коннотативная лексика, устойчивые речевые формулы, невербальные средства коммуникации, реалии, фоновые знания и т. д. ${ }^{1}$ В последующих работах основоположников лингвострановедения как самостоятельной области компаративного языкознания гипотетическое сопоставление языковых единиц проводилось с целью изучения проникновения культуры в семантику языковой единицы, при этом основное внимание уделялось, прежде всего, лексеме. Авторы объясняли это следующим образом: «...слово как отдельная языковая единица вмещает в себе и в себя знания о действительности, свойственные как массовому, так и индивидуальному сознанию» ${ }^{2}$.

Первые лингвострановедческие работы были направлены на изучение специфики отдельных культурно-маркированных единиц русского языка, совокупность которых и составляла «страноведческие знания», без учета конкретного адресата, т. е. той этнолингвокультуры, с которой проводились сопоставления. Однако практика преподавания русского языка как иностранного показала, что необходима культурно-адресная семантизация, что повлекло за собой появление сопоставительных лингвострановедческих работ, и, как следствие, оформление отдельной научной дисциплины - сравнительного лингвострановедения. Основным предметом сравнительного лингвострановедения, по мнению А.С. Мамонтова, является «... национально-культурная специфика материальной и духовной культуры, находящая отражение в семантической структуре единиц изучаемого и родного языков и проявляющаяся в процессе овладения иностранным языком как средством межкультурного общения» ${ }^{3}$. Очень важным моментом в работе А.С. Мамонтова является то, что в качестве мате-

\footnotetext{
${ }^{1}$ Верещагин Е. М., Костомаров В. Г. Язык и культура. Лингвостнрановедение в преподавании русского языка как иностранного. М.: Русский язык, 1973.

2 Верещагин E. M., Костомаров В. Г. Лингвострановедческая теория слова. М. Русский язык, 1980. С. 192.

${ }^{3}$ Мамонтов $A$. C. Язык и культура: сопоставительный аспект изучения. М.: Советский писатель, 2000. С. 116.
} 
риала исследования рассматривается достаточно широкий, но, с нашей точки зрения, еще не предельно оптимальный спектр: лексический, фразеологический и афористический уровни и соответствующие единицы, содержащие культурный компонент; формы речевого этикета, невербальные средства коммуникации, отмеченные национально-культурной маркированностью; художественный текст - феномен национальной культуры, а также национальная (этническая) психология как субстрат речевого и неречевого поведения 4 . Выделение сравнительного лингвострановедения в самостоятельное научное направление способствовало методологической конкретизации таких наук как лингвострановедение, лингвокультурология, этнопсихолингвистика и межкультурная коммуникация.

«Лингвострановедческая теория слова» инициировала, с одной стороны, появление лексикографических изданий лингвострановедческого типа, а с другой стороны, лингвокультурологических работ, в которых рассматриваются различные аспекты воплощения и проявления национальной культуры в языке. Работы В.В. Воробьева внесли существенный вклад в оформление лингвокультурологии как самостоятельной научной дисциплины, «изучающей взаимосвязь и взаимодействие культуры и языка в его функционировании и отражающей этот процесс как целостную структуру в единстве их языкового и внеязыкового (культурного) содержания...». Различаются собственно языковые единицы и лингвокультуремы, в которых помимо обычных составляющих (знак - значение) прибавляется культурно-понятийный компонент, как совокупность «культурного ореола». Набор лингвокультурем образует лингвокультурологическое поле, которое «дает для определенного народа свою «картину мира», а сопоставление таких «картин мира» у разных народов вырисовывает сходства и различия в их языках и культурах» ${ }^{7}$. Предложенные положения подкреплены практическими исследованиями языкового материала, в качестве которого выступают лингвокультурологические поля «французская национальная личность» и «русская национальная личность». В них входят формы национального сознания, закрепленные в номина-структурах, представляющих собой лексические единицы, содержащие фоновые семантические доли, отражающие национальный смысл.

Созвучны понятию «лингвокультурема» предложенные В.И. Шаклеиным термины «лингвокультурологема» и «лингвоидеологема», которые описывают единицы, являющиеся составляющими лингвокультурного универсума и лингвокультурной ситуации. Через рассмотрение действие механизма номинации и предикации языковых единиц лек-

${ }^{4}$ Указ. соч. С. 117

${ }_{5}^{5}$ Воробьев В. В. Культурологическая парадигма русского языка. М., 1994. С. 24.

${ }^{6}$ Указ. соч. С. 33.

7 Указ. соч. С. 24. 
сического уровня доказывается постулат об оценочно-аксиологическом факторе моделирования ситуативного мировидения ${ }^{8}$.

В работах другого видного лингвокультуролога - В.А. Масловой также подчеркивается действенная функция языка как культурного кода нации, который «не только отражает реальность, но интерпретирует ее, создавая особую реальность, в которой живет человек» ${ }^{9}$. Как предметы исследования в лингвокультурологии выделяются: слова и выражения, служащие предметом описания в лингвострановедении, безэквивалентные языковые единицы, мифологизированные языковые единицы (архетипы, мифологемы, обряды, поверья, ритуалы, обычаи, закрепленные в языке), паремиологический и фразеологический фонды языка; эталоны, стереотипы, символы; стилистический уклад, речевое поведение и речевой этикет. Исследование содержит уникальный материал сопоставительного изучения близкородственных языков, относящихся к славянской группе. Однако по анализу языкового материала не всегда понятно, по каким критериям определенное явление квалифицируется как содержащая культурный фон языковая единица, или как культурный знак, или как когнитивная структура (например, в случае со стереотипом, эталоном, метафорой и образом).

С нашей точки зрения, когда речь идет о сопоставлении лингвокультур в соответствии с параметрами антропоцентрического подхода (а лингвокультурологический подход представляется именно таковым), то следует говорить о национально-культурной маркированности всей языковой системы, а не отдельных ее единиц. На современном этапе развития компаративных исследований антропоцентрической направленности нет единства мнений относительно того, что следует рассматривать в качестве объекта и предмета исследования лингвокультурологии, сравнительного лингвострановедения и этнопсихолингвистики. Поскольку эти парадигмы восходят к единому научному «истоку» (исследования В. Гумбольдта, Э. Сепира, Б. Уорфа, А.А. Потебни) и базируются на посылке детерминационного единства языка, сознания, этноса, культуры, то можно говорить об общности их материала исследования, которым должен являться весь комплекс национально-маркированных языковых единиц. Но предмет, объект, цели и задачи у каждого научного направления особые: в лингвокультурологии акцентируется внимание на взаимодействии языка и культуры, сравнительное лингвострановедение включен методический аспект, а этнопсихолингвистика инкорпорирует изучение психологической и когнитивной составляющих.

Попутно отметим, что описанные лингвострановедческие и лингвокультурные единицы объединяет то, что, в основном, это знаки лекси-

\footnotetext{
${ }^{8}$ Шаклеин В. М. Лингвокультурная ситуация и исследование текста. М.: Об-во любителей русской словесности. 1997.

${ }^{9}$ Маслова В. А. Лингвокультурология. М.: Академия. 2001. С. 3.
} 
ческого уровня с «прикрепленной» культурной информацией, как-то: «национально-культурная реалия» ${ }^{10}$, «этноэйдолексема» ${ }^{11}$, «логоэпистема» ${ }^{12}$ и т. д. Анализируя особенности «новояза» постперестроечного периода, В.Г. Костомаров и Н.Д. Бурвикова предлагают понятие «логоэтистема», обозначающую информативную свертку текста. «Речь идет о знании, несомом словом как таковым - его скрытой «внутренней формой», его индивидуальной историей, его собственными связями с культурой» ${ }^{13}$.

Исследование национально-культурного аспекта номинации представляет собой еще один интересный подход, продуцирующий данные, которые способствуют пониманию закономерностей влияния культуры на означивание предметов и явлений объективной действительности. Изучение специфики механизма номинации в национально-культурном аспекте помогает понять не только особенности наименования объекта с учетом его принадлежности той или иной лингвокультуре, но и соотношение семантики с феноменом культуры вообще. Методика выявления национально-культурной специфики языка через изучение внутренней формы производного слова предлагается Т.И. Вендиной. Полагая, что словарный состав во многом определяется архетипом языкового сознания народа, автор данной гипотезы считает, что «язык культуры» есть не что иное, как результат процесса смыслообразования, при котором смыслы опредмечиваются, застывая в завершенных номинаструктурах. «Так как в любом языке словообразовательно маркируется то, что является биологически, социально или культурно значимо в сознании народа, то можно предположить, что словотворческий акт определенным образом организует смысловое пространство языка, обусловливая отбор значимых фактов и устанавливая наличие между ними связи» ${ }^{14}$. Внутренняя форма слова, проявляющая тот признак, который ложится в основу названия, действительно может играть важную роль для выяснения национальных особенностей семантики слова. Например, в русском языке признак «кривой», «извилистый» лег в основу наименований отрицательных характеристик поведения человека, выраженных идиомами «кривить душой», «вилять». Но мотивированная лексика составляет незначительную часть от общего словаря любого современного языка, а обсуждение соотношения немотивированного и иконического (мотивированного) элементов

\footnotetext{
${ }^{10}$ Влахов С., Флорин C. Непереводимое в переводе. Реалии // Мастерство перевода. М.: Сов. писатель. 1970. С. 432-456.

${ }^{11}$ Шейман Л. А. Научные основы курса русской литературы в кургызской школе. Автореф. д-ра пед. наук в форме научного доклада. Бишкек. 1994.

${ }^{2}$ Костомаров В. Г., Бурвикова Н. Д. Современный русский язык и культурная память // Этнокультурная специфика речевой деятельности: Сб. обзоров / РАН ИНИОН. М. 2000.

${ }^{13}$ Указ. соч. С. 28.

${ }^{14}$ Вендина Т. И. Словообразование и «сокрытые смыслы» языка культуры // Вестник МГУ. Сер. 19. Лингвистика и межкультурная коммуникация. 2001. № 2. С. 16. 
внутри одного лингвистического знака восходит к полемике о происхождении имен, которая имеет как именитых сторонников, ратующих за происхождение имен «от природы» (Платон, Лейбниц, Ферс, Якобсон и т. д.), так и именитых оппонентов, оспаривающих этот факт (Аристотель, Соссюр, Хомский и т. д.).

Огромный вклад в исследование национально-культурной специфики языковых единиц внесли сотрудники института языкознания РАН Ю.С. Степанов, Н.Д. Арутюнова, В.Н. Телия, Е.Ф. Тарасов, Ю.А. Сорокин, Н.В. Уфимцева и др. Их работы явились основополагающими и определяющими для развития современной отечественной лингвокультурологии, сравнительного лингвострановедения и этнопсихолингвистики. Исследования Ю.С. Степанова посвящены описанию констант культуры в диахроническом аспекте, поскольку анализ их содержания проводится с привлечением текстов различных времен ${ }^{15}$. Научные интересы Н.Д. Арутюновой сконцентрированы на изучаемых также в диахроническом аспекте универсальных терминах культуры, извлекаемых на основе сопоставления текстов - продуктов различных лингвокульту ${ }^{16}$. В.Н. Телия и ее ученики исследуют культурную семантику фразеологических единиц с позиции рефлексии носителя языка, т. е. в сихроническом и антропоцентрическом аспекте.

Рассматривая культурно-национальную специфику фразеологических единиц, В.Н. Телия обосновывает понятие культурной коннотации как интерпретацию денотативного или образно мотивированного аспекта значения в категориях культуры. Концепция В.Н. Телия базируется на гипотезе, объясняющей воплощение культурной коннотации в содержание языкового знака: культурно-национальная специфика языковой единицы служит «звеном», соединяющим в единую цепь «тело знака» и знаки культуры - концепты, стереотипы, эталоны, символы, мифологемы и т. п. Средством воплощения культурно-национальной специфики в их знаковую организацию служит образное основание, а способом указания на специфику является интерпретация образного основания в знаковом культурно-национальном «пространстве» данного языкового сообщества, которая и составляет содержание культурно-национальной коннотации ${ }^{17}$. Исследование В.Н. Телия представляет собой не анализ отдельных языковых явлений, объединенных общими признаками, а разработку теоретической модели, позволяющей представить различные аспекты значения языкового знака в лингво-когнитивно-культурологической парадигме, а также дать характерологическое описание ситуаций и условий, позволяющих языковым знакам выполнять роль культурных феноменов.

\footnotetext{
1997.

${ }^{15}$ Степанов Ю. С. Константы. Словарь русской культуры. Опыт исследования. М.:

${ }^{16}$ Арутюнова Н. Д. Язык и мир человека. М.: Языки русской культуры. 1999.

${ }^{17}$ Телия В. Н. Русская фразеология. Семантический, прагматический и лингвокультурологический аспекты. М.: Языки русской культуры. 1996. С. 214-215.
} 
Приведем принципиально важные постулаты концепции В.Н. Телия, которые стали «навигационными» при выработке теоретических основ и для разработки понятия «языковые маркеры национально-культурного сознания». При изучении национально-культурной специфики за исходное принимается национальный язык в его идиоэтнических формах, а не отдельные языковые факты, где и усматриваются идиоэтнические черты. Описание культурно-национальной специфики отдельного языкового явления проводится на широком теоретическом фоне, связанном с взаимоотношениями языка и культуры как двух семиотических систем. (Теоретическим фоном нашего исследования является положение об этнолингвокультурном сознании и его овнешнениях как инструментах анализа специфики МКО). Национально-культурная специфика идиом, безусловно, представляет собой наиболее яркий иллюстративный материал культурно-языковой соотносительности, однако, культура присутствует не только за системой значений образно мотивированных номинативных единиц, но и за системой и структурой всего языка. Наконец в воплощении культурных фактов в семиотическом коде усматривается культурнообусловленное восприятие объективно существующего образа мира, определяющее мировидение, и далее - миропонимание представителей определенного этнолингвокультурного сообщества.

Таким образом, в большинстве лингвострановедческих и лингвокультурологических исследованиях изучаются лексемы, содержащие культурно-маркированные семантические доли, т.е. узаконивается вхождение непонятийного представления в состав слова. Понятие языковые маркеры национально-культурного сознания (далее - ЯМНКС) подразумевает включенность национально-культурных знаний не только в денотативно-коннотативную структуру языкового знака, а в структуру языка и его единиц в виде пропозиций и фоновых знаний, принадлежащих этонолингвокультуному сознанию языковой личности. Пропозиция понимается нами как «отражающей некие онтологически существующие отношения между предметами или предметом и его свойством и осмысленные как таковые в голове человека» ${ }^{18}$.

Образ мира, универсальный в своей первозданности меняется от одной культуры к другой, поскольку в процессе восприятия человеком в структуре деятельности общения явления реальной действительности специфически фиксированы причинными и пространственными связями. Этнолингвокультурным сознанием определенного сообщества задается программа коммуникативного поведения языковой личности. Введение понятия ЯМНКС как овнешнителей образов этнолигвокультурного сознания представляет возможность анализировать межкультурные аспекты языкового сознания и этнокультурную специфику образов сознания. Лю-

${ }^{18}$ Краткий словарь когнитивных терминов. / Под общ. ред. Е. С. Кубряковой. М.: Изд-во Московского университета. 1996. С. 138. 
бое изменение образа мира, неизбежно происходящее в процессе развития этноса, отображается и фиксируется в ЯМНКС, что позволяет выделять парадигматический и синтагматический аспекты.

Следует заметить, что предположение о необходимости изучения образов сознания и структур языкового сознания при исследовании несущих национально-культурную информацию языковых единиц высказывались в ряде лингвострановедческих работ. Так Г. Крабб предлагал наряду с исследованием национально-маркированных языковых единиц учитывать особенности структур сознания индивида как представителя определенной этнокультуры ${ }^{19}$. В.В. Ощепкова, классифицируя культурологические, этнографические и типологические аспекты лингвострановедения, подвергла сопоставительному анализу облигаторные национальноокрашенные образы в различных вариантах английского языка, при этом, оставив без определения, само понятие «национального словесного образа» и механизмы его структурирования в «национальный образ мира» ${ }^{20}$.

Понятие ЯМНКС подразумевает рассмотрение не одного, отдельно взятого языкового знака, обладающего национально-культурной спецификой, но продуктов речевой деятельности моно-, би-, полилингвальной языковой личности - представителя определенного этнолингвокультурного сообщества. Вследствие этого ЯМНКС являются предметом антропоцентрической парадигмы лингвистики, и как части ее - этнопсихолингвистики. Введение термина ЯМНКС позволяет не только выявлять национально-культурную специфику отдельных единиц, но определить национально-культурную специфику всей языковой системы как инструментария, которым пользуется языковая личность, для происходящего в виде вербальной интерпретации овнешнения своих образов сознания.

Наличие целостной теоретической основы - понимание ЯМНКС как овнешнителей образов этнолингвокультурного сознания, где язык и культура являются формами существования общественного сознания - фактор, благоприятствующий сознанию единой таксономии ЯМНКС, способной быть экстраполированной на любые контактирующие, а значит, и сопоставляемые этнолингвокультуры.

19 Крабб Г. Методика предупреждения трудностей восприятия национальнокультурной специфики русского художественного текста в процессе обучения ганских студентов-филологов. Автореф... канд. пед.наук. М. 1991.

${ }^{20}$ Ощелкова В. В. Культурологические, этнографические и типологические аспекты лингострановедения. Автореф...д-ра филолог. наук. М. 1995. 


\title{
Философия поступка М. Бахтина как феноменология необязательного действия
}

\author{
(C) А.И. Калыгин, 2004
}

Попытка описания, феноменологии, долженствующе поступающего сознания - главная задача первой, собственно философской, работы Михаила Бахтина, условно названной издателями «К философии поступка» [1]. Работа осталась незавершенной; тем не менее, имея в наличии данный текст, правомерно поставить вопрос: насколько справился Бахтин с поставленной задачей? По прочтении этой работы появляется двойственное чувство. С одной стороны, поражает глубина интроспективного анализа человеческого сознания, но, с другой стороны, не покидает ощущение неполноты, нехватки чего-то существенного в описании специфически долженствующих действий.

Настоящая статья и будет попьткой ответить на этот вопрос.

В ней мы вначале представим наше понимание долженствования и те необходимые пред-посылки, которые позволяют оценивать какоелибо действие субъекта именно как долженствующее. Далее, руководствуясь этими критериями, мы покажем, что в бахтинском описании долженствующих действий, в его терминологии - поступков, отсутствует по крайней мере одна из этих пред-посылок. Следствием чего будет наш вывод о том, что поступки суть действия всего лишь необратимые, но не долженствующие. В конце статьи мы попытаемся найти ту причину, по которой Бахтин так и не дошел до понимания специфики долженствующих действий, укажем на то, что помешало ему построить действительную феноменологию поступка.

Итак, посмотрим, что выражает понятие долженствования в русском языке, то есть в каких случаях, по отношению к каким будущим действиям субъекта, употребляется слово «должен». Мы это сделаем для того, чтобы появился своеобразный фон, ориентир, который не позволит нам запутаться и потеряться в лабиринтах бахтинской мысли.

Долженствование, которое субъект относит к самому себе, в русском языке обычно выражает для него необходимость, обязательность предстоящего действия, причем необходимость, имеющую характер вынужденный, принуждающий субъекта поступать именно так, а не иначе.

Приведем примеры из разных областей функционирования слова «должен». 
Из области права: «Я, как гражданин этого государства, должен соблюдать все законы этого государства».

Из области морали: «Я должен помочь ему, потому что обещал».

Религиозные заповеди: «Ты должен почитать отца своего и мать свою».

Из бытовой сферы: «Обстоятельства сложились так, что я должен буду уехать».

Из области познания: «Чтобы доказать это, я должен руководствоваться законами логики».

Общим моментом всех этих высказываний является наличие в сознании действующего субъекта, выражаясь языком психологии, отрицательной мотивации. Она означает, что побудительным мотивом такого рода действий будет стремление избежать нежелательных последствий, которые с неизбежностью наступят при выборе действия иного, чем требуется в данном высказывании. Именно стремление субъекта избежать применения к нему своего рода санкции, не подвергнуться определенному наказанию - со стороны закона, совести, Бога, природы, методов познания - и дает субъекту чувство обязательности, неслучайности в выборе. Чувство, возникающее у субъекта, находящегося в плане долженствования, можно выразить одной фразой: «Не очень хочется это делать, но придется, иначе будет хуже».

Руководствуясь данной схемой, к выше приведенным высказываниям мы можем добавить поясняющие части:

«Мне не очень хочется исполнять все законы, но придется, иначе я подпаду под санкции исполнительной власти».

«Мне не хочется помогать ему, но придется, иначе совесть будет мучить меня».

«Мне не всегда удается почитать своих родителей, но я вынужден это делать, иначе Бог накажет меня».

«Я не хочу уезжать, но мне придется это сделать, иначе, в связи со сложившимися обстоятельствами, я понесу большой ущерб».

«Мне не очень хочется выстраивать строгие логические цепочки в системе доказательств, но мне придется это сделать, иначе я не смогу доказать убедительно свою правоту».

По всей видимости, логические объемы долженствующих действий и действия с отрицательной мотивацией совпадают.

Могут возразить, что не все действия с долженствованием совершаются на фоне чувства «не хочется, но должен», приводя такой пример: «Я должен поехать туда потому, что хочу увидеть ее». Аргументация здесь такова: желание обрести то, что хочется, - «хочу увидеть» относится к случаю не отрицательной, а положительной мотивации в выборе предстоящего действия. Однако если присмотреться и сравнить 
выше приведенное высказывание с похожим высказыванием «Я хочу поехать туда потому, что хочу увидеть ее», то можно отметить, что фраза с долженствованием субъектом произносится только тогда, когда желание увидеть очень сильное и в каком-то смысле непреодолимое. Как раз непреодолимость своего же желания и вынуждает действовать. Субъект знает, что если он не сделает это, то желание не оставит его в покое. Это желание, по причине своей интенсивности, - вне его власти. Здесь - полная аналогия с независимостью от человека голоса совести, а значит, и в этом случае долженствование - действие, отрицательно мотивированное.

Теперь выделим три конституционных пред-положения, имплицитное наличие которых и делает долженствующее действие собственно долженствующим, то есть для субъекта вынужденно обязательным.

Первым пред-посылаемым моментом любого долженствующего действия и, шире, - любого действия, которое субъект собирается осуществить, является, очевидно, обладание субъекта свободой выбора будущих действий. Правда, здесь - в плане долженствования - свобода человека оценивается со знаком минус, то есть как возможность выбора не того, что необходимо, не того, что обязательно необходимо сделать. Оценка такой свободы в корне отличается от оценки свободы в творчестве - свободы как истока появления чего-то абсолютно нового, и именно этой возможностью новизны оцениваемая самим субъектом положительно. В долге же свободы, по идее, быть не должно, но она есть, и с этим приходится считаться. Долженствование как бы ищет способ, каким образом вынудить субъекта поступить так, а не иначе, принудить его делать то, что требуется? Только через предупреждение о неизбежности наказания. Страх перед применением конкретных санкций и призван принудить субъекта к определенным действиям. И чем сильнее переживается нежелание наступления отрицательных последствий, тем обязательнее предстают перед человеком предстоящие необходимые действия. В свою очередь степень угрозы зависит не только от меры наказания, но и от оценки степени неизбежности его наступления. Конечно, субъект может поступить иначе, чем требует от него эта долженствующая необходимость, - допустим, исходя из какого-то принщипа (например, назло себе или другим) - но он абсолютно точно знает, что будет наказан за это. Поэтому такого рода принциииальныле поступки, несмотря на их противоположную направленность требуемым действиям, оставляют человека в долженствующем плане. Но почему же субъект не может оправдаться и избежать наказания за свое ослушание, за свои не такие действия?

На этот вопрос отвечает второй конституционный элемент долженствующих действий, а именно: уникальность и необратимость 
каждого пространственно-временного момента, в котором субъект находится; этого здесь-и-сейчас, когда необоримо звучит в его сознании, так сказать, зов долга. Пространственная составляющая - употребляя терминологию Бахтина - долженствующего хронотопа делает невозможным одновременное нахождение субъекта в двух разных точках бытия. Что касается временного компонента, то для долженствования важна необратимость временных событий, их невозвратность: то, что сделать предстоит, исправить будет невозможно. Очевидно, что эти свойства пространства-времени суть фундаментальные параметры бытия, никоим образом от субъекта не зависящие. Если бы не было этих объективных свойств, то у субъекта существовала бы лазейка - опять употребим термин Бахтина - из обязательности предстоящего долженствующего действия. Действительно, субъект всегда с полным правом мог бы говорить себе: «Я сейчас выберу свое присутствие не в этом, а в другом месте, где от меня никто ничего потребовать не сможет», или «Если не сейчас, то потом я сделаю то, что надо, и ничего существенно плохого не случится». И эти отговорки на самом деле в жизни сплошь и рядом происходят. Правда, происходят только тогда, когда человеку просто не важен выбор того или иного действия, даже с его необратимостью. Например, вспоминая пословицу, в общем-то, не важно, «с какой ноги вставать». Но здесь субъект выходит из плана долженствования в иной план, с иными критериями в выборе действий. Однако что заставляет человека определять степень важности как предстоящего выбора так, и того хронотопа, в котором оказался субъект? Ответ на этот вопрос содержится в третьей пред-посылке долженствующих действий.

Итак, по нашему мнению, третьим необходимым пред-положением долженствующего действия является присутствие неподвластного человеку центра исхождения этих долженствующих требований. И, выражаясь юридическим языком, эта непреодолимая сила есть не просто исток обращения к субъекту, но и, что важнее, носитель неизбежных санкиий за недолжное поведение. Здесь - в неизбежности и в неподвластности человеку наступления наказания за ослушание - кончается человеческая свобода, и он оказывается в области абсолютной необходимости. Этот центр исхождения санкций и определяет для человека, диктует ему, какой хронотоп, с какой окружающей обстановкой - по Бахтину, событие-бытия - становится важным для него в своей уникальности и необратимости. Другой вопрос, кто или что за этим центром исхождения санкций стоит: чья-то воля - служителя закона, Бога, совести; или природная необходимость - объективные законы природы. На уровне долженствования для человека существенна только неизбежность наступления отрицательных последствий за неверный выбор предстоящего действия. Важно подчеркнуть, что абсолютность требо- 
вания, основывающаяся на абсолютно неизбежном применении санкций за его, требования, неисполнение, заставляет субъекта признать наличие абсолютно непроницаемой границы у области, на которую распространяется его, субъекта, активность.

Но как раз отсюда и проистекает неслучайность того или иного поступка человека, его обязательность. Мотив действий обретает здесь оправданность, обоснованную, объективную причинность.

И еще. Парадоксально, но единство личности и единство ее жизни, ее самотождественность в мире как раз гарантируется нахождением ее в плане долженствования. Будущая неотвратимость наказания за переступление через заповеди, законы морали, природы, государства - за «грехи» - в прошлой жизни личности цементирует тем самым единство этой прошлой жизни, делает последнюю цельной. Отдельные моменты жизни обретают единый центр в единстве ответственности. Но центр этого единства находится не в самой личности, а в том, перед кем или чем этой личности приходится отвечать.

Теперь, имея перед глазами вышеизложенные рассуждения в качестве фона, обратимся к тексту «К философии поступка» и попытаемся ответить на вопрос: можно ли найти в этой бахтинской работе три выделенных нами пред-посылки долженствующих действий - свободу субъекта, его уникальное и необратимое временно-пространственное положение и наличие независимого от субъекта центра исхождения санкций, накладываемых за недолжное поведение?

Итак, первый вопрос: признает ли Бахтин за субъектом свободу выбора, имеет ли субъект, с точки зрения Бахтина, так называемую свободу воли? Как бы мы ни штудировали текст «К философии поступка», мы не найдем прямого утверждения этой первой пред-посылки долженствования. Только в одном месте Бахтин, подвергая критике этические воззрения Канта, пишет: «...воля действительно творчески активна в поступке» $[1,31$; здесь и далее в цитатах курсив наш - A.K.]. Следовательно, если Бахтиным признается творчески активный характер воли, то тем более им предполагается активность воли в выборе чего-то уже имеющегося в наличии, в частности уже имеющиеся в наличии возможности тех или иных действий. Можно сказать, что новизна - как специфическая и главная сторона любого творчества - в осуществленном выборе состоит как раз в реализации именно этой конкретной возможности и в недопущении к реализации других возможностей. И вообще, целью этических изысканий Бахтина в его «К философии поступка» как раз является поиск причины, обоснования долженствующих действий - «поступков», а значит, возможность каких-либо uнblx действий - не-должных - безусловно, предполагается. Впрочем, это предположение нигде в тексте не вербализовано. 
Переходим ко второму пред-положению, основанию долженствующего действия - к уникальности, незаменимости и необратимости пространственно-временных «точек» жизни человека. Удивительно, но все свои интеллектуальные силы Бахтин бросает на описание именно этого момента. Складывается впечатление, что одним из замыслов этой работы был как раз показ со всевозможных углов зрения сознания субъектом уникальности себя и своего места в мире. Почему у Бахтина произошло такое своего рода зацикливание на этой уникальности, мы постараемся показать в заключительной части нашей работы. Теперь же настала пора обильного цитирования анализируемой нами работы. Это позволит, перемежая цитаты вопросами и сталкивая цитаты между собой, уяснить для себя понимание Бахтиным специфики уникальности долженствующего хронотопа, в его, Бахтина, терминологии - «единственности». Описывая переживания субъекта, осуществляющего поступок, Бахтин верно, на наш взгляд, отмечает чувство пространственной уникальности положения субъекта в мире и описывает это так: «Я занимаю в единственном бытии единственное, неповторимое, незаместимое и непроницаемое для другого место» [Указ. соч., 41]. И Бахтиным справедливо в этой единственности видится причинность долженствования: «долженствование обусловлено его (субъекта) единственным местом в данном контексте события» [Там же, 34]. Что касается временного аспекта свершающегося поступка, то, по Бахтину, субъекту необходимо помнить: его действие свершается «уже безысходно непоправимо и невозвратно», и это совпадает с нашей оценкой такого действия как действия необратимого.

Теперь зададимся вопросом: откуда берется, в чем источник, по Бахтину, этой уникальности и незаменимости каждой точки в ее пространственно-временных координатах? Напомним, что в нашем анализе долженствования данная уникальность конституциионо присуща миру - мир таков, и ничего с этим поделать нельзя. Субъекту, правда, и мы это тоже отмечали, не всегда важно и необходимо учитывать единственность себя и своего места в мире; к обязательности же этого учета в долженствовании принуждает субъекта сознание неотвратимости санкций за неисполнение долга.

Что же у Бахтина? У него источник уникальности, единственности, занимаемого субъектом места - в самом субъекте, в его утверждающей все и вся активности. А творит-утверждает субъект единственность места и времени - где и когда он находится - через утверждение своей единственности и своей причастности к бытию. Бахтин пишет: «Единую единственность этого мира... гарантирует действительности признание моей единственной причастности, моего не-алиби в нем» [Указ. 
соч., 53], и «утвердить факт своей единственной незаменимой причастности к бытию» - [значит] войти в событие бытия [Там же, 43].

Здесь мы не будем повторять, подкрепляя соответствующими ссылками на текст, то последовательное эмманационное развертывание творческого я субъекта, имеющее место быть в «К философии поступка». Тех, кому это интересно, мы отсылаем к одной из наших прошлых статей, а именно: к статье «От термина к онтологии: субъективная метафизика М. Бахтина» [2]. Здесь же нам важно подчеркнуть, что исток единственности и субъекта и окружающего субъект бытия - внутри самого субъекта. Это сам субъект, его воля, его творческая, ничем не обусловленная активность. В подтверждение нашей оценки приведем еще пару цитат: «Долженствование впервые возможно там, где есть признание факта бытия единственной личности изнутри ее» $[1,43]-$ и еще: «Этот факт моего не-алиби в бытии, лежащего в основе самого конкретного и единственного долженствования поступка, не узнается и не познается мною, а единственным образом признается и утверждается [мною]» [Там же, 41].

Хорошо, пусть исток утверждения единственности и уникальности места субъекта в бытии - в самом субъекте, а не в мире, не в законах и не в нормах, грозящих субъекту неотвратимыми санкциями за непослушание. Но, быть может, за самими долженствующими требованиями Бахтин признает статус независимости ни от какой утверждающей активности субъекта? Быть может, нормы и законы - та сила, субъекту никоим образом не подвластная? Поставив этот вопрос, мы тем самым переходим к поиску у Бахтина третьей, на наш взгляд, главной, предпосылки долженствующих актов.

Увы, ответ на этот только что поставленный вопрос - тоже отрицательный. Для Бахтина и норма - не норма, и закон - не закон; для него это все - ничто, если не утверждено его, субъекта, утверждающей активностью. Конечно, воля, по Бахтину, не творит сам закон - закон со стороны своей содержательности, но закон утверждается ею, в терминологии Бахтина - «признается». Он пишет: «По отношению к закону, взятому со стороны его смысловой значимости, активность поступка выражается только в действительном осуществляемом признании, в действительном утверждении» [Указ. соч., 31]. И Канта Бахтин критикует не со стороны объективной обязательности исполнения моральных законов, но с позиции субъективизма, индивидуализма. По Канту, с точки зрения Бахтина, «закон предписан себе самой волей, она сама автономно делает своим законом чистую законосообразность - это имманентный закон воли», и далее: «Воля-поступок создает закон, которому подчиняется, то есть, как индивидуальная умирает в своем продукте» [Там же, 30]. Бахтина не устраивает здесь не отсутствие у воли 
активности вообще - активности как трансцендентального атрибута сущности морального субъекта, но отсутствие у воли активности индивидуальной. По отношению к последней трансцендентальная, можно сказать, механически задающая самой себе моральный закон воля тоже ничто - и это справедливо! - и нуждается, по Бахтину, со стороны воли индивидуальной своего утверждения,.

В этой связи любопытна оценка рассуждения Бахтина С. Аверинцевым, представленная во втором примечании к работе «К философии поступка» [Там же, 323]. Все оценки последнего основаны, по всей видимости, на «средневековой концепции естественного закона как божьей скрижали в сердцах людей», т. е. на «метафизике естественного закона» [Там же], а значит, истинно моральный поступок, по С. Аверинцеву, естественно, должен свершаться на фоне «подлинно нравственного забвения о себе» [Там же]. Это мало чем отличается от кантовской всеобщности трансцендентальных законов морали, а следовательно, и к этому обоснованию можно отнести справедливую критику Бахтиным всяческого механицизма человеческих поступков как индивидуальныlx действий. И еще, верно оценивая фарисейство, «в силу которого человек, выбравший быть специально и прежде всего иного человеком этическим, - это не особенно хороший, не особенно добрый и привлекательный человек». С. Аверинцев, как мы уже отмечали, истинно нравственным считает действие, при котором субъект весь направлен на другого, на помощь ему, без отвлечения «эгоцентрическим самодовольством или столь же эгоцентрическим самоукорением» [Там же, 324]. Из этого следует, что добавь к фарисейству желание помощи другому, забывая при этом себя, и все будет в порядке - ты в плане долженствующей активности. Но помещение в поступающее сознание - в акте свободного выбора - ценностной доминанты другого еще не гарантирует предстоящему действию неслучайный, обязательный характер. С другой стороны, даже помня о себе - что это $m b l$ должен совершить долженствующее действие, что тебе приходиться это делать, что иначе будет плохо, - вполне можно остаться в сфере долга. Долженствованию необходимо, чтобы оно стало действительно долженствованием, скорее не «нечто из меня исходящее», по Бахтину, и не нечто самозабвенное, по Аверинцеву, но нечто из вне - не пространственно, а онтологически из вне - на меня направленное, меня предупреждающее и в этой своей активности от меня не зависимое. Статус же метафизичности этого нечто для моей долженствующей активности, в общем-то, не важен.

Но вернемся к тексту «К философии поступка». Что же пишет Бахтин о нормах? Быть может, в их описании мы найдем ту принуждающую к действию силу, что и делает последнее собственно долженствующим? В тексте находим: «Норма - специальная форма волеизъявле- 
ния одного по отношению к другим, и как таковая, существенно свойственная только праву (закон) и религии (заповеди), и здесь ее действительная обязательность - как норма - оценивается не стороны ее смыслового содержания, но со стороны действительной авторитетности ее источника» [Указ. соч., 29]. Выходит, что исток обязательности норм к исполнению - в авторитетности того, кто ее создал, или, используем модное слово, озвучил. Но чем обоснована эта авторитетность, Бахтин не говорит, словно авторитетность - не имеющая основание и причину первосущность. Он не видит, что авторитетность норм морали и религии, правовых законов государства основана на осознании субъектом того факта, что за нарушение их он может подвергнуться наказанию со стороны того, кто или что следит за исполнением этих законов и норм: угрызений совести, наказания Божьего, карательных органов государства.

И в других областях деятельности субъекта, где осуществляется его, субъекта, долженствующая активность, - в культуре и в мире природы - Бахтин ничем не обосновывает обязательности долженствующей активности. «Во всех остальных областях норма является словесной формой простой передачи условного приспособления неких теоретических положений к определенной цели: если ты хочешь или тебе нужно то-то и то-то, то в виду того, что...(теоретически значимое положение), ты должен поступить так-то и так-то» [Там же, с.29]. Что вынуждает субъекта, какая из сторон этих «теоретически значимых положений» поступать именно так, а не иначе Бахтин не говорит: должен - и все.

Итак, третьей необходимой пред-посылки для долженствующей активности субъекта - наличия источника обязательных, неотвратимых санкций, применяемых к субъекту за неисполнение предписания законов государства, морали, религии, природы - мы не находим у Бахтина. С чем же остается сознание субъекта? Только с первыми двумя предпосылками - со своей свободой и с осознанием уникальности, единственности себя самого и мира вокруг. Как, в каком качестве можно оценить действия при наличии в сознании этих двух факторов? Только в качестве действий, свободно выбранных и необратимо свершаемых. Необратимость действия означает, что какое бы действие субъект ни выбрал, вернуться во времени назад не получится: он сам и мир уже невозвратно изменились, исправить уже ничего нельзя. Конечно, как мы отмечали, хотя de jure любые действия необратимы, de facto эта необратимость не всегда нам важна, да и исправить что-то все-таки можно. Тем не менее, по Бахтину, субъект, постоянно держащий в уме это чувство единичности себя и мира, осознает любые свои поступки как необратимые и невозвратные.

Однако логический объем необратимых действий шире логического объема действий долженствующих - первый включает последний как 
свою часть - а значит, не все необратимые действия есть действия долженствующие. Что не хватает необратимости стать долженствованием? Просто необратимость не дает критерия в выборе действий, тем более не дает критерия, по которому эти действия становятся для субъекта обязательными. Пусть субъект знает, что любое его действие необратимо, но какое из всех возможных предстоящих действий, выбрать, причем выбрать действительно с чувством абсолютной обязательности, обоснованности и правильности? Но и после выбора, и после самого действия субъект не найдет оснований и объяснений самому себе, почему же он выбрал это, а не другое, и так ли обязательно для него это предпочтение в выборе.

Резюмируя, можно утверждать, что Бахтин феноменологически вскрыл не сознание с установкой на долженствующее действие, но только сознание при действиях необратимых. Он остановился на полдороги, не дойдя до истинных причин ответственного поступления.

Теперь, как мы и обещали, попытаемся ответить на вопросы: почему Бахтин именно так, а не иначе описал долженствование? почему он не дошел до всестороннего понимания причин долженствующей активности? в чем причина ущербности его концепции долга? Сразу оговоримся: мы будем искать эти причины исключительно в самих произведениях Бахтина, руководствуясь принципом, который он декларирует в работе «Автор и герой в эстетической деятельности» [4]: «...он [художник] весь в созданном продукте, и ему остается только указать нам на свое произведение; и действительно, мы только там и будем его искать» [Указ. соч., 92].

Причины этого находятся довольно легко, достаточно проанализировать то, от чего отталкивался Бахтин в своих построениях феноменологии поступка и какие задачи при этом ставил.

Что касается задач, то если обратиться к первой работе - «Искусство и ответственность», - которая была написана Бахтиным непосредственно перед тем, как он приступил к своей «К философии поступка», и которая явилась своего рода программным манифестом, декларацией философских намерений молодого Бахтина, то в ней мы читаем: «Искусство и жизнь не одно, но должны стать во мне единым, в единстве моей ответственности» $[2,8]$. Значит, главной тогдашней целью Бахтина было включение искусства и, шире, культуры вообще - в жизнь, обретение смысла культуры в контексте жизни. «К философии поступка» как раз и предстает перед нами попыткой реализации этой программы. И от чего отталкивался Бахтин, из чего исходил, мы то же находим в его первой работе: «За то, что я пережил и понял в искусстве, я должен отвечать своей жизнью» [Там же, 7]. То есть Бахтин попытался построить этику, исходя не из самой жизни, не в ней пытаясь найти, выде- 
лить общие элементы специфически долженствующей деятельности. Проблемы Бахтина - не в переживании жизни, но в переживании культуры, именно культуру он пытается дополнить чем-то взятым из жизни, чтобы культура стала более весомой, более нужной. Его не устраивает не жизнь с её безответственностью, а культурная деятельность, её улегченность, необязательность. Бахтин в философии поступка, метафорически говоря, предстает перед нами в образе человека, только что оторвавшего свой взгляд от письменного стола и силящегося понять, что же ему не хватает в его творчестве?

Интроспективный анализ показывает ему, что в мир культуры творец её продуктов - а значит, и сам Бахтин как философ - не входит. С некоторой долей обиды на это он пишет: «в нем (в теоретическом мире) я не нужен, в нем меня принципиально нет» $[1,17]$, «мир смыслового содержания бесконечен и себе довлеет, его в себе значимость делает меня не нужнылм, мой поступок для него случаен» [Там же, 43], и в эстетическом мире «живут другие, а не я... себя я не найду в нем», «[это] любовно созерцаемая прошлая жизнь других людей» [Там же, 24].

И вот так, продолжая осознавать свою ненужность, Бахтин пытается нащупывать то, через что возможно это объединение культуры и жизни, через что осуществим их взаимный переход: «путь от посылки к выводу совершается свято и безгрешно, ибо на этом пути меня самого нет, но куда включить этот процесс моего мышления» [Там же, 26]. Но этот порождающий произведение культурный акт еще протекает и в жизни, обладает историчностью, а значит, через него и через творца как его источник можно попробовать совершить это объединение. Тут Бахтину приходит на помощь известный античный образ двуликого Януса: «Акт нашей деятельности, нашего переживания, как двуликий Янус, глядит в разные стороны: в объективное единство культурной области и в неповторимую единственность переживаемой жизни» [Указ. соч., 12]. Значит и нам, пытаясь реконструировать последовательность рассуждений и выводов Бахтина, все ценностное внимание надо направить не на продукт культурного творчества, не на его результат, а на сам акт, его порождающий: «Акт - поступок эстетического видения возвышается над всяким бытием - его продуктом - и входит в иной мир» [Там же, 23]. Именно в самозабвении в актах творчества и видит Бахтин ту причину разорванности культуры и жизни. Тогда объединяющей основой, началом, акта как «двуликого Януса» может быть только принадлежность этого акта одному субъекту - $u$ творящему в сфере культуры, $u$ живущему в мире, находящемуся внутри бытия. Он пишет: «Итак, ни у теоретического познания, ни у эстетической интуиции нет подхода к единственному реальному событию бытия, ибо нет единства и взаимопроникания между смысловым содержанием - продуктом и актом - 
действительным историческим свершением вследствие принципиального отвлечения от себя как участника» [Там же, 24]. Как не вспомнить здесь С. Аверинцева в уже упоминавшемся нами примечании «К философии поступка» с его справедливой критикой фарисейства...

Посредник найден - это самосознающее я творца. Но в чем же проявляется улегченнность актов творчества? В их обратимости, и отсюда - в их необязательности и случайности: любую фразу можно написать так, а можно и по-другому, потом взять и заново все исправить и т. д. Но именно необратимость актов в бытии - первое, что видит человек от письменного стола и вспоминая свое функционирование в жизни в реальном бытии. Следовательно, это чувство необратимости и нужно попробовать перенести в культурное творчество из жизненных действий - поступков. Однако Бахтин не видит - ибо, по-видимому, очень очарован осознанием себя в качестве везде-действующего я, - что обретение необратимости недостаточно для обретения обязательности тех или иных действий, через которую только и можно переместиться субъекту в долженствующий план.

С другой стороны, раз осознав, что единство деятельности как «двуликого Януса» - в единстве самосознания субъекта, в единстве его я, Бахтин вынужден распространить это чувство в две стороны: и в культуру, и в жизнь. Следствием переноса чувства самосознания в эстетический план явилась работа «Проблема содержания, материала и формы в словесном художественном творчестве» [3], в которой этому чувству прямо приписывается статус эстетического: восприятие произведения именно как художественного есть восприятие в нем себя в качестве активно творящей личности. Там он пишет: «Эстетический объект - это творение, включающее в себя творца: в нем творец находит себя и напряженно чувствует свою творящую активность» [Указ. соч., 317]. И еще, характеризуя ритм, как одну из чисто эстетических форм, Бахтин указывает, что последний «есть единство возвращающейся $\kappa$ себе, нащупывающей себя активности» [Там же, 311]. Более подробно анализ этой работы представлен нами в другом месте [6].

В работе «К философии поступка» это самосознание проникает и в план жизни: «Я-для-себя - центр исхождения поступка и активности утверждения и признания всякой ценности... оперативной штаб главнокомандующего моим возможным и моим долженствованием в событии бытия» $[1,57]$. Все в мире и в культуре, по Бахтину, - ничто без утверждения этого субъектом. Не только культурные ценности ничего не значат, «пока я не утвердил своей единственной причастности этому бытию» [Там же, 47], но и в мире «пафос моего участного не-алиби в бытии, это есть ответственное расширение контекста действительно признанных ценностей с моего единственного места» [Там же, 49]. Пра- 
вильно отметив единственность, временно-пространственную необратимость места и любого действия субъекта в бытии, он и здесь, как мы уже указывали, источником этой уникальности называет самого себя: «Единую единственность этого мира... гарантирует действительности признание моей единственной причастности, моего не-алиби в нем» [Там же, 53], а «утвердить факт своей единственной незаменимой причастности бытию - [значит] войти в событие бытия» [Там же, 43].

Конечно, если уж фундаментальные законы мироздания, по Бахтину, - только возможность без их утверждения субъектом в статусе действительно существующих, то что́ говорить о нормах морали и законов общежития: «нет определенных в себе значимых нравственных норм, но есть нравственный субъект с определенной структурой» [Там же, 14], а «по отношению к закону... активность поступка выражается только в действительном осуществляемом признании, в действительном утверждении» [Там же, 31]. Хорошо еще, что ничего не говорится в тексте о нужде в утверждении человеком заповедей Божьих... Тем более безнадежно искать у Бахтина упоминание о неизбежности применения против субъекта санкций за нарушение долженствующих положений. Ведь в его мире активность - только у одного субъекта - у самого Бахтина. И мира, и других людей, в общем-то, нет как независимых, активностных сущностей: «Он [мир] находится мною, поскольку я исхожу из себя в моем поступке» [Указ. соч., 54], и «я единственный из себя исхожу, а всех других нахожу» [Там же, 66].

Вот с этим чувством всеутверждающего я, названным «эмоционально-волевым тоном», в котором, по Бахтину, мы обозначаем именно момент моей активности в переживании, переживание переживания как моего» [Там же, 38], Бахтин, как со своего рода Иисусовой молитвы «я должен иметь долженствование» [Там же, 42], - и стремится предать любому действию человека - действию и в культуре, и в мире статус долженствующего. «Я есмь действительный, незаменимый - $u$ потому [!] должен осуществить единственность» [Там же, 42] . Но почему должен, на каком основании, и почему так, а не иначе? Да очень просто: «поступок [сам] задает себе свою правду» [Там же, 32] - ни больше, ни меньше. В этом все дело: сам задам себе долг, сам его и осуществлю. Без комментариев....

В заключение подведем некоторые итоги. На наш взгляд, попытка Бахтина представить феноменологию поступка, то есть описания долженствующе поступающего сознания, в общем-то, не удалась. Причина неудачи - в неверном понимании самого долженствующего чувства и его истоков. Да иначе и не могло быть, поскольку, идя от культуры к жизни, связывая их через сознающие себя действующим и в культуре, и в жизни я субъекта - даже с осознанием этим я своей уникальности, 
единичности и необратимости своих действий в мире, - ничего, кроме ни на чем не основанных, хотя и необратимых, но все-таки случайных действий этого я, описать бы и не удалось. Перефразируя Бахтина, справедливо отмечающего, что у Канта «Этическое долженствование извне пристегивается» [Там же, 28], можно сказать, что у самого Бахтина долженствование пристегивается изнутри.

Уже в своем следующем тексте - «Автор и герой в эстетической деятельности» - Бахтин хотя и описывает действие субъекта в мире - в событии бытия, - но это описание есть феноменология просто осмысленных, то есть иелеполагающих действий, без ощущения необратимой уникальности. Значит, в этой работе Бахтин еще дальше уходит из долженствующего плана, из плоскости этически поступающего сознания. Его все больше увлекает мир художественного творчества, в котором я субъекта имеет больше оснований не забывать себя в качестве единственно творящей, единственно активной силы. Но здесь уже возникает другая проблема; а именно - как совместить чувство собственной активности, которое является основным в эстетически воспринимаемой форме художественного произведения [см. «Проблемы содержания, материалы и формы в словесном художественном творчестве»] с ощущением самодовления, цельности, а значит, самодостаточности тех же самых эстетических форм. Но это тема уже другого исследования...

$$
\text { Литер атура }
$$

1. М. М. Бахтин К философии поступка // М. М. Бахтин. Работы 20-х годов. Киев, 1994.

2. М. М. Бахтин Искусство и ответственность // М. М. Бахтин. Работы 20-х годов. Киев, 1994.

3. М. М. Бахтин Проблема содержания материала и формы в словесном художественном творчестве // М. М. Бахтин. Работы 20-х годов. Киев, 1994.

4. М. М. Бахтин Автор и герой в эстетической деятельности // М. М. Бахтин. Работы 20-х годов. Киев, 1994.

5. А. Кальсиин От термина к онтологии: субъективная метафизика М. Бахтина // Терминоведение. Москва, 1993, № 3 .

6. А. Калыгин Диалектичность эстетической деятельности // Русский филологический вестник. Том 81, № 1. Москва, 1996. 


\title{
ЛИНГВИСТИКА
}

\section{Русские предложные единицы (предлоги и их эквиваленты). Синонимия и антонимия}

\author{
(C) кандидат филологических наук Е. Н. Виноградова, \\ кандидат филологических наук В. Л. Чекалина, 2004
}

Как известно, функцию предлогов в языке могут выполнять не только слова данной части речи, но и другие образования, которые выполняют данную функцию лишь в определенных условиях и являются эквивалентами предлогов. Таким образом, предметом рассмотрения в данной статье являются не только предлоги, но и их эквиваленты.

В процессе работы над словарем предлогов и их эквивалентов [Всеволодова, Виноградова. Клобуков, Кукушкина, Поликарпов, Чекалина: в печати], выяснилось, что предлоги вступают друг и другом в различные парадигматические отношения, демонстрируя тем самым свою системность. Оказалось возможным (и функционально необходимым) выделить целый ряд таких парадигматических отношений. В атрибуции предлога, разработанной в ходе описания предлогов [Всеволодова, Клобуков, Кукушкина, Поликарпов: 2003], представлен целый ряд позиций, отражающих различные парадигматические отношения. Перечислим их.

a) Семантическая парадигма предлогов - ряд предложных единиц, образованных одной лексемой и объединенных системными связями. Например, без сопровождения кого - в сопровождении кого - с сопровождением кого - при сопровождении кого, в пределах чего - в предель чего - из пределов чего - вне пределов чего - за пределами чего и т. Д.

б) Текстовая парадигма предлогов - парадигма синтагматических вариантов (присоединяемых элементов). Например, в доме - в нем; но не: $\boldsymbol{6}$ среду - *в нее; в состоянии шока - в этом состоянии - * в состоянии него - *в нем; из соображений конспирации - из конспиративных соображсений; пройти мимо школь - пройти мимо. Эта парадигма теснейшим образом связана с функционированием предлога в тексте. Подробнее см. [Виноградова, Чекалина: в печати].

в) Синонимы: вблизи чего - вблизи от чего - вблизи к чему - близ чего - недалеко от чего - невдалеке от чего и т. п.

г) Антонимы: вблизи чего - вдали от чего - вдалеке от чего и пр. 
Отметим, что указанные ряды (кроме текстовой парадигмы) системно пересекаются. Однако все указанные парадигматические ряды построены на противопоставлении различных признаков и не сводимы одни к другим. Так, в семантическую парадигму входят и синонимы (за пределами чего вне пределов чего), и антонимы (за пределами чего - в пределах чего). Вместе с тем, наряду с антонимами и синонимами в семантическую парадигму входят также единицы, связанные другими отношениями (в пределах чего - в предель чего). С другой стороны, в антонимические и синонимические ряды входят единицы, не попадающие в семантическую парадигму (вблизи чего - недалеко от чего - невдалеке от чего).

В данной статье мы остановимся на двух последних типах парадигматических отношений, то есть на синонимах и антонимах. Мы рассматриваем эти отношения параллельно, так как синонимические и антонимические ряды построены во многом сходно. Так, и синонимы, и антонимы делятся на лексические и морфологические.

\section{1. С и н о н и м ы .}

Как известно, одно и то же значение может быть выражено целым рядом синонимических реализаций. Ср.: за пределами чего - вне пределов чего; севернее чего - к северу от чего - на севере от чего - на север от чего; с помощью чего - при помощи чего, недалеко от чего - близко к чему и т. д. Другими словами носителем значения является не один предлог, а синонимико-вариативный ряд, представленный как лексически, так и морфологически различными членами [Всеволодова (а): в печати].

Как уже упоминалось, мы делим синонимы на лексические и морфологические.

1.1. Под лексическими синонимами мы понимаем однокоренные слова, относящиеся к разным частям речи, или разнокорневые слова, объединенные общностью смысла, типа: адекватно чему - в соответствии с чем, вплотную с чем-рядом с чем, в непосредственной близости с чем и пр. Приведем примеры.

- $\quad$ аналогично чему - по аналогии с чем - подобно чему

Действовать закон, как предполагается, будет аналогично закону об обязательном автостраховании - чиновники выберут несколько страховых компаний, которые будут страховать жилье, и издадут распоряжение, согласно которому у тех, кто не застраховал свой дом, будут отключать свет, газ, телефон, воду и т. д. (www.public.ru ${ }^{1}$ ). - Значит ли это, что по аналогии с налоговой полищией будет создана и полиция

${ }^{1}$ Сайт www.public.ru представляет собой публичную Интернет библиотеку, основные фонды которой «составляют публикации российских периодических изданий с 1990 года по настоящее время. В библиотеке представлено около 1000 источников: центральные и региональные газеты и журналы». 
лингвистическая? (www.public.ru). - Юмор действует на мозг подобно героину (Интернет).

Лексические синонимы также можно разделить на две группы: однокорневые и разнокорневые.

1.1.1.Однокорневые предлоги, типа: аналогично чему - по аналогии с чем; соответственно чему - в соответствии с чем и т. д.

1.1.2.Разнокорневые предлоги, типа: близко к чему - недалеко от чего, в дополнение к чему - в пандан к чему, вопреки чему - в разрез $с$ чем - в противоречии с чем и т. д. Ср.:

- под руководством кого - под начальством кого - под началом кого - под предводительством кого

Аналитическая служба ВЦИОМа под руководством профессора Юрия Левады провела исследование, иель которого - выяснить природу страхов современного россиянина (www.public.ru). - ...nоддержку его кандидатуры осуществляет народно-патриотический союз «Родина» под предводительством Сергея Глазьева (www.public.ru). - В США разгорается новый скандал - влиятельный конгрессмен Гэри Кондит подозревается в причастности к исчезновению студентки Чандры Леви, которая проходила практику под началом конгрессмена. (www.public.ru). - Василий Шуйский выслал против Болотникова отряд под начальством Юрия Трубецкого, но последний. Встретясь под Кромами с Болотниковым, отступил (Интернет).

В то же время синонимами предлогов могут быть не только единицы других частей речи, а даже других уровней языка. Так, синонимами ${ }^{2}$ предлога без чего являются:

а) предикативная отрицательная конструкция: чайник без носика чайник, у которого нет носика; чай без сахара - чай, в который не положили сахар; Нам и без огня тепло - Нам тепло, хотя и нет огня.;

б) $c+$ причастие-ликвидатив +NT: чайник без носика - чайник $c$ отбитым носиком;

в) свободный от + Np: жизнь без проблем - жизнь, свободная от проблем

В некотором смысле здесь можно говорить о синтаксических синонимах. Представляется, что интересным направлением исследования здесь могло бы стать описание условий выбора в тексте тех или иных форм, или условий дополнительной дистрибуции синонимов.

Как известно, характерной чертой синонимических отношений является то, что одно и тоже слово в разных значениях может входить в разные синонимические ряды. Предложная синонимия не является исключением. Так, предлог вровень с кем/чем при выражении реляцион-

2 Употребление термина «синоним» здесь во многом условно. 
ных, интерперсональных отношений синонимичен предлогу наравне $\boldsymbol{c}$ кем/чем: "Независимая газета» традиционно выходит на уровень геополитики - по мнению издания, стоит говорить не о кинематографе, а «о серьезнейшей мировой победе всей странь - теперь на мировой арене мь окончательно встали вровень со всеми ведущими государствами» (www.public.ru) (= мы окончательно встали наравне со всеми ведущими государствами, но не * дущиих государств). Если же вровень с кем / чем выражает пространственные отношения, он синонимичен предлогу до чего: Заяи остался видимым снаружи, так как уровень почвы на огороженной территории был почти вровень с забором (Интернет) (=уровень почвы был почти до забора, но не *уровень почвы был наравне с забором).

1.2. Если под лексической синонимикой мы понимаем разные лексические единицы, выражающие на денотативном уровне один и тот же смысл, то морфологические ${ }^{3}$ синонимы представляют собой одну лексическую единицу, различающуюся морфологическими характеристиками. Например, в цвет чего - в цвет чему.

Наши наблюдения показали, что морфологические синонимы могут различаться по ряду признаков. Анализ языкового материала позволил выявить следующие дифференциальные признаки:

1. Категория числа:

- $\quad$ в ладах с кем-в ладус кем:

А кузнец, который был издавна не в ладах с ним, при нем ни за что не отважится идти к дочке, несмотря на свою силу (Гоголь); Стараюсь высыпаться, еще стремлюсь всегда быть в ладу с самой собой и близкими (из интервью с Ольгой Волковой, АиФ); Не в ладу с холодной волей// Опрокинутая кружка (Есенин);

- $\quad$ в поисках кого - в поиске кого:

Генезис этих форм принадлежит доистории и ее первобытной культуре: человечество, в поисках осмысления действительности, объясняло явления внешнего мира путем сопоставления своей жизни с жизнью природы; отсюда - одухотворение ее и анимизм (Фрейденберг); По сообщению департамента федеральной государственной службы занятости населения по Вологодской области, за 12 месяцев 2003 года в службу занятости в поиске работь обратилось почти 37,6 тыс. человек (Интернет);

- $\quad$ в деле чего - в делах чего:

Вы старше и опытнее меня, вы уже достаточно искусились в деле любви (Куприн); Одну партию возглавляла церковь, сама претендо-

\footnotetext{
${ }^{3}$ О морфологической синонимии см. также [Виноградова, Чекалина: 2004].
} 
вавшая на десятину и на верховный авторитет в делах управления (Л. Гумилев).

Сопоставление лексических синонимов (размерами сколько - величиной сколько) позволяет говорить о том, что далеко не все лексические синонимы обладают идентичным набором членов в морфологической парадигме. Ср. размерами сколько - размером сколько, но величиной сколько - *величинами сколько, весом сколько - *весами сколько. Исследование языкового материала показало, что набор семантических характеристик морфологических синонимов также часто не совпадает. Так, морфологические синонимы из глубины чего - из глубин чего выступают в разных типах семантических отношений. Предлог из глубины чего допускает и пространственное употребление и временное: Нужно представить себе ствол, тянушийся из глубины миллионолетий... (Знание - сила, 10/1); Я из глубины коляски, из-под полотняного крова, воссылал благодарственные моления небу, что не еду верхом. (И. Гончаров); тогда как его морфологический синоним употребляется только в пространственном значении: Вода из глубин Мертвого моря отличается самой высокой концентрацией минеральных вещееств $u$ солей. (Интернет).

2. Категория падежа (падеж управляемого существительного): в количестве скольких единиц-в количестве сколько единиц, , в цвет чему - в цвет чего, в ущцерб чему - в ущерб чего:

- $\quad$ в замену чего - в замену чему:

В замену политико-денежной иензуре введём политиконравственную иензуру. В замену экономической иензуре введём мировозренческую иензуру (Интернет); Оставшиеся участники группы Guns $n$ ' Roses ищут себе нового вокалиста в замену кинувщего группу Экселя Роуза (Интернет);

- $\quad$ в тон чему - в тон чего

Мочка носа крупная, в тон окраса пятен или пятнистая (Интернет); Окраска кузова - в тон интерьеру, т. е. тоже жёлтая или синяя (Интернет).

3. Падежная форма предлогообразующего существительного:

- $\quad$ в пандан чему - в пандане чему, в пандан к чему - в пандане к чему

В пандан к этому рисунку приложен другой (Чехов, МАС); Знать, кривая способна тоже, в пандан прямой, // озверевши от обуви, пробормотать "не треба". // От лица фотографию легче послать домой, // чем срисовывать ангела в профиль с неба (Бродский); Ночь $и$ туман была в пандане с фильмом про франиузскую начиональную библиотеку - "Вся память мира", которая организована так же, как кони- 
лагерь (Интернет); В пандан заявлениям чиновников загадочное движение "Русское возрождение" высказалось за смертную казнь (Интернет);

xод чего

в противоход к чему - в противоходе с чем - в противо-

За час до соревнования, когда все посты были уже расставлены, отправили нас через лес в противоход трассы на один из контрольных пунктов (Путь и водитель); В первом случае длинный диагональный пас Зеедорфа с левого фланга нашел Шеву и он точно пробил в противоход вратарю, скинув мяч себе грудью, а во втором украинский форвард воспользовался грамотной передачей Руя Кошты, оставшись один перед воротами Пелиццоли (Интернет); Часть пути оказалась в противоходе с маршрутом ралли (Интернет); С момента хватки фигурант начинает движение в противоходе к собаке или вращение на месте $u$ наносит ей три удара стеком по корпусу (Интернет);

- $\quad$ вперед кого - впереди кого

Ему, сукину сыну, на базу кизяк летом нарезать некогда, лень вперед него родилась, залипает ему, а того не разумеет, что будылья, ежели резать одни иляпки на подсолнухи, будут снег держать, промеж них ветер не разгуляется, снег не унесет в яры (Шолохов); Шрапнель разорвалась впереди паровоза и осветила весь состав (Платонов).

4. Наличие/отсутствие первообразного предлога (второго первообразного предлога) в конъюнкции с субстантивом:

- $\quad$ именем кто - по имени кто

По малу времени от сего шел на свои места отставной служивый, бомбардир, человек убогий, по имени Мартын Кораблев, тащчился на костылях после Севастопольской кампании: пухли и отнимались у него ноги (Шмелев); У нее была Египтянка именем Агарь (Интернет).

- $\quad$ левее чего - левее от чего

Вот зверь! - говорит Дмитрий Александрович не без восхищения, становится сзади и левее "петуха" и с полминутки присматривается $к$ пейзажу впереди по курсу с точки зрения рулевого, потом перенимает руль в свои руки (Конецкий); Тонкая пластиковая полоска, проходящая внутри банкноты вертикально намного левее от портрета, указывает номинал банкноты в 100 долларов (Интернет);

- на глазах кого - на глазах у кого

И на двадиать первой минуте решился тактично все-таки выяснить: почему тот обозвал его собакой на глазах всего экипажа и при исполнении им, капитаном Фомичевым, служебных обязанностей? (Конецкий); Если раньше мне было стылдн подбирать кочаны на глазах у прохожих, то после этих слов я покраснел до слез от стыла за себя (Паустовский);

- 
Человек не может без того, чтоб над кем-нибудь не командовать, это ему самая сладкая служба, и чем дольше он просидел под началом другого, тем больше старается потом наверстать свое (Распутин); Крузенштерн и Лисянский были под началом у Резанова и ревновали к нему (Интернет);

- $\quad$ при посредстве кого - посредством кого

Он вписывает в сад некое присутствие, которое делает его не просто копией природы, но и копией духа, неким "демоническим" местом встречи человека с природой, где природа при посредстве Гения преврашается в двойника человека (Ямпольский); Захар Павлович уважал уголь, фасонное железо - всякое спящее сырье и полуфабрикат, но действительно любил и чувствовал лишь готовое изделие, - то, во что превратилось посредством труда человека и что дальше продолжает жить самостоятельной жизнью (Платонов);

- $\quad$ в направлении чего - в направлении к чему

Дед Гришака пожевал блеклыми губами, вытер зеленую иветень усов и ткнул костылем в направлении дома (Шолохов); Когда огонь усиливался, они ложились, окапываясь, и опять бросками передвигались к новому рубежу; а левее, в направлении к монастырю, повстанческая пехота никак не могла подняться (Шолохов);

- $\quad$ аналогично чему - аналогично с чем

Первое аналогично отрицанию двумерным сущзеством физической реальности у явлений, пребывающих вне его плоскости (Успенский); Аналогично с остальными марками - сопоставляйте ивет мотора с заявленным продавиом годом (Интернет); Единственная общезначимая характеристика "иветного слуха" для ивето-тональных аналогий - это отличие по светлоте мажора от более "темного" минора, а для ивето-тембровых сопоставлений аналогично с более светльми иветами (белый, голубой, желтый и т. п.) ассочиируются инструменты более высокого регистра звучания, и наоборот (красный, фиолетовый, синий чаще всего связываются в сознании с низкозвучащими инструментами) (Галеев);

- $\quad$ в количестве скольких единиц- количеством сколько единиц

Мурманские вузы 14 марта будут соревноваться в количестве проголосовавших студентов (Интернет); Для тех, кто имеет или обслуживает домены количеством десять и более предусмотрена новая программа по комплексному обслуживанию доменов (Интернет);

- несообразно чему - несообразно с чем

А это уже признак крайнего бесстылства - не только поступать злонамеренно, но и сплетать нечто такое, что даже с общими понятиями несообразно (Златоуст); А практик, действуя несообразно 
особенностям и возможностям позиции, наверняка получит полновесный ноль в турнирной таблице (Интернет);

- $\quad$ в обществе кого - в обществе с кем

Но Персиикий уехал в прекрасном автомобиле к сияющчим далям, в обществе весельх друзей, а великий комбинатор остался на пыльной дороге с дураком-компаньоном (Ильф и Петров); Вас радует любая возможность побыть в обществе с друзьями (Интернет);

- $\quad$ в отношении кого - в отношении к кому

В отношении эпистемологического статуса этих структур исследователь разделяет позицию Рикера, считающего, что они представляют собой своего рода культурный осадок развития изивлизации и выступают в виде мыслительных форм, подверженных всем превратностям исторической изменчивости и являюшихся специифичными лишь для западной нарративной традиции (Ильин); В отношении к растительности они - боги урожая, боги хлеба и вина, боги еды (Фрейденберг); Я нахожусь в оппозиции к самому себе (Котюков);

- $\quad$ в оппозиции чему - в оппозиции к чему

Партия останется в оппозиции к сущзествующему режиму (Интернет); Народный рух Украинь будет находиться в оппозиции «партии власти» до тех пор, пока «не будет иметь больиинство в парламенте и своего президента» (Зеркало недели);

- $\quad$ из рук кого - из рук у кого

Ты яд прими из рук у мудреца - из рук глупияа не принимай (Интернет); Там он опять получит в дар из рук творияа эту Богом созданную белую прелесть (Пастернак);

- в память чего - в память о чем

Не думайте, что вы виноваты так, как вам сказала Ида, и это я прошу вас сделать в память обо мне (Лесков); В память нескольких недель, проведенных со мною на водах, - вспоминал М. И. Пущчин Пушкин написал стихи на виньетках из "Евгения Онегина" в бывщем у меня "Невском альманахе" (Благой); Был и я среди донцов, // Гнал и я османов шайку; // В память битвы и шатров // Я домой привез нагайку (Пушкин).

Отметим, что морфологическая синонимика характерна для целого ряда эквивалентов предлога по функции. Последние будут регулярно открывать позицию для количественно-именного сочетания как в $\mathrm{N}_{\text {им }}$, так и в $\mathrm{N}_{\text {вин. }}$ р размером(-ами) сколько единиц - размером(-ами) в сколько единии, протяженностью сколько единии - протяженностью в сколько единиц, радиусом сколько единиц - радиусом в сколько единии, на расстояние сколько единиц - на расстояние в сколько единии, объемом сколько единии - объемом в сколько единии, длиной сколько единии - длиной в сколько единии и др. 
5. Различные первообразные предлоги в составе вторичного предлога:

- $\quad$ в адрес кого - по адресу кого

На него написали несколько анонимных писем, с иифрами, датами, фамилиями, обвиняли в нарушениях финансовой дисциплины, самоуправстве, нехороших разговорах в адрес начальства (Гранин); Первые слова их трудно было понять, потому что в салонах закипела такая ругань по адресу Мольера, что вообще немыслимо было что-либо разобрать сразу (Булгаков);

\section{- $\quad$ в вопросах чего - по вопросам чего}

Можно поправить товарища Енукидзе, - примирительно сказал Киров, - указать на его некомпетентность в вопросах истории (Рыбаков); Это отношение определяет и отзыв Салтыкова-Щедрина о работах Безобразова по вопросам кредита и банковского дела, пользовавшихся большим вниманием и авторитетом у современников (Интернет);

- $\quad$ в опоре на что - при опоре на что - с опорой на что

Проект модернизации России может быть осуществлен при опоре на национальный правящий класс (Интернет); Чеченцы оказались y Кремля в заложниках, а правозащитники (и Запад, в опоре на который заключается сила правозащитников) сделали именно то, что опасно делать и в отношениях с обычными бандитами (Интернет); На протяжении всей деятельности РХДП придерживается правоцентристской ориентации с опорой на здоровый просвещенный патриотизм (Республика);

- в память о ком - на память о ком

Не думайте, что вы виноваты так, как вам сказала Ида, и это я прошу вас сделать в память обо мне (Лесков); На память о Пугачевой у меня осталось много водки (Собеседник);

- $\quad$ в направлении к чему - в направлении на что

Выстрель глухо захлопали где-то за станицей, около сосен, в направлении на Черную (Шолохов); Минут через десять, аккуратно $и$ чисто одетьй, в черной кепке, он обычной дорогой, ни от кого не таясь, шагал по улицам города в направлении к Центральным мастерским треста «Краснодонуголь» (Фадеев);

- близко к чему - близко от чего

Совсем близко к носу высились две высокие трубы, поставленные рядом, поперек палубы, украшенные завитуиками и похожие на чугунные столбы какой-нибудь монументальной ограды (Ильф и Петров); Одевиись, подошел он к зеркалу и чихнул опять так громко, что подомедиий в это время к окну индейский петух - окно же было очень близко от земли - заболтал ему что-то вдруг и весьма скоро на своем 
странном языке, вероятно "желаю здравствовать", на что Чичиков сказал ему дурака (Гоголь);

- $\quad$ в борьбе с кем - в борьбе против кого

Лефорт повторял, что прежде всего нужна осторожность в борьбе с Софьей (Толстой); Марфа Борецкая - "Марфа-посадница", глава реакционной "литовской" партии среди новгородского боярства, склонявшейся к союзу с Литвой в борьбе против объединительной политики Москвы (Интернет);

- $\quad$ при условии чего - с условием чего

Задача Лаборатории состоит в том, чтобы создать 'форму', которая эволюичиониовала бы самостоятельно, т. е. при условии помощи и поддержки, но своими собственными силами (Успенский); Доставка товара производится с условием оплаты «наличными курьеру» (Интернет);

- на пару с кем - в паре с кем

Мадлен Олбрайт пела любовные арии на пару с Примаковым (Интернет); Я совершил несколько боевых вылетов в паре с Покрышкинымм и провел четыре воздушных боя (Интернет);

- на повестке чего - в повестке чего

На повестке дня - персональные компьютеры для учителей (Интернет); Борьба с терроризмом займет центральное место в повестке дня саммита "восьмерки" (Интернет);

- при участии кого - с участием кого

В Москве при участии «Яблока» прошел митинг "Студенты за бесплатное образование» (Интернет); Начинается сбор вопросов на телемост с участием губернатора (Интернет);

- $\quad$ при учете чего - с учетом чего

При учете мест обнаружения предметов с данным сюжетом в Месопотамии оказалось, что, к сожалению, лииь немногие из них имеют изначально точные привязки, т. е. места, где они были первоначально помещень, фиксировань (Интернет); Китай должен осваивать новые виды страхования с учетом развития сельских районов (Интернет).

Как показал анализ языкового материала в составе вторичного предлога, происходит десемантизация первообразного предлога. Ср. близко к дому - близко от дома, при участии обцественности - без участия обцественности, в память о встрече - на память о встрече. Таким образом, мы можем говорить о явлении нейтрализации предложных единиц.

6. Возможность компаратива эксплицировать логическую пропозицию: больше скольких единиц - больше, чем сколько единии, ближе скольких единиц - ближе, чем сколько единиц, 
- более скольких единиц - более, чем сколько единич

В ходе операции "Вихрь-Антитеррор" сотрудники милицчии Дальнего Востока изъяли из незаконного оборота более 12 тысяч единич, боеприпасов (Интернет); Детские дома заменяют семью более чем 900 омским детям (Интернет); Более чем 300 caмblх влиятельных представителей сталелитейной промышленности мира соберутся 3-4 февраля 2004 г. в Москве (Интернет);

7. Употребление разных форм сравнительной степени:

- $\quad$ высотой более чего- высотой больше чего

Впечатляют заросли ядовитого аконита высотой более двух метров (Интернет); Первую гряду камней поперек реки обходим слева и выходим на цеентральный поток с мощуными стояками высотой больше метра и больиим количеством подводных камней и плит (Интернет).

Отметим, что все эти признаки могут сочетаться, образуя тем самым своеобразную парадигму предлога. Интересно, что некоторые сочетания системны. Так, 6 и 7 пункты регулярно выступают в различных сочетаниях при параметрических предлогах, типа: высотой, мощцостью, длиной и пр. Они образуют 4 различных сочетания, которые представлены в языке: диаметром более скольких единиц, диаметром более чем сколько единиц, диаметром больше скольких единиц, диаметром больше чем сколько единиц. Таким образом, для параметрических предлогов можно с большой долей вероятности прогнозировать как минимум восьмичленную морфологическую синонимическую парадигму.

Морфологические синонимические ряды внешне напоминающие семантическую парадигму отличаются от последней тем, что морфологические синонимы имеют одно значение (хотя бы одно общее) и разную морфологическую форму, а семантическая парадигма состоит из единиц, различающихся и по морфологической форме и по значению.

Как уже упоминалось, антонимы, представляют собой сходно организованное множество и обладают сходными характеристиками.

2. А н т о н и м Ы .

Как и в синонимических рядах, мы можем выделить лексические и морфологические антонимы.

2.1. Лексические антонимы: в осужндене кого - в оправдание кого, аналогично чему - в противоположность кому и т. д.

- $\quad$ в зашиму кого - против кого

«Кремлевский блок» приветствует победу здравого смысла над коммунистической пропагандой и проводит многочисленные аргументы в защиту принятого закона (www.public.ru). - Правда, «Газета» отмечает одну пикантную деталь новой акичи «Идуичих»- сайентологический центр абсолютно легально существует в городе с 1992 года, сле- 
довательно, «Идущчие вместе» выступают против официиальной общественной организации, склоняясь, таким образом, к традиционно сектантским методам борьбы (www.public.ru).

Как помним, лексические синонимы делились на две группы: однокорневые и разнокорневые. Что касается антонимов, в нашем материале не представлено однокорневых предлогов, являющихся антонимами. Таким образом, лексическая антонимия включает только разнокорневые слова: благодаря чему - вопреки чему, в центре внимания кого - на периферии внимания кого и др.

- $\quad$ во вред кому - на пользу кому

«Коммерсант» особо отмечает заявление Путина о том, что разведка не будет использовать полученную информацию во вред законопослушному бизнесу (www.public.ru). - Орган Министерства обороны к букету стереотипов, составленному из тезисов о безволии генеральской верхушки и враждебности к армии либеральной интеллигенции, прибавляет и «фирменное» оригинальное объяснение поражения русской армии - «иепь случайностей, обращавщих обстоятельства на пользу японuุaм» (www.public.ru).

- внутри чего - вне чего

«Независимая газета» солидарна с этим предположением - у России были причины устранения Яндарбиева, а скандал связан, скорее всего, со сложными взаимоотношениями внутри четырехугольника «Катар США - Россия - чеченские террористы» (www.public.ru). - Сторонники жестких мер предлагают немало различных проектов, которые, по их мнению, могут исправить ситуачию - вплоть до введения специальной должности - «inspector'a тогит» - для надзора за детьми вне икольы (www.public.ru).

Как и с синонимией, можно отметить, что антонимия также относится к уровню лексико-семантического варианта (ЛСВ) слова. Так предлогу без чего в различных значениях будут соответствовать различные антонимы.

- $\quad$ с чьего пассивного волеизъявления $(\mathrm{Np})$ : Ясно, что все это не могло быть писано без ведома и соизволения самих князей (Иловайский) /с ведома и соизволения князей.

- $\quad$ с кем / чем (Nт) Без труда / C трудом поднять итангу.

- в чем (Nп) Быть без иляпь / в шляпе;

- на чем (Nп) Ходить без костылей / на костылях; туфли без каблуков / на каблуках.

Приведем еще один пример. Предлогу в $+\mathrm{N}_{\text {в }}$ в пространственном значении антонимичен предлог из чего (в школу - из школь); однако во временном значении такой антонимии нет (в cyбботу - *uз cyбботы); что же касается характеризационного значения (отряд в сто человек), 
то предлог из чего является в данном значении синонимом, а не антонимом (отряд в сто человек-отряд из ста человек).

2.2. Морфологическое разнообразие предложных антонимов не столь богато, как у синонимов. Отметим лишь некоторые случаи.

а) наличие/отсутствие первообразного предлога: в сторону чего - в сторону от чего и др.

- в направлении чего - в направлении от чего

«Новые известия» подводят итог - только такие люди могут двигать Россию «в направлении демократии и правового государства» (www.public.ru). - Шов можно выполнить в направлении слева направо, если вышивать двумя руками, и в направлении от себя, если вышивать правой рукой, а левой держать пяльица (Интернет). Шерсть растет в направлении от морды (Интернет).

б) различные первообразные предлоги в составе вторичного предлога: без помощи кого - при помощц кого, без оглядки на кого - с оглядкой на кого, в рамки чего - из рамок чего, в рамках чего - вне рамок чего и т. д. ${ }^{4}$

- $\quad$ в ущерб чему - без ущерба чему

«Известия » полагают, что эта инициатива оправдана - «во всем мире люди выбирают безопасность в ущерб демократии», России приходится делать то же самой и это неизбежно (www.public.ru). - «Российская газета» пишет, что продажа намеченных предприятий позволит обеспечить макроэкономическую стабильность России без ущерба экономической безопасности (www.public.ru).

- вне зависимости от кого - в зависимости от кого

«Статья 64-я Трудового кодекса запрещзает дискриминаџию работника в зависимости от места жительства и регистраџии»-говорится 6 заключении Генпрокуратуры (www.public.ru). - Однако «Газета» напоминает, что российских деятелей культуры уже сгоняли в различные союзы, что привело только к делению искусства на «официальное» и «подпольное» - настоящее искусство будет востребовано всегда, вне зависимости от дотаций государства (www.public.ru).

Типы антонимических отношений, представленных в предлогах, заслуживают особого внимания. Здесь мы покажем лишь некоторые из них.

В рамках пространственных отношений возможна антонимия нескольких видов.

\footnotetext{
${ }^{4}$ Отметим здесь также случаи, когда предлог «сросся» с формой существительного: внутрь чего - изнутри чего. 
а) антонимия по признаку сопространственность / несопространственность $^{5}$ : из пределов чего - из-за пределов чего, в поле чего - вне поля чего и т. д.

- в пределы чего - за пределы чего

Въезд грузовиков в пределы третьего кольйа в Москве будет ограничен (Интернет). - Скандал вышел за пределы области после того, как в редакиии газеты «Комсомольская правда в Калининграде» был произведен обыск - изъяв компьютеры, милиционеры заодно заблокировали последуюшие выпуски газеты (www.public.ru).

- в пределах чего - за пределами чего

Народнье «Труд» и «Комсомолка», особо не вникая в детали, написали о том, что теперь любой житель России может легко и быстро перевести деньги - пока в пределах России, а позже - хоть в Японию (www.public.ru). - «Газета» приводит перечень «успешных ликвидаций, осуществленных за пределами СССР органами ВЧК-ОГПУ-НКВДМГБ-КГБ» (включая пресловутый ледоруб, которым убили Льва Троцкого) (www.public.ru).

б) антонимия по признаку «вектор движения»: в границы чего - из границ чего и т. д.

- в предель чего - из пределов чего

Тем не менее, руководство ГИБДД Москвы подхватило эту идею - уже с нового года инспектора собираются пускать в пределы Бульварного кольиа только «велосипеды, мотоцикль, общзественный транспорт $u$ миниавтомобили - «Оку» и ее зарубежные аналоги» (www.public.ru). Американский гражданин У Цзяньмин был выдворен из пределов Китая за шипонаж в пользу Тайваня (Интернет).

- за предель чего - из-за пределов чего

Пресса разделилась на два лагеря: «военные» пишут о «последней агонии боевиков», которые пытаются «вырваться из капкана», но будут непременно уничтожены; «гражданские» полагают, что этот рейд наглядно продемонстрировал, кто действительно контролирует Кавказ, и что чеченская война, которой вроде бы нет, на самом деле медленно, но верно распространяется за предель Чечни (www.public.ru). Постановление администрачии Брянской области от 29.12.1997 №496 «Об условиях и порядке получения юридическими лицами, осуществляюшими торговлю алкогольной продукцией, ввозимой из-за пределов области, статуса юридического лица, аккредитованного администраичией Брянской области» (Интернет).

Еще один тип антонимии можно охарактеризовать как наличие / от сутств ие: без связи с чем-в связи с чем и т. д.

${ }^{5}$ При описании семантики предлогов с пространственным значением мы опираемся на систему значений, предложенную в [Всеволодова, Владимирский, 1982]. 
- без оглядки на кого - с оглядкой на кого

Российские газеты с оглядкой на Запад уже не раз обращались к проблеме свободного пользования оружием в России (www.public.ru). США будут бомбить Ирак без оглядки на «живой щит» (Интернет).

- без поддержки кого -при поддержке кого (с поддержкой кого) Большая часть прессы полагает, что эта иничиатива обречена на провал - без поддержки центристов предложение не пройдет, а «единороссы еще не получали приказа на уничтожение правительства» (www.public.ru). - «Коммерсант» сообщает, что в результате масштабного обыска при поддержкке автоматчиков прокуроры «изъяли подборку газетных статей на тему взаимоотношений ЮКОСа и прокуратуры, пообедали в местной столовой», сообщив, что «в прокуратуре кормят и дешевле, и вкуснее» и удалились - такое ощущение, что силовикам просто делать нечего, $и$ они зашли пообеdamb(www.public.ru).

2.3. Отметим также в предлогах наличие особого случая антонимии - энантиосемии. «Особую, непродуктивную, разновидность антонимов образуют слова, совмещающие в себе противоположные значения: «одолжить» - 1)дать в долг и 2)взять в долг и т. д. Это явление называется внутрисловной антонимией, или энанти осемией» [ЛЭС, 36]. Приведем пример данного явления в предлогах. Предлог за спиной $\boldsymbol{y}$ кого имеет несколько значений (см. [Всеволодова: (в) в печати]), в том числе 2 антонимичных друг другу.

а) за спиной $\boldsymbol{y}$ кого = «втайне, скрытно от кого / чего»: Москва $u$ Крым сговорились за спиной у Киева? (Интернет);

б) за спиной у кого = «иметь чью-л. поддержку, помощь»: На приемах у чиновников всех уровней гораздо внимательнее выслушают человека, за спиной у которого стоит много людей (например, студентьл подают коллективную заявку с подписями) (Интернет).

Таким образом, антонимические отношения оказываются богаче синонимических по своим «семантическим» признакам. Как показано выше, антонимы строятся, реализуя различные типы отношений (сопространственность / несопространственность, вектор движения и пр.) В то же время синонимическая парадигма намного богаче морфологически, в ней представлено большее количество членов, различающихся морфологически (ср. 7 типов морфологических синонимов). Что касается лексической синонимии, она тоже открывает большее число позиций для заполнения потенциально возможными синонимами: здесь есть как разнокорневые, так и однокорневые синонимы. Лексические же антонимы могут быть только разнокорневыми. 
1. Виноградова Е.Н., Чекалина В.Л. К содержанию понятия «внутренняя парадигма» предлога // Материалы конференции «Грамматика славянского предлога» 28-30 октября 2003 (в печати)

2. Виноградова Е.Н., Чекалина В.Л. Морфологическая синонимика предлогов // Русский язык: исторические судьбы и современность. II Международный конгресс исследователей русского языка. Труды и материалы. М., 2004.

3. Всеволодова М.В. Проект «Славянские предлоги в синхронии и диахронии: морфология и синтаксис». Русский язык. // Материалы конференции «Грамматика славянского предлога» 28-30 октября 2003 (в печати) (а).

4. Всеволодова М.В. Грамматика русского предлога (первые результаты одного научного проекта) (в печати) (в).

5. Всеволодова М.В., Виноградова Е.Н., Клобуков Е.В., Кукушкина О.В., Поликарпов А.А., Чекалина В.Л. Материалы к словарю «Предлоги и слова предложного типа в русском языке. Реальное употребление. Функциональная грамматика». Выпуск 1: А-И (словарные статьи); К - Ю (неатрибутированный список).

6. Всеволодова М.В., Владимирский Е.Ю. Способы выражения пространственных отношений в современном русском языке. М., 1982.

7. Всеволодова М.В., Клобуков Е.В., Кукушкина О.В., Поликарпов А.А. К основам функционально-коммуникативной грамматики русского предлога // Вестник Московского Университета. Серия 9. Филология. 2003, № 2.

8. Лингвистический энциклопедический словарь. М., 1990. 


\title{
О терминах «категория состояния» и «предикативы». Предикативы как предикат для выражения эмоционального состояния/отношения
}

\author{
(C) И.А. Антонова, 2004
}

Как известно, к словам категории состояния (КС) относятся слова, реже формы слов разных частей речи, но не во всех своих лексических значениях, а в тех, которые закреплены за употреблением этих слов в функции сказуемого: моросит, холодает; весело, интересно, жарко; рад, должен. Замечания об особенностях значения некоторых слов и форм слов встречаются еще в «Русской грамматике по начертанию сокращенной грамматики, полнее изложенной» (1831) А.Х. Востокова, в «Исторической грамматике» Ф.И. Буслаева, в трудах А.А. Потебни, А.М. Пешковского, А.А. Шахматова и других грамматистов. Но никто из них не ставил разряд слов, объединенных значением нединамического состояния, в один ряд с другими частями речи (т. е. не выделял их в особую часть речи). Первым выделил группу слов (нельзя, можно, надо, nора, жаль и т. п.), «подведение которых под какую-либо категорию затруднительно», Л.В. Щерба в статье «О частях речи в русском языке» (1928). Он определил их так: «...это слова в соединении со связкой, не являющиеся, однако, ни полными прилагательными, ни именительным падежом существительного; они выражаются или неизменяемой формой, или формой существительного с предлогом, или формами с родовыми окончаниями - ... или формой творительного падежа существительных (теряющей тогда свое нормальное, т. е. инструментальное значение)». Эти слова лингвист объединил в одну группу с такими словами, формами слов и выражениями, как холодно, весело; готов, должен, рад, болен; быть наготове, замужем, без чувств и др., и назвал их «категорией состояния».

Категорию состояния как особую часть речи выделял В.В. Виноградов («Русский язык. Грамматическое учение о слове», 1946). Он убедительно доказывает, что есть такая часть речи - категория состояния (КС), к которой относятся слова (реже, формы слов) разных частей речи, причём не во всех своих лексических значениях, а только в тех из них, которые закреплены за употреблением этих слов в функции сказуемого. Это могут быть: 1) безличные глаголы 3 л. ед. ч.: cветает, смеркается; 2) наречные слова, которые имеют формы времени (для прошедшего и будущего времени аналитические - с помощью глаголасвязки быть): больно, досадно, стылдно, рад; 3) краткие формы имен 
прилагательных, которые, утратив склонение и укрепившись в позиции сказуемого, приобретают оттенок времени («они перестают быть названиями, а становятся предикативными характеристиками» [1: 321]: мал, велик, рад, должен, намерен, горазд, солон, здоров = мастер (устар.) и люб (народн.-поэтич.) и т. п.); 4) наречия (жаль, жалко, грустно, весело и т. д.), 5) существительные (грех, лень и др.), 6) слова надо, нужно и т. д. При этом слова КС выражают значения, не зависящие от действия каких-либо внешних сил или от людей, хотя причина может быть и указана: «И скучно, и грустно, и некому руку подать в минуту душевной невзгоды» (М. Лермонтов); «...удочку оправили, закинули и дали мне держать удилище, но мне сделалось так грустно, что я положил его $и$ стал просить отиа, чтобы он отправил меня с Евсеичем к матери (С.Т. Аксаков). Слова КС могут выражать: состояние природы - ветрено, жарко, солнечно; состояние среды - грязно, сыро, темно; физическое состояние живых существ - больно, дурно, приятно; эмоциональное состояние человека - весело, грустно, страшно; интеллектуальное состояние человека - интересно, ясно, понятно; оценку какого-либо состояния, положения - легко, рано, хорошо. В.В. Виноградов отмечает, что все эти слова объединяет одно свойство - в предложении они выступают в роли сказуемого, т. е. предиката, односоставного (безличного) предложения: На улице шумно; Мне грустно; На душе тоскливо. Он пишет, говоря о словах КС, что «...употребление их исключительно, или преимущественно в функции сказуемого» [1:319].

Частеречное значение за КС признается и в вузовском учебнике под ред. В.А. Белошапковой «Современный русский язык» [2]. Она, вслед за Л.В. Щербой и В.В. Виноградовым, считает, что слова КС составляют особую часть речи, отмечая при этом, что А.М. Пешковский не выделял эти слова в отдельную часть речи. В.А. Белошапкова пишет, что, в традиционном учении выделение частей речи - «результат ряда компромиссов между синтаксическим, семантическим и морфологическими принципами классификации словоформ» [2: 464]. При определении слов КС В.А. Белошапкова выдвигает следующий подход: «...принцип "синтаксическая функция" должен быть использован только при классификации неизменяемых слов. Поэтому к категории состояния могут быть отнесены лишь неизменяемые слова» [2: 593]. Тогда состав КС ограничивается двумя группами слов: 1) существительными оторвавшимися от парадигмы и изменившими свою родовую характеристику (пора, лень, грех, срам и др.) и 2) словами, способными выполнять только функцию сказуемого (нужно, можно, жаль). Вот к какому выводу, который разделяет и автор статьи, приходит В.А. Белошапкова: «Категорию состояния как часть речи составляют неизменяемые полнозначные слова, единственная синтаксическая функция которых - функ- 
ция сказуемого» [2: 594]. Таким образом, слова рад, должен не входят в категорию состояния как изменяемые. Автор отмечает, что в каждом конкретном случае необходимо определить синтаксическую функцию неизменяемого полнозначного слова: Мне весело (КС) // Он весело (наречие) пел. При этом некоторые слова категории состояния образуют степени сравнения: нужнее, необходимее, а некоторые - нет. В связи с этим автор пишет, что «степень сравнения категории состояния формирует новые лексемы, которые принадлежат категории состояния как ее семантический разряд» [2: 594]. Таким образом, В.А. Белошапкова сужает количество слов, которые входят в КС, по сути - это наречия и существительные, которые не изменяются, а в предложении выполняют функцию сказуемого.

Закрепленность за КС синтаксической функции сказуемого определила другое название - предикативы. Термин «предикативы» был введен чешскими лингвистами во 2-й пол. 20 в. и применялся к той группе слов, которая в русской грамматике получила название «категория состояния» [6: 368]. В 60-70-х гг. 20 в. термин «категория состояния» в грамматических трудах все чаще заменяется термином «предикативы». Хотя в «Русской грамматике» (1980), «Краткой русской грамматике» (1989) в качестве самостоятельной части речи этот термин не рассматривается. Предикативы в научной литературе называются по-разному: категория состояния, безлично-предикативные слова, предикативные наречия. Но значение у них одно - это слова, обозначающие нединамическое состояние, и, главное, выступающие только в функции главного члена сказуемого однокомпонентного (односоставного или безличного) предложения: В лесу было тихо; Детям весело; На душе было тоскливо. Основную массу предикативов составляют предикативные наречия (темно, тесно, плохо) и страдательные причастия на -но, -то (накурено, заперто). Из наречий к предикативам относят: 1) слова на -о, соотносительные по значению с качественными наречиями, обозначающими чувство, эмоциональное или физическое состояние: весело, грустно, радостно, скучно, смешно, тревожно; ветрено, тепло, холодно; больно, душно, плохо; 2) слова, не соотносительные с качественными наречиями, обозначающими внутреннее физическое или эмоциональное состояние: совестно, стылно, тошно [6: 368]. Предикативные наречия первой группы пополняются за счет наречий, заключающих в себе качественные значения (в т.ч. за счет индивидуальных авторских употреблений): «... Так было мне, мои друзья, и кюхельбекерно и тошно» (Пушкин); «В таниевальном зале пустом непесенно» (Рождественский).

Поскольку нашей задачей является выявление предикативов (предикативных наречий) как предикатов для выражения эмоционального состояния или отношения (Э С/O), то, переходя с уровня морфологии на 
уровень синтаксиса, рассмотрим типы предложений, в которых предикативные наречия выступают в роли сказуемого. Например, Т.П. Ломтев в своей последней работе «Предложение и его грамматические категории» [5], выпущенной уже его учеником, рассматривает категории предложения, не употребляя термин «предикатив», предлагает категорию активности и демиактивности (полуактивности) [5: 171], отмечая нединамический характер «дативных» предложений. Он анализирует соотношение номинативных и дативных предложений: $О н$ взгрустнул // Ему взгрустнулось; Он скучает // Ему скучно; Он веселится // Ему весело и др. В состав основной массы дативных предложений входят глаголы, но может быть и наречный компонент, пишет Т.П. Ломтев [5: 181184]: Ему не было грустно, он не волновался, он затих весь... (Тургенев); Федору Ивановичу не было скучно, хотя жизнь подчас тяжела становилась (Тургенев), Ему (Базарову) вдруг стало досадно на самого себя (Тургенев), Елене Станиславовне было очень его жалко (Ильф и Петров). Ученый рассматривает, к какому типу простых предложений можно отнести различные дативные предложения, и доказывает, что их можно распределить по трем типам: неопределенно-личные, обобщенно-личные, безличные. При этом дативные наречные предложения, передающие Э С/О, могут быть неопределенно-личными: Было весело; и определенно-личными: $B$ душе она упрекала себя за другое: ..., за то, что ей тогда было хорошо и радостно (Эренбург), Шалун уж заморозил пальчик: / Ему и больно и смешно, / А мать грозит ему в окно... (Пушкин). Исследователь отмечает, что многие наречные предложения не допускают дательный падеж имени: Было серо тускло, безотрадно... (Чехов), Кругом было темно, безлюдно, уныло ... (Л. Толстой); «они выражают отношения с неопределенным лицом» [5: 181]. Предложения такого типа традиционно считаются безличными, но «эти состояния являются осмысленными только в том случае, если в качестве исходных предикатных предметов ... предполагаются одушевленные предметы» [5: 183], ср. Камню холодно, весело и т. д.

$\mathrm{C}$ точки зрения значения, смысла рассматривают предикативы ученые, которые исследуют коммуникативную грамматику. Г.А. Золотова в книге «Коммуникативная грамматика русского языка» [4] использует термин «предикатив (категория состояния)», отмечая, что «при предикате - предикативе на - - субъект обычно выражается именем в дательном падеже» [4: 105], подтверждая мысль Т.П. Ломтева. «Большая часть «безличных» предложений сообщает о признаке лица, человека. Признак этот, психологический или физиологический, вне человека не существует: Саше не спится, но весело ей (Некрасов); Лицо у него было грустное, и ей стало жалко его (Ю. Казаков); Когда она ушла, он почувствовал, что ему стало тоскливо (В. Распутин)» [4: 122]. «Только 
морфологический предрассудок против неноминативного подлежащего мешает увидеть в этих предложениях ... субъект и предикат, или имя предикативного признака состояния и имя его носителя» [4: 122]. В предложениях Мне весело, Сестру знобит, Ему не спалось, Вам выходить «фиксированы формы того и другого компонента: личное имя субъекта в дательном или винительном падеже, в предикате - слова категории состояния на -о, глаголы состояния в третьем лице или среднем роде, а также инфинитив» [4: 123]. Инфинитивные предложения Г.А. Золотова выделяет в отдельный разряд. Она подчеркивает, что не следует объединять признаки определенно-личных, неопределенноличных, обобщенно-личных и «безличных» предложений. «Это признаки разных измерений: так называемая «безличность» может совмещаться с любым из трех видов личности. ...Объединяет их общее, инвариантное грамматическое значение - независимость предикативного признака от воли субъекта - его носителя... Инволюнтативными и будем называть предложения разных моделей, обнаруживающие этот признак» [4: 124]. Как и Т.П. Ломтев, Г.А. Золотова считает здесь решающим признак активности / неактивности субъекта. Исходя из единства морфологических, семантических и синтаксических признаков, Г.А. Золотова представляет классификацию моделей предложения и их типовые значения: 1) глагольные, 2) адъективные, 3) субстантивные, 4) наречные, 5) квантитативные [4: 105]. При этом глагольные предложения могут сообщать о состоянии лица (Гость скучает. Деду нездоровится), предмета (Снег тает), среды (На дворе морозит. За окном свеmaem), хотя главное их значение: действие лица или функционирование предметов. А наречные предложения сообщают о состоянии лица (Всем весело, Ей больно, Детям страшно) и среды (На дворе морозно, В доме спокойно), хотя они могут сообщать о разных признаках предмета (Яййа - всмятку). Таким образом, к основному блоку предложений с предикативными наречиями, выражающими Э С/O (дативные предложения), примыкают и безличные предложения, которые передают ЭС: Было грустно и в весеннем воздухе, и на потемневшем небе, и в вагоне (А. Чехов), часто такие предложения выступают как литературный прием для начала развития повествования или для финала: Скучно жить на этом свете, господа (Гоголь).

В книге «Теория функционально-коммуникативного синтаксиса» М.В. Всеволодова отмечает, что, основываясь на смысловой классификации, можно группировать средства всех уровней языка. Тогда «категория состояния», выделенная Л.В. Щербой, и модальные слова, выделенные В.В. Виноградовым, в отдельные части речи не выделяются» [3: 30]. Доказывая эту мысль, она, в частности, пишет, что «состояние может быть значением лексическим (Брат болеет; Она весела; Я сейчас 
очень злой; Ему жсрко, В доме тихо; Я меня горе, Я - в горе, В дометишина); лексико-грамматическим у словоформы слова, не имеющего лексического значения состояния (Руки - в язвах, Клуб - на ремонте; Дом разрушен, Комната убрана)» [3: 31-32]. «Состояние выражается разными частями речи: Мне стало тревожно, Я тревожусь, Я в тревоге» [3: 32]. Таким образом, М.В. Всеволодова рассматривает «категорию состояния» как разряд наречий - предикативные наречия», при этом «расширив по сравнению с традиционной формулировкой круг занимаемых наречием позиций» [3: 32]. В своей книге лингвист представляет следующие семантические разряды наречий: «1) наречия, выражающие модальные смыслы (два подкласса), 2) наречия с собственно модальным значением, 3) наречия, выражающие оценки, 4) наречия, называющие диктальные признаки» [3: 67-69]. В последний разряд входят уже известные нам классы наречий места, времени, причины, образа действия и состояния. В зависимости от употребления в предложении наречия входят в группировки со значением состояния (в лесу грустно) или образа действия (грустно сказал). Есть и другие классификации. Но нас интересуют наречия-предикативы, которые выражают эмоциональное состояние: И скучно, и грустно и некому руку подать / В минуту душевной невзгодbl... (М. Лермонтов). Грамматическая основа этих предложений состоит из одного главного члена - сказуемого, характеризующего состояние природы, состояние человека, или выражающего оценку. В отличие от наречий роль предикативов в предложении синтаксически независима и может сочетаться с глаголами быть, становиться, делаться или употребляться без них: Мне стало стыльн. Ему сделалось грустно. Как уже говорилось, состояние может быть выражено не только в положительной, но и в сравнительной степени: Eмy cmaновилось всё веселее. На основе вышеизложенного можно выделить предикативные наречия, передающие Э С/O, что будет темой нашего дальнейшего исследования.

$$
\text { Ли те ратур а }
$$

1. Виноградов В.В. Русский язык (Грамматическое учение о слове). Изд. 2-е. М.: «Высшая школа», 1972.

2. Белошапкова B.A. (Отв. ред.) Современный русский язык. М., 1997.

3. Всеволодова М.В. Теория функционально-коммуникативного синтаксиса. М.: Изд-во Московского университета, 2000.

4. Золотова Г.А., Онипенко Н.К., Сидорова М.Ю. Коммуникативная грамматика русского языка. М., 1998.

5. Ломтев Т.П. Предложение и его грамматические категории. М., 1972.

6. Русский язык. Энциклопедия. М., 1997. 


\title{
К проблеме категоризации английского личного имени
}

\author{
(C) кандидат филологических наук С.И. Гарагуля, 2004
}

Имя личное занимает определенное место в классе имен существительных. Как известно, все слова любого языка могут быть систематизированы согласно определенным принципам категоризации, которая представляет собой “в узком смысле подведение явления, объекта, процесса и т.п. под определенную рубрику опыта, категорию и признание его членом этой категории, но в более широком смысле категоризация это и процесс образования, а также выделения самих категорий, членения внешнего и внутреннего мира человека сообразно сущностным характеристикам его функционирования и бытия, упорядоченное представление разнообразных явлений через сведение их к меньшему числу разрядов или объединений и т.п., а также результат классификационной (таксономической) деятельности" (Кубрякова, 1996: 42). Принципами категоризации являются: 1) установление самого общего значения слова как представителя определенного лексико-грамматического класса; 2) его индивидуальное значение; 3)грамматико-морфологические категории; 4) деривационные лексико-морфологические модели (Alexandrova, Komova, 1998: 44). Согласно этим критериям выделяются определенные части речи как лексико-грамматические классы слов. Соответственно имя существительное как такой класс обладает общим классовым значением предметности, грамматико-морфологическими категориями числа и падежа (категория рода рассматривается как лексикограмматическая), своими деривационными моделями (суффиксы существительных.

В традиционных грамматиках имя личное представлено как подкласс имени существительного, относящийся к именам собственным. В соответствии с принципами категоризации, указанными выше, попытаемся сравнить имя существительное и имя личное. В понимании имени собственного и личного, в частности, существует много противоречивых моментов, и об этом свидетельствует отсутствие единства взглядов на эти языковые категории. Это, прежде всего, касается наличия/отсутствия у них лексического значения. Значение - это, по определению О.С. Ахмановой, “отображение предмета действительности (явления, отношения, качества, процесса) в сознании, становящееся фактом языка вследствие установления постоянной и неразрывной его связи с определенным звучанием, в котором оно реализуется; это отображение действительности входит в структуру слова (морфемы и т.п.) в качестве его внутренней стороны (содержания), по отношению к кото- 
рой звучание данной языковой единицы выступает как материальная оболочка, необходимая не только для выражения значения и сообщения его другим, но и для самого его возникновения, формирования, существования и развития" (Ахманова, 1969: 160 - 161). Мы придерживаемся точки зрения тех лингвистов, которые считают, что в системе языка имя личное лишено лексического значения в его традиционном понимании и его главной функцией является наименование предметов, т.е. номинация (Дж. Милл, А. Гардинер, Э. Пулграм, Д.К. Реформатский, Ф.Ф. Фортунатов и др.): оно не выражает понятия, так как не заключает в себе признаков предмета и не характеризуется свойством обобщения. Мы также исходили из того, что наиболее общим значением этого разряда данной части речи является то, что оно - имя собственное, в отличие от имени нарицательного. Как представитель класса существительных имя собственное имеет наиболее общее значение этого лексикограмматического класса как части речи. Как все другие существительные, имя собственное выполняет те же синтаксические функции, имеет свои деривационные модели, указание на род. В случае необходимости оно получает дополнительную детерминированность через артикль, прилагательное и т.п. Кроме того, личные имена могут обладать так называемым энциклопедическим (информативным) значением, которое возникает в речи при отнесении только к одному лицу-денотату и предполагает его локализацию во времени, пространстве и множестве социальных полей. Следовательно, можно сказать, что у личных имен отсутствует связь с сигнификатом, они имеют только своих референтов, т.е. можно сказать, что они обладают также референциальным значением. В этой связи все же следует отметить, что есть личные имена, которые обладают прозрачной структурой, например, пуританские - Beata (cчaстливая), Renovata (обновленная) и так далее, а также имена, образованные от апеллятивной лексики, имеющей абстрактное значение, - Норе $($ надежда), Faith (вера), Prudence и т.д. Все библейские имена также мотивированы: Benjamin (любимый сын), Samuel (имя ему Бог) и т.д. Вообще все личные имена мотивированы: вопрос только в том, воспринимаем мы их мотивированными или нет. Таким образом, у них есть свое значение, если оно соотносится со словами общего языка, т.е. нарицательными существительными (апеллятивами). Например, женское имя Gwendolen состоит из компонентов gwen (бельій, белокурый) и dolen (кольць, лук). Подобное рассмотрение имени дает возможность понять мотивированность его структуры и соответственно мотивированность его значения. Однако это значение (т.е. значение исходного нарицательного существительного) с годами утрачивается, оно как бы отчуждается от звукового комплекса имени. И мы уже не думаем о том человеке, который носит, к примеру, имя Charity, что он должен обязательно 
проявлять милосердие по отношению к другим, только потому, что его имя произошло от апеллятива милосердие. Поэтому правы те, кто придерживается той точки зрения, что личное имя не имеет значения: оно прямо не соотносится с апеллятивной лексикой, от которой имя произошло. С одной стороны, оно действительно не соотносится с ней, но в то же время ведь не случайно люди дают имена по спискам святых, ангелов, в честь кого-то и т.д. Поступая так, они в выбранное для ребенка имя закладывают некое психологическое содержание, свое знание о том, что означает такое имя или с кем оно ассоциируется. Следовательно, имя личное как историко-психологическая культурная категория реально существует и руководит нашим выбором имен. Хотя потом взятое имя, конечно же, не переносит на нового носителя грехи и достоинства, успехи и поражения его другого носителя. Несомненно, это будет совсем неверно и неестественно, если мы начнем воспринимать или рассматривать каждого человека по имени Clement как кроткого и мягкого человека (Clement - от лат. Clemens < clemens - кроткий, мягкий) или каждую Agnes как непорочную и целомудренную (Agnes - от лат. Agnes, Hagnes < древнегреч. hagne - чистый, непорочный). Это еще раз подтверждает высказанную выше мысль о том, что имена действительно отторгаются от своих значений - значений исходных существительных. Они могут, например, просто стать модными именами независимо от того, что они значили изначально. Итак, имя личное содержит в себе много компонентов: культурный, исторический, психологический и так далее, и какой-нибудь из них может наследоваться, повторяться, воспроизводиться. К примеру, в истории Англии было восемь королей по имени Henry. Следовательно, так нужно было, чтобы эта семейная линия продолжалась, и она действительно продолжалась. Таким образом, в это продолжение имени вкладывали важное содержание. Позднее эту идею наследования имени заменили на другую: известны короли по имени George, Edward и т.д. Подобная ситуация имела место во многих странах мира, а не только в Англии. Такая картина может наблюдаться и на уровне семьи, когда, например, имя передается от родителей, а потом, если случается что-то плохое носителем этого имени, им некоторое время никого не называют, пока не забудется то негативное, что было связано с его носителем; будут давать другие имена, чтобы возникла положительная ассоциация. Получается так, что личному имени сопутствует не какое-то значение, а именно содержание и дополнительные коннотации.

Что касается грамматико-морфологических особенностей личных имен, то среди них выделяют следующие: они употребляются в единственном числе, не имеют ограничивающих детерминаторов (this, a, some, each), имеют определенный характер и одного референта. Как только 
имя личное перестает служить средством обозначения одного референта, имеет место движение от имени единичного к носителю обобщенного характера. В этом случае у личных имен появляются новые грамматические показатели: употребление во множественном числе и сочетание с артиклем .

В деривационном плане у личных имен выделяют модели, которые схожи с моделями существительных, но которые не так продуктивны, как последние, и по количеству их меньше: -an, -ist, -ize, -ation, -dom и др.

Имя личное имеет полевую структуру, включающую ядро и периферию. К ядру относятся четко выделяющиеся наиболее часто присваиваемые личные имена - мужские и женские со своими грамматикоморфологическими особенностями. Ядро подкласса имен поддается воздействию разнообразных процессов - усечению, сокращению, переосмыслению и т.д. И то, что происходит в ядре, выводит на первый план наиболее динамические процессы, которые характерны для периферии, т.е. той сферы, которая открыта для пополнения имен. Такое пополнение идет именно по тем путям, которые намечаются, возникают и формируются в ядре. Ядро показывает способ возможного обогащения класса имен, происходящего на уровне периферии: сокращение имени, его сложение или какие-то другие деривационные процессы, переход одного подкласса в другой (переход имен личных/собственных в нарицательные, нейтрализация родовых различий, создание национальнопризнаваемых имен, различные случаи переноса - имя-метафора и т.д.). Статистику употребления ядра личных имен можно представить следующим образом.

В 1981 г. в Англии и Уэльсе наиболее популярными были следующие мужские имена: 1) Andrew, 2) David, 3) Daniel, 4) Christopher, 5) Stephen, 6) Matthew, 7) Paul, 8) James, 9) Mark, 10) Michael, 11) Adam, 12) Richard; а также женские: 1) Sarah, 2) Emma, 3) Claire, 4) Kelly, 5) Rebecca, 6) Gemma, 7) Rachel, 8) Lisa, 9) Victoria, 10) Laura, 11) Catherine, 12) Nicola. В этом же году популярные имена в США (белого населения) представлены следующим образом - мужские: 1) Michael, 2) Jason, 3) Matthew, 4) Christopher, 5) David, 6) Brian, 7) Robert, 8) Daniel, 9) Steven, 10) James, 11) Ryan, 12) Joseph; женские: 1) Jennifer, 2) Jessica, 3) Sarah, 4) Melissa, 5) Nicole, 6) Kristin, 7) Katherine, 8) Elizabeth, 9) Michelle, 10) Christina, 11) Amanda, 12) Amy (Dunkling, 1983, p. 44 - 51).

Из изложенного выше материала видно, что имя личное не существует изолированно, а является подклассом имени существительного, так как оно обладает основными лексическими, грамматическими и морфологическими характеристиками, присущими последнему, т.е. имени личному свойственны в определенной степени процессы, кото- 
рые распространяются на остальных представителей этого класса, и имя вовлекается во все эти процессы, как и другие существительные. Как такой подкласс имя личное представлено во всех традиционных грамматиках английского языка. Однако следует отметить, что ему уделяется незаслуженно малое внимание. Об этом свидетельствуют результаты анализа теоретических и практических грамматик, изданных как за рубежом, так и в России. В них в основном дается информация лишь об имени собственном как таковом и совсем немного об именах личных. Так, в грамматиках S. Greenbaum. "The Oxford English Grammar", 1996; R.Huddleston. "English Grammar: an Outline”, 1998 речь идет только об имени собственном, его отличии от имени нарицательного, но не дается никакой информации об имени личном. B грамматиках R. Quirk, S. Greenbaum.“A Grammar of Contemporary English”, 1980; G. Leech, J. Svartvik. "A Communicative Grammar of English", 1983 имя личное упоминается только в контексте его употребления с артиклем. В теоретических и практических грамматиках, изданных в нашей стране, ситуация примерно та же: главным образом отмечают, что имя личное вид имени собственного, выделяют случаи употребления с детерминаторами (М.Я. Блох. “Теоретическая грамматика”, 1994; Л.С. Бархударов, Д.А. Штелинг. "Грамматика английского языка", 1973; O.V. Alexandrova, T.A. Komova. "Modern English Grammar: Morphology and Syntax", 1998; E.M. Gordon, I.P. Krylova. "A Grammar of Present-Day English", 1980; В.Л. Каушанская и др. “Грамматика английского языка”, 1967). Вот и все, что мы можем узнать в грамматиках английского языка об имени личном.

Словари также фиксируют определенную сферу применения и восприятия имени личного. Поэтому представляется интересным рассмотреть, как его употребление с артиклем отражено в словарях. Для этой цели были изучены следующие издания, описывающие неопределенный и определенный артикли: Longman Dictionary of Contemporary English, 1987; A.S. Hornby. Oxford Advanced Learner's Dictionary of Current English, 1989; Collins Dictionary of the English Language, 1986. Анализ этого материала показал, что набор случаев применения артиклей с личными именами принципиально тот же самый, но все-таки есть и случаи варьирования. Так, данные словари следующим образом трактуют факты использования неопределенного артикля с именем: в словаpe "Лонгман" 1) один из членов семьи: She was a Jones (= one of the Jones family) (фамильное имя); 2) произведение литературы, искусства со ссылкой на имя автора: This painting is a Rembrandt; 3) человек, с которым кто-то имеет сходство: They say the young actress is a (new) Marilyn Monroe!; 4) какое-то неизвестное собеседникам лицо: There is a Mr.Tom Wilkins on the phone for you; в словаре А.С. Хорнби перечисле- 
ны те же случаи; в словаре “Коллинз” приводятся только два - третий и четвертый, а в словаре Уэбстера вообще ничего не говорится о таком употреблении неопределенного артикля. Что касается определенного артикля, то это представлено так: в словаре “Лонгман” - данное лицо является самым знаменитым, самым важным, лучшим и т.д.: You can't be the Paul McCartney!; словарь А.С. Хорнби дает ту же информацию; словарь "Коллинз" же отмечает: 1) лицо, имеющее титул: the Honourable Edward Brown; 2) имена, имеющие ограничивающее определение: written by the young Hardy.

Как видно из представленного материала, в своей дейктической функции артикль по-разному определяет имя. Но общим в этом случае является то, что если имя личное употребляется с артиклем, то оно приобретает какое-то новое качество. Его употребление без артикля означает просто имя. Таким образом, когда имя индивидуализировано, оно не имеет маркированности. Когда же имя выполняет функцию репрезентации, оно получает маркировку, и эта маркировка может быть самой разнообразной, т.е. имя принимает определенные дополнительные знаки, которые определяют его место, степень глубины психологического восприятия. И здесь уже имеет место момент восприятия имени в сообществе людей, т.е. то, что происходит с ним через определенные дополнительные признаки:

"A new Theresa will hardly have the opportunity of reforming a conventional life, any more than a new Antigone will spend her heroic piety in daring all for the sake of a brother's burial: the medium in which their ardent deeds took shape is for ever gone. But we insignificant people with our daily words and acts are preparing the lives of many Dorotheas, some of which may present a far sadder sacrifice than that of the Dorothea whose story we know" (Eliot, 1994: 60).

Данный материал дает возможность провести лексикографическое сравнение, а именно: в каком словаре какое место отводится имени личному в общей последовательности подачи фактов употребления артикля с существительными, тем самым показывая, для какого словаря какое восприятие имени оказывается более важным. Этот материал подается различно в словарных статьях: словари по-разному вводят такую последовательность соотношения артикля и имени существительного в общем и артикля и имени личного в частности. В словаре “Лонгман” случаи употребления неопределенного артикля с именем личным в словарной статье даются под вторым (с фамильным именем), девятым, десятым и одиннадцатым пунктами (из 12 случаев употребления неопределенного артикля вообще), в словаре А.С. Хорнби - под восьмым, девятым, десятым и одиннадцатым пунктами (из 11); в словаре “Коллинз" - под вторым и шестым (из 6); с определенным артиклем в 
словаре “Лонгман” - под шестым (из 12), в словаре А.С. Хорнби - под десятым (из 11), в словаре "Коллинз” - под пятым, шестым, десятым и тринадцатым (из 13).

Все это свидетельствует о том, что как в грамматиках, так и в словарях дается недостаточно информации по личным именам.

$$
\text { Литература }
$$

1. Ахманова О.А. Словарь лингвистических терминов. - М., 1969.

2. Кубрякова Е.С. Краткий словарь когнитивных терминов. - М., 1996.

3. Alexandrova O.V., Komova T.A. Modern English Grammar: Morphology and Syntax. - M., 1998.

4. Dunkling L.A. First Names First. - L., 1997.

5. Eliot G. Middlemarch. - Chicago, 1994. 


\title{
Отраслевая и языковая специфика терминов немецкого гражданского права
}

\author{
(C) кандидат филологических наук П.А. Дамаданова, 2004
}

Как известно, после рецепции (наследования) римского права, немецкое право создало национальные кодексы в виде норм абстрактного характера. Исследователи считают, что это в значительной степени обусловлено заимствованной из римского права «юриспруденцией понятия» (Begriffsjurisprudenz). Юриспруденция понятия исходит из посылки, что правопорядок состоит из закрытой системы норм [Немецкорусский юридический словарь, 2000].

Оперирование не конкретной ситуацией, а абстрактными понятиями, свойственное немецкой юридической практике, стремление к идеалам римского права нашли свое выражение в терминологии права. Так, в гражданском праве нигде не упоминается о домах, полях и лугах. Вместо них употребляется термин «Grundstück» (земельный участок). Соответственно, в правовом смысле не «собирают урожай», а говорят об «извлечении плодов и доходов» (Fruchtziehung), «возврат долга» заменяется на «удовлетворение кредитора» (Befriedigung des Gläubigers) или «погашение долгового обязательства» (das Schuldverhältnis erlöschen).

Абстрактность присуща подавляющему большинству терминов гражданского права. В первую очередь к ним относятся отглагольные имена существительные: Forderung - требование, Genehmigung - одобpeние, Anfechtung - оспаривание, Minderung - уценка. В частности, отглагольные термины - существительные с суффиксом -ung являются наиболее продуктивным способом номинации действия. В тексте Гражданского кодекса Германии можно обнаружить целые номинативные цепочки подобных терминов:

Die zur Begründung des Pfandrechtes erforderliche Einräumung und Ergreifung der Innehabung wird dadurch nicht ausgeschlossen, dass... (§1147 BGB);

Das Vormundschaftsgericht kann den Vormund und den Gegenvormund zur Befolgung seiner Anordnungen durch Festsetzung von Zwangsgeld anhalten (§ 1837 (3) 1, BGB).

Как известно, необходимость дефинирования является общетерминологическим требованием. Для терминов права это требование приобретает особый смысл, поскольку точное и ясное понимание термина достигается при максимально точной дефиниции. 
Дефиницию термина гражданского права можно рассматривать как своеобразное руководящее указание к использованию. Например,

Überfall (\$911 Buch 3, Sachenrecht) - Früchte, die von einem Baume oder einem Strauch auf ein Nachbargrundstück hinüberfallen, gelten als Früchte dieses Grundstücks. Diese Vorschrift findet keine Anwendung, wenn das Nachbargrundstück dem öffentlichen Gebrauch dient (Плоды, упавшие с дерева или куста на соседний земельный участок, считаются плодами с этого земельного участка. Это предписание неприменимо, если соседний земельный участок находится в общественном пользовании - 911 книга 3, Вещное право).

Говоря о специфике терминов гражданского права, хотелось бы отметить такое их свойство, как неопределенность объема и содержания, которое большинством исследователей воспринимается как самоочевидный факт (Г. Мюллер-Тохтерман, Э. Оксаар, Й. Эссер).

Терминами с неопределенным объемом содержания являются:

Ehrenbeleidigung - оскорбление чести

gute Sitten - добрые нравы

Mängelhaftung - ответственность за недостатки в исполнении принятого на себя обязательства

Treu und Glauben - добросовестность, доверие.

Е. Оксаар отмечает, что подобные термины не способствуют точности языка права, однако необходимы ему: «die unbestimmten», oder «die wertausfüllungsbedürftigen Begriffe» sind ein Mittel, das die Rechtsprache unexakt macht, das aber für sie notwendig ist» [Оксаар, 1988:147].

По справедливому замечанию некоторых исследователей, неопределенные понятия допустимы в гражданско-правовых делах, что, однако, не должно иметь места в праве уголовном. Действительно, в толковании юридического содержания таких понятий, как «жизнь» или «смерть», недопустима всякая неопределенность. Подобного рода понятия интерпретируются в соответствии с определенными правовыми обстоятельствами.

Как бы ни были различны взгляды исследователей, можно сказать одно: так называемые «смешанные модусы» суть объекты идеального континуума, что объясняет их взаимопроницаемость, а значит, и взаимообусловленность. Этим, скорее всего, объясняется сложность однозначного толкования таких понятий, как «достоинство», «честь», «оскорбление/унижение чести», «долг», «свобода».

Другой особенностью терминов гражданского права является номинализация, т.е. превращение развернутого синтаксического целого в единое именование. Словообразовательные процессы, базирующиеся на данном явлении, В.С. Кубрякова определяет как «дефиниционное сло- 
вообразование, или словообразование на синтаксической основе» [Кубрякова, 1981:26]. Это особенно характерно для немецкого языка, которому свойственно образование новых слов путем субстантивного основосложения. Например:

Geldsortenschuld - обязательство, подлежащее исполнению в определенных денежных знаках;

Verzugsschaden - возмещение убытков, вызванных просрочкой платежа.

Приведенные термины представляют собой информационные единицы, характеризующиеся максимальной конденсацией понятийного содержания. Как видно, в русском языке подобным терминам соответствуют полилексемные термины, что обусловлено спецификой данного национального языка.

Для немецкой терминологии гражданского права характерно следующее явление: некоторые термины, совпадающие по форме с общеупотребительными словами, очень часто непонятны простым гражданам, даже если они сопровождаются законодательной дефиницией. Например, einverständliche Scheidung - развод по обоюдному согласию сторон. Для осуществления адвокатом такого развода необходимо обязательное выполнение трех условий:

1) супруги прожили один год раздельно;

2) оба супруга хотят развестись;

3) оба супруга согласны с последствиями развода.

По свидетельству немецких юристов, простые граждане интерпретируют такой развод совершенно иначе: они понимают под ним полюбовное расставание, при котором не возникает никаких споров.

Рассмотрим термин Selbsthilfe. Общеупотребительное слово Selbsthilfe обозначает «самопомощь», например, «zur Selbshilfe greifen» - «не прибегать к чужой помощи», «in Selbsthilfe bauen» - «построить собственными силами» [Большой немецко-русский словарь, 2001]. Неправовым является выражение «Hilfe zu Selbsthilfe», содержание которого иллюстрирует следующий пример: одна из развитых стран мира поставляет в Африку зерно с тем, чтобы люди сами пекли хлеб.

В области гражданского права термин Selbsthilfe определяется как «самовольное обеспечение и удовлетворение требования» (еіgenmächtige Sicherung und Befriedigung eines Anspruchs). Например, Н. знает, что сосед украл из его сада поливальный шланг и хранит его в своем гараже. Н. идет ночью к гаражу соседа, вскрывает его и забирает свой шланг. Такое действие называется в сфере немецкого гражданского права «самопомощь». Следует отметить, что такое действие является неправомерным: Н. обязан написать заявление в полицию. 
Существование подобных терминов нередко приводит к непониманию между юристом и гражданином/адресатом правовых предписаний, обусловленному незнанием последним правовой действительности.

$$
\text { Ли те рат ур а }
$$

1. Кубрякова Е.С. Типы языковых значений. М., 1981.

2. Esser J. Einführung in die Grundbegriffe des Rechts. Wien, 1949.

3. Müller-Tochtermann H. Zur Struktur der deutschen Rechtssprache. In: Muttersprache. Jg. 1959. H. 69.

4. Oksaar E. Fachsprachliche Dimensionen.Tübingen, 1988.

5. Большой немецко-русский словарь. М., 2001

6. Немецко-русский юридический словарь. М., 2000.

7. Российская юридическая энциклопедия. М., 1999.

8. Юридический энциклопедический словарь. М., 1997.

9. Köst E. Juristisches Wörterbuch. Wiesbaden, 1951.

10. Bürgerliches Gesetzbuch (BGB). München, 2003. 


\title{
Семантические особенности существительного Geist в современном немецком языке
}

\author{
(с) И.Б. Жамбалова, 2004
}

В данной статье рассматриваются семантические особенности существительного Geist в современном немецком языке. Интерес к этому слову не случаен. Существительное Geist, всилу своей гибридной природы, представляет определенную трудность для полного осознания носителями другого языка. В рамках когнитивного подхода в данной работе наряду с традиционными методами семантического анализа использовался концептуальный анализ, который позволяет обнаружить стоящую за абстрактным именем сущность, которая образует семантическое содержание абстрактной лексики.

С развитием немецкого языка система лексико-семантических вариантов (ЛСВ) существительного Geist претерпела ряд изменений. Coпоставительный анализ словарных статей лексемы Geist в лексикографических источниках ${ }^{1}$ позволяет сделать вывод о том, что наблюдаются существенные противоречия в ее подаче. Связано это в первую очередь с эволюцией развития значения этого слова и его употреблением на современном этапе. Кроме того, расплывчатость границ между значениями и смешение значений и употреблений слова - одна из трудностей, с которыми сопряжено правильное толкование основного лексикосемантического варианта в структуре лексемы Geist. Возникающие на практике сложные проблемы связаны не только с определением основного варианта, но и с выделением того или иного количества производных вариантов, а также с установлением связи и последовательности вариантов лексической единицы. В результате анализа языкового материала мы выделили у многозначного слова Geist следующие лексикосемантические варианты:

\footnotetext{
${ }^{1}$ Большой немецко-русский словарь: в 3-х т. Под общ. рук. О.И. Москальской.-3-е изд., испр. и доп.- М., 1997; Немецко-русский словарь: Ок. 95000 слов. - М.: 1992; Das große Wörterbuch der deutschen Sprache. 10 Bd. 3 Afl.-Dudenverlag. Mahnheim,1999; Etymologisches Wörterbuch des Deutschen. Unter der Leitung von Wolfgang Pfeifer.-AkademieVerlag Berlin,1989; Kluge F. Etymologisches Wörterbuch der deutschen Sprache.-20 Afl.Berlin,1967; Langenscheidts Großwörterbuch. Deutsch als Fremdsprache: das neue einsprachige Wörterbuch für Deutschlernende.- Langenscheidt. Berlin und München, 1993; Paul H. Deutsches Wörterbuch.-9.Afl.- Max Niemeyer Verlag. Tübingen, 1992; Wörter und Wendungen. Herausgegeben von Erhard Agricola.- Leipzig, 1977; Wörterbuch der deutschen Gegenwartsprache. Herausgegeben von Ruth Klappenbach und Wolfgang Steinitz.-6 Bd.- Akademie Verlag.Berlin, 1977
} 
1. «дух, душа» как продукт высокоорганизованной материи, с помощью которого объясняется существование и состояние материального мира

2. нематериальное, сверхъестественное существо, которое может быть добрым или злым по отношению к человеку:
а) «дух, призрак, привидение»

б) Библ. Божественный дух

3. «умственные способности человека, ум, мысль, остроумие»

4. «мыслитель, деятель, человек» в свете его духовных, нравственных и интеллектуальных качеств

5. «дух, образ мыслей, внутреннее содержание», которые в большинстве случаев характеризуют какое-либо явление, движение или период времени

ЛСВ существительного Geist в таком порядке перечислены не случайно. В данном случае мы ориентировались на эволюцию развития этого существительного. Как известно, семантическое единство заключается, прежде всего, в определенной связи отдельных значений друг с другом и их закрепленности за одной и той же оболочкой. Как показал анализ, между лексико-семантическими вариантами многозначного слова Geist существуют отношения различного характера.

Добытые опытом поколений знания и представления о действительности отражаются в полном объеме только в линейном развертывании единиц языка, т.е. в их сочетаемости в речи. С одной стороны, многозначное слово обладает в каждом своем варианте разной употребительностью и разным объемом семантического содержания. Так, по каждому из своих вариантов лексема взаимодействует с другими словами, образует свои языковые связи, отличные от связей данной лексемы по другим ее вариантам. С другой стороны, из сочетаемости абстрактных имен можно извлечь то, что знает носитель языка об означаемых этих имен, но о знании чего он не догадывается. Предикативноатрибутивная сочетаемость абстрактного имени позволяет обнаружить интуитивные представления носителей языка, проявляющиеся в ассоциативных связях стоящего за именем явления с другими явлениями мира, что дает возможность извлечь образные элементы структуры концепта, среди которых большое место занимают «вещественные коннотации».

Лексема Geist в основном лексико-семантическом варианте “дух, душа" имеет следующую сочетаемость:

den Geist aufgeben, den Geist aushauchen, das Buch atmet den Geist der Vergangenheit; Geist und Körper, Geist und Materie, ein gesunder Geist in einem gesunden Körper, der Geist ist willig, aber das Fleisch ist schwach 
Geist прежде всего этимологически связано с образом и идеей дыхания, духа. Дух - это религиозно-мифологическое представление, возникшее на основе олицетворения жизненных процессов человеческого организма. Понятие духа, души как бессмертной нематериальной части человеческого существа сложилось у европейских народов под влиянием христианства. На картинах, изображающих смерть христианского мученика, мы видим душу, отлетающую с губ или поднимающуюся в небо при помощи ангелов ${ }^{2}$. Дыхание человека образно ассоциировалось с дуновением, ветром, вихрем, крылатостью ${ }^{3}$. Из приведенной сочетаемости видно, что Geist выдыхают, испускают, от него отказываются, лишаются, им дышат. Он здоров и послушен.

Производные варианты - «дух, призрак, привидение», «Божественный дух» сочетаются со следующими прилагательными и глаголами:

der böse Geist (der Geist der Finsternis), sein gutter (böser) Geist, ein verwunschener Geist; jmd. ist von allen guten Geistern verlassen, von bösen Geistern besessen sein; an Geister glauben, Geister beschwören, Geister rufen, Geister bannen, ausrtreiben; ein Geist erscheint jmdm, ein Geist geht um, ein Geist spukt, von Geistern verfolgt werden, die Stunde der Geister (nach Mitternacht); als Geist umgehen, wie ein Geist aussehen, wie ein Geist auftauchen; in jmds Geiste handeln; der Geist Gottes, der Heilige Geist, die Außgießung des Heiligen Geistes, jmdm. als Heiliger Geist erscheinen, jmdm. den Heiligen Geist schicken

Кроме духа умершего человека известны также мифические и религиозные представления о ряде других духов, призраков, нематериальных существ, которые могут быть злыми, добрыми, заколдованными, следовательно, могут как приносить пользу (ангелы-хранители), так и вредить человеку. Так, добрые духи могут покинуть человека, а злые наоборот вселиться. В них верят, их призывают, с тем чтобы их подчинить, изгоняют. Они появляются, водятся, преследуют. То есть перед нами предстает некое существо, которое своим существованием или появлением доставляет неприятности, и от которого лучше всего избавиться, за исключением добрых духов. По аналогии это слово употреблялось для обозначения тщедушной внешности человека из-за его худобы и бледности. В христианском представлении Geist - это также и Божественный и Святой дух, воздействующий на внутренний мир человека. Он появляется, его посылают, он изливает.

Производный вариант «умственные способности, ум, мысль, остроумие» имеет обширную сочетаемость и целый ряд интересных ассоциаций:

2 Маковский М.М. Сравнительный словарь мифологической символики в индоевропейских языках. - М., 1996

${ }^{3}$ Мифологический словарь.- М., 1991 
a) Geist - птица

der Geist schwingt sich empor, beflügelt den Geistes (высок.), der Höhenflug des menschlichen Geistes

В греческой мифологии понятие души непосредственно связывалось с греческим божеством Психеей - олицетворением души, дыхания. Психея представлялась и как летающая птица. Души умерших в Аиде изображаются летающими, они слетаются на кровь, порхают в виде теней и сновидений. Психея представлялась также и в виде орла, устремляющего ввысь свой полет ${ }^{4}$. Отсюда вероятно всего возникает ассоциация Geist с птицей, которая с помощью крыльев может высоко взлетать, возноситься к небу.

б) Geist - инструмент - машина

keinen (nicht viel, wenig) Geist haben, besitzen, jmdn an Geist übertagen, jmdn an Geist übertreffen, zeigen, das zeugt von (wenig) Geist, seinen Geist spielen lassen, ein Mann von / ohne Geist, ein Mann mit viel (wenig) Geist; jmds Geist ist gestört, den Geist strapazieren (umg.), Mangel an Geist, der Reichtum an Geist, seinen Geist anstrengen, den Geist sammeln, einen komplizierten Geist bekommen, bilden, jmds. Geist drillen;die Geister prallen / stoßen hart / scharf aufeinander; ein großer, kleiner, hoher, komplizierter, schöner, scharfer, geschliffener, starker, einfassender, schneller, rascher, langsamer, flacher Geist;

Ceist - это некий инструмент - машина из металла, который характеризуется следующими признаками: его можно иметь много или мало, им можно обладать, владеть, превосходить кого-л. в его наличии, его показывают, демонстрируют, подтверждают, им можно играть. Он может быть неисправным, изнашиваться, его может не хватать, быть в изобилии, на него можно воздействовать, прилагая силы, повысить его работоспособность, их коллекционируют, т. е. накапливают, можно получить, собрать, сверлить. Две или несколько машин могут столкнуться, наехать друг на друга. Качества этого инструмента описывает его сочетаемость с прилагательными. Ум как инструмент может быть большим - значительным по размерам, маленьким - небольшим по размеру, сильным - значительным по силе, красивым, доставляющим наслаждение взору приятным внешним видом, обрамленным в оправу, острым, шлифованным, плоским, быстрым, медленным. Не случайна, на наш взгляд, в данном случае коннотация металл - символа прочности и защиты, представление ума как сильного, а не слабого орудия.

в) Geist - благородный человек

ein edler, freier, souveräner, aufgeklärter, schöpferischer, schaffender, erfinderischer, grüblerischer, reger, schöner, raffinierter, überlegener, be-

\footnotetext{
4 Маковский М.М. Сравнительный словарь мифологической символики в индоевропейских языках. - М., 1996 
deutender, kühner, lebhafter, beweglicher, wacher, lebendiger, regsamer, rastloser, schlichter, prosaischer, inferiorer, misstrauischer, argwöhnischer Geist, Trägheit / Lebhaftigkeit des Geistes; den Geist befriedigen, beschäftigen, den beweglicheren Geist beherbergen, ausbilden, schulen, jmds Geist bewundern, den Geist locken, fremden Geist in sich einlassen, Ist im Palast der freie Geist gekerkert?, Vertrauen in den Geist / zu Geist; der Geist spürt, verfecht, triumphiert, vereint sich, greift $z u$, die Errungenschaften des menschlichen Geistes; den Geist lähmen, sein Geist war erblindet, den Geist durch Lesen ernähren; den Geist abmüden, seinen Geist abquälen; die erschlafften Geister wieder beleben, die erschlafften Geister wieder erfrischen

Geist ассоциируется с одушевленным существом. Это существо может быть благородным, высоконравственным, свободным, независимым, просвещенным, свободным от предрассудков, творческим, изобретательным, склонным к долгим размышлениям, выдающимся, проявляющим активность, смелым, отважным, деятельным, бодрым, живым, полным сил и жизненной энергии, неутомимым, прекрасным, рафинированным, в то же время банальным, простым (т.е. скромным), чужим, посторонним, неполноценным, ленивым. Это существо необходимо удовлетворять, давать ему работу, приют, восхищаться им, его развивают, обучают, совершенствуют, впускают, заманивают, затачивают в тюрьму, ему доверяют. Оно может чувствовать, ощущать, отстаивать, торжествовать, объединяться с кем-л., добиваться результатов, берется за что-л. Как любое живое существо в физическом плане оно слабое, поэтому его может разбить паралич, оно может ослепнуть, его можно утомить, измучить, вскормить, ослабевшего вернуть к жизни, подкреплять его силы.

г) Geist - местность

ein schöner,umfassender, enger, flacher, tiefer Geist; etw. um-, vernebelt jmds Geistes, sein Geist ist umnachtet; im Geist[e] bei jmdm sein, langsam im Geiste sein, im Geiste bei jmdm weilen; jmdm. auf den Geist gehen, in den Geist kommen, in den Geist eines Werkes eindringen; etw. im Geiste überblicken (überdenken), jmdn letw. im Geiste vor sich sehen, etw. nimmt in jmds. Geist Form, Gestalt an

Geist в немецком языке ассоциируется также с некоторой местностью, прекрасной, обширной, не просторной, плоской, глубокой, которую может окутать туман, где наступает ночь. Здесь находятся, пребывают, сюда приходят, идут, проникают. В этой местности можно обозревать, наблюдать, предметы или явления принимают форму, образ.

д) Geist - нить

imds Geist ist verwirrt / jmds Geist verwirrt sich, sein Geist ist überspannt von Aufmerksamkeit; 
Geist ассоциируется с нитью, которая может запутаться, и которую можно сильно натянуть, из-за чего она может прийти в негодность.

е) Geist - жидкость

ein sprühender Geist, den Geist versrühen, seinen Geist sprühen las-

sen

Еще одна ассоциация Geist - это ассоциация с жидкостью, которую разбрызгивают, распыляют.

Производный вариант «мыслитель, деятель, человек в свете его духовных, интеллектуальных и нравственных качеств» в большинстве случаев сочетается с прилагательными:

ein unruhiger, dienstbarer, guter, freundlicher, hilfreicher Geist; ein großer Geist, große Geister stört das nicht, führende Geister, kleine Geister; jmdn als feinen Geist bewundern; der Geist der stets verneint, man weiß, wes Geistes Kind er ist, der Streit der Geister

Так, в результате метонимического переноса Geist в сочетании с прилагательными употребляется, когда говорят о неспокойном, услужливом, угодливом, хорошем, приветливом, радушном, всегда готовому прийти на помощь человеке, о выдающемся деятеле, руководящих личностях, маленьких детях, о скептике, который все отрицает, восхищаются утонченным человеком.

Производный вариант «дух, образ мыслей, внутреннее содержание», которые в большинстве случаев характеризуют какое-либо явление, движение или период времени имеет следующую сочетаемость:

ein freier, revolutionärer, demokratischer, progressiver sportlicher, kühner, starker Geist; der Geist der Zeit, der Olympische Geist, der Geist der Armee, der Geist der Empörung, Freiheit, des Widerspruchs, der Geist des Revanschismus, im Geiste der Freundschaft und des gegenseitigen Verstehens (der Verständigung), im Geiste des Patriotismus erziehen; in der Klasse herrscht ein guter, schlechter, kameradschaftlicher Geist, an Geist und Buchstaben

Здесь следует отметить прагматическо-социальную акцентуализацию слова Geist в сочетании большей частью с прилагательными и существительными. Предполагается, что различным отклассифицированным социумом ситуациям соответствует свой особый склад ума-духа: свободный, революционный, демократический, прогрессивный, спортивный, смелый, отважный, сильный дух; дух времени, эпохи, олимпийский дух, дух армии, дух возмущения, свободы, противостояния, реваншизма, дружбы и взаимопонимания, патриотизма. В классе царит хороший, плохой, дружеский дух (руск. атмосфера).

Таким образом, множество коннотаций, сопровождающих существительное Geist позволяет нам увидеть в нем широкий спектр асcoциаций, трактующих его и как материальное, и как биологическое, и как 
социальное. В концепте немецкого Geist отразилось, с одной стороны, представление о нем как об одушевленном существе, что нашло отражение в персонифицированном облике благородного, созидающего человека со всеми присущими для творческой личности качествами и в образе высоко парящей птицы. В основе такого представления лежит, на наш взгляд, связь с этимологией слова и греческой мифологией. С другой стороны, Geist - это машина-инструмент, то есть орудие для производства каких-л. работ, помогающий человеку и определяющий через обладание этим инструментом его силу и слабость. По всей видимости, подобная ассоциация возникла в более поздний период с появлением нового значения. Однако важно отметить, что Geist, будучи и машиной, и одушевленным существом, и местом находится внутри человека. Человек является носителем его, оценивает его состояние, работает над его состоянием, нежели заставляет его служить определенным целям. Характеристики Geist определяют человека с точки зрения его качеств, но не с точки зрения его интеллектуальной силы. Это объясняется в большей мере тем, что Geist - гибрид интеллектуального и духовного. Необычайно важна также и прагматическо-социальная акцентуация слова Geist, позволяющая усмотреть в нем отражение идеи стремления к благу и установок на предельную социализацию понятия. 


\title{
Сложные слова с основой существительного Leben в современном немецком языке
}

\author{
(C) П.У. Магомедова, 2004
}

Словосложение является весьма продуктивным способом словообразования в современном немецком языке. Преимущественное тяготение к словосложению объясняется не только определенными общими структурными закономерностями немецкого языка, но и стремлением к сжатости изложения, тенденцией к номинализации. Следует отметить, что в качестве основного элемента сложных слов чаще всего выступают основы существительных. За счет субстантивного словосложения покрывается постоянно растущая потребность в назывании новых явлений и предметов реальной действительности.

Высокая активность словосложения как способа производства новых лексических единиц обусловлена способностью одной цельнооформленной единицы выражать сложные понятия. Таким образом, сложные слова представляют собой как бы реализованное стремление носителей языка, с одной стороны, к экономии языковых средств, а с другой стороны - к наиболее полной передаче дифференцирующих признаков новых понятий и реалий.

Широкая употребительность существительного Leben в современном немецком языке находит свое отражение и в функционировании основы -leben- в составе сложных слов. Столь большая активность рассматриваемой основы в составе сложных слов позволяет говорить о первостепенности и несомненной важности понимания жизни в ее связи с социальными, эмоциональными актами, а также с окружающим миром в сознании людей. Т.И. Вендина считает, что «словообразование открывает возможности для концептуальной интерпретации действительности. Оно позволяет понять, какие элементы внеязыковой действительности и как словообразовательно маркируются, почему они удерживаются сознанием, ибо уже сам выбор того или иного явления действительности в качестве объекта словообразовательной детерминации свидетельствует о его значимости для носителей языка» (Вендина 1998: 9).

Основа -leben- в составе сложных слов способна выступать как в качестве определяющего, так и определяемого компонента. Сложные слова с основой -leben- характеризуются определительной связью составляющих их компонентов.

Широкая употребительность существительного Leben в современном немецком языке находит свое отражение и в функционировании основы -leben- в составе сложных слов. Столь большая активность рас- 
сматриваемой основы в составе сложных слов позволяет говорить о первостепенности и несомненной важности понимания жизни в ее связи с социальными, эмоциональными актами, а также с окружающим миром в сознании людей.

Т.И. Вендина считает, что «словообразование открывает возможности для концептуальной интерпретации действительности. Оно позволяет понять, какие элементы внеязыковой действительности и как словообразовательно маркируются, почему они удерживаются сознанием, ибо уже сам выбор того или иного явления действительности в качестве объекта словообразовательной детерминации свидетельствует о его значимости для носителей языка» (Вендина, 1998: 9).

Основа -leben- в составе сложных слов способна выступать как в качестве определяющего, так и определяемого компонента. Сложные слова с основой -leben- характеризуются определительной связью составляющих их компонентов.

Основа существительного Leben в качестве определяющего компонента сочетается с основами существительных и прилагательных, которые можно разбить на несколько групп согласно их семантическим признакам.

Первую группу образуют сложные слова, в которых определяемый компонент обозначает временные характеристики. Подобные сложные слова чаще всего представляют двухкомпонентные образования. Так, например, Lebenshälfte «половина жизни», Lebensalter «возраст», Lebenserwartung «вероятная (ожидаемая) продолжительность жизни».

Вторую группу представляют сложные слова, в которых определяемая основа представлена существительными, выражающими психологические характеристики. Данная группа в свою очередь делится на подгруппы, где вторая основа имеет а) эмоциональные и б) интеллектуальные характеристики. Так, например, Lebenslust «жизнерадостность, радость жизни», Lebensgenuss «наслаждение жизнью», Lebensklugheit «жизненный опыт», Lebenserfahrungen «жизненный опыт».

Третья группа представлена сложными словами, в которых определяемая основа выражает социальные характеристики. Например, Lebensrisiken «расходы на жизнь», Lebensunterhalt «средства к жизни», Lebensqualität «качество жизни», Lebensbereich «сфера, область жизни».

Имеются также трех- и более компонентные образования. Так, например, сложное слово Lebensarbeitsplatz «рабочее место». Определяющий компонент данного сложного слова, который в свою очередь представляет сложную основу -lebensarbeit- реализует значение «работа». Сложное же слово Lebensarbeit обозначает как работу вообще, так и результат работы всей жизни, дело всей жизни. 
Следующая, четвертая группа представлена словами со сложной основой -lebensmittel- в качестве определяющего компонента. Сложное существительное Lebensmittel имеет значение «средства для жизни, продукты питания». Основа -lebensmittel- в составе сложных слов реализует значение «продовольственный, пищевой», например: Lebensmittelgeschäft «продовольственный магазин», Lebensmittelhandel «торговля продовольственными товарами», Lebensmittelindustrie «пищевая промышленность», Lebensmittelkarte «продовольственная карта», Lebensmittelkaufhaus «продовольственный универсальный магазин”, Lebensmittelgesetz «закон об ответственности за продажу недоброкачественных продуктов». Сложные слова с основой -lebensmittel- характеризуются предсказуемой семантической структурой.

На данных примерах мы можем наблюдать преимущество сложных слов, заключающееся в их экономной и одновременно емкой структуре, что позволяет создавать краткие по форме и объемные по содержанию номинации.

В число сложных существительных с основой -leben- в качестве первого компонента входят существительные, представляющие собой образную характеристику обозначаемого явления, четко ощущается переосмысление второго компонента, при этом переосмысление носит метафорический характер, например: Lebensader «жизненная артерия», Lebensfaden «нить жизни», Lebensglut «пламя жизни», Lebenslicht «свет жизни (жизнь)», Lebensnerv «жизненный нерв», Lebenspfad «жизненный путь», Lebensschule «школа жизни», Lebensmühle «мельница жизни».

Сложные слова с образным переосмыслением обладают особой стилистической окраской. Они распространены как в художественной литературе, так и в публицистике.

В качестве определяемого компонента сложного слова основа -leben- сочетается с основами существительных субъектного характера. В данной модели определяющий компонент, представленный одушевленным предметом, указывает на социальный статус. Первый компонент выражает конкретный признак определяемого компонента, в то время как последний может обозначать как качество, образ жизни, так и жизнь вообще, например: Abenteurer-, Eremiten-, Künstler-, Artisten-, Bürger-, Einsiedler-, Faulenzer-, Musikerleben и т. д.

Первым компонентом сложных слов могут выступать также основы существительных, обозначающих растения и животных, например: Drohnen-, Hunde-, Pflanzen-, Sau-, Tierleben.

Значительно реже встречаются сложные слова, образованные по модели Adj+N. Например: Doppel-, Eigen-, Einzel-, Innen-, Privat-, Zivil-, Wohlleben. 
Продуктивной является модель $\mathrm{N}+\mathrm{Adj}$. Прилагательные, представляющие основы прилагательных в таких сложных словах, выражают отношение к жизни, например: lebensfremd, lebensfroh, lebensfähig, lebensecht, lebensgiereg, lebeshungrieg, lebensklug, lebenskräftig, lebensfeindlich, lebenslustig, lebensmüde.

В сложных словах модели $\mathrm{N}+\mathrm{N}$, где первый компонент указывает на ту или иную область социального происхождения, второй компонент -leben- реализует производное значение существительного Leben «совокупность общественных форм жизни», например: Berufs-, Geschäfs-, Konzert-, Kultur-, Sport-, Staats-, Theater-, Partei-, Rechts-, Verbands-, Vereinsleben.

Были выявлены следующие типы структурных моделей сложных слов с основой -leben-: N + N, Adj. + N, N + Adj. Наиболее продуктивной является структурная модель $\mathrm{N}+\mathrm{N}$. Из числа проанализированных сложных слов 400 представлено словообразовательной моделью $\mathrm{N}+\mathrm{N}$. Количество сложных слов, образованных по модели $\mathrm{N}+\mathrm{Adj}$, составило 36 единиц. Сложных существительных модели $\mathrm{Adj}+\mathrm{N}$ обнаружено в количестве 18 единиц.

Основа -leben- в составе сложных слов чаще всего реализует значение «образ жизни» существительного Leben. Значение «жизнь» peaлизуется в субстантивной модели, в которой основа -leben- является определяющим компонентом, а определяемый компонент характеризует долготу/краткость, опасность, смысл жизни.

Сложные слова с основой -leben- широко употребительны как в научно-публицистической, так и в художественной литературе.

$$
\text { Литература }
$$

1. Вендина Т.И. Русская языковая картина мира сквозь призму словообразования. М., 1998.

2. Левковская К. А. Именное словообразование в современной немецкой общественнополитической терминологии. М., 1960.

3. Левковская К. А. Теория слова. М., 1962.

4. Смирницкий А.И. Лексикология английского языка. М., 1998.

5. Степанова М.Д. Словообразование современного немецкого языка. М., 1953.

6. Степанова М.Д., Фляйшер В. Теоретические основы словообразования в немецком языке. М., 1984. 


\section{ЛИНГВОПОЭТИКА}

\section{«Жизнь и смерть в текстах Андрея Платонова» («Котлован», «Сокровенный человек», «Усомнившийся Макар», «Дневник»). Работа по восприятию текста с использованием приема «смысловой ход конем»}

\author{
(C) T.Ю. Tоропова, 2004
}

Кто сейчас расчленит этот сложный язык и простой, Этот сложенный вдвое и втрое, на винт теоремь Намотавшийся смысл. Всей длиной, иириной, высотой Этот встроенный в ум и устроенный ужас системы. Александр Еременко.

Любая система, как общественная, так и языковая, предполагает следование законам, предсказуемость. То, что является благом для диктатора и для ритора, становится пленом для писателя. Спасение от общественной системы - это всегда «тщщетная попытка». Возможно, отчасти и поэтому «жизнь», по мнению Андрея Платонова, - это «уnycкаемая и упущенная возможность».

Что же касается системы языка, то «спасение утопающих - дело рук самих утопающих». Андрей Платонов спасает себя как писателя, «утопая» в системе языка, т. е. он осваивает не только ее поверхность, но и глубину. В результате чего у читателя появляется шанс обнаружить несметные богатства открытий сокровенного. Для Андрея Платонова отсутствие чего-то «нечаянного в душе» - признак старости. Что-то «нечаянное», неожиданное, способное удивить, остановить внимание читателя, должно быть и в тексте. Внимание читателя останавливается на очевидном нарушении системы языка, которое оказывается объяснимым с помощью прохождения глубинных узуальных ходов речемыслительной деятельности.

Читатель сталкивается с необходимостью провести работу по восприятию текста. «Устроенность системы», ее «встроенность в ум» не только писателя, но и читателя в данном случае крепко помогает, и возникает «эффект сопричастности формированию и оформлению текста», а самостоятельно добытые смыслы дороже, с ними труднее не согласиться. Кроме того, восприятие текста не только линейно (по синтагме), но и в глубину (по парадигме) позволяет добыть больше смысла («густой язык А. Платонова»). Попытки подобрать поверхностно узу156 
альные синонимичные выражения оказываются тщетными, т. к. поверхностно узуальная фраза не так экономна (не говоря уже о метафоричности) и проигрывает в точности выражения замысла. Самое удивительное в этом, что проделанная работа по восприятию текста настолько превращает читателя в соавтора, что о точности выражения судит... читатель. Проводя работу по восприятию текста, можно воспользоваться приемом «смысловой ход конем». Его суть можно показать на примере анализа высказывания, объясняющего отношение к жизни многих персонажей Андрея Платонова. "Жить некуда, вот и думаешь в голову». Здесь два смысловых хода конем (см. сх. 1).

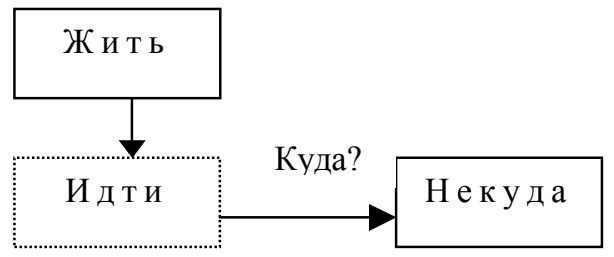

Схема 1. Первый ход.

Ассоциирование по парадигме (см. сх. 2):

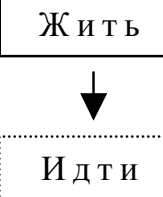

Схема 2.

- основанное на известной метафоре «жизнь - дорога» (“Via est vita”), не отражено в тексте.

Ассоциирование по синтагме (см. сх. 3):

Схема 3.

Куда?

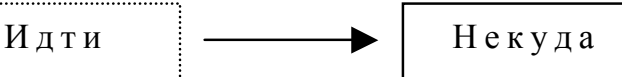

- находит себе место в тексте. В тексте оказываются зафиксированными начальная и конечная «клетки», на которых «стоял конь», и не зафиксирована та, которую он прошел. Таким образом, при поверхностно аномальном употреблении прослеживаются глубинно узуальные ассоциативные ходы.

Кажется, что этот смысл можно было бы выразить и поверхностно узуально. Например, «Жить незачем» (и так же экономно), но при этом, 
кроме бесцельности и безысходности, появляется смысл «не стоит», который вынуждает к крайним действиям. Полученное таким образом высказывание (жить незачем) логичнее было бы закончить:

...вот и

кончаешь жизнь самоубийством;

пускаешься во все тяжкие;

прожигаешь жизнь и т. п.

Другие, не столь экономные варианты:

У меня нет цели в жизни;

Я не вижу смысла в жизни;

Я не нашел смысла в жизни

- допускают реакцию: не использовал все возможности; быть может, есть шанс. В случае «жить некуда» - все варианты, известные субъекту, рассмотрены и отвергнуты. Герой не на распутье, перед тяжелым выбором, а в каком-то месте, где вообще нет дорог (Россия...). Ощущение неподвижности, «будто темная стена предстала в упор перед его ощущающим умом». Он еще чего-то ждет. Ожидание - одна из метафор жизни («В ожидании Годо» С. Бэккет). Он ждет, думает, в то время как вокруг звучат бравурные марши, аккомпанирующие девизам «Время, вперед!», «Пятилетку в 3 года!», «Даешь что-нибудь!», например: Днепрогэс, т. е. все вокруг стремятся «как можно внезапнее выполнить план», имитируя ускоряющееся движение вперед. Платоновский герой задумчиво стоит посреди углубляющегося котлована для общепролетарского дома (могилы, об этой ассоциации-метафоре ниже). Какие мысли могут приходить ему в голову? Их можно найти в платоновском тексте, и они кажутся очень уместными в этой ситуации, например:

«Может быть, легче выдумать смысл жизни в голове, может быть, можно коснуться смысла печально текущим чувством, нечаянно догадаться о нем».

«Лучше я буду думать без работы, все равно весь свет не разроешь до дна».

Второй смысловой ход конем (см. сх. 4).

В данном случае невысказанные мысли человек может собирать, копить, только в голову - единственно возможный вариант копилки для такого случая. То есть мысль родилась в голове и там же осталась. В какой форме эта мысль присутствует в голове героя? На уровне внутренней речи - свернутая, предикативная, практически не вербализованная? Или уже вербализованная и даже слабо артикулированная, про себя? Так или иначе она будет жить, пока герой ее помнит. Ее ждет смерть там же, где она родилась, т. е. смерть в утробе. Возможно, самая загадочная из смертей. Она произойдет, когда герой забудет мысль. 
Думать в голову - это даже не писать в стол («Рукописи не горят»): трагизм усугубляется большей безнадежностью сообщения и общения.

Схема 4.

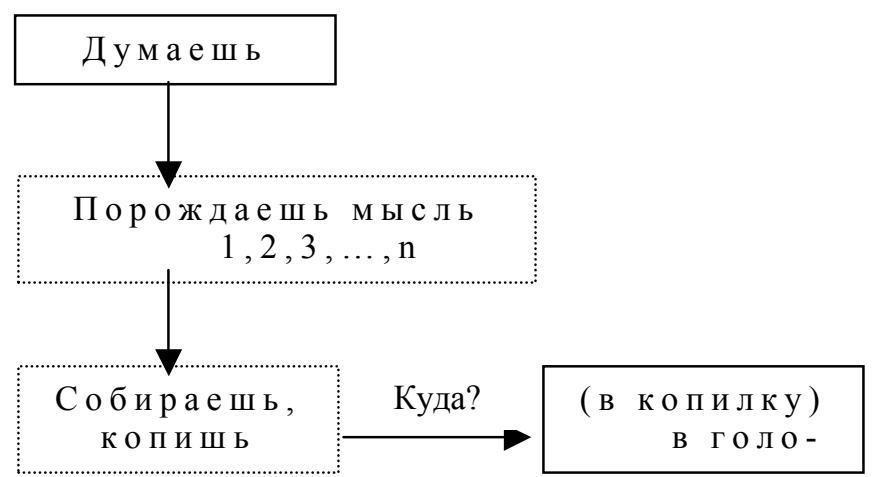

В качестве поверхностно узуальных синонимичных продолжений высказывания можно было предложить, например, следующие:

...вот и думаешь;

...вот и стоишь в раздумье.

В этом случае вероятно, что герой рано или поздно может поделиться с кем-то результатом своих размышлений. Тогда утрачивается смысл закрытой копилки мыслей, невозможности не только завершения, но даже начала коммуникативного акта, т. к. отсутствует не только слушатель, но и говорящий, а есть одиночество и «несльшнные мысли».

Мысль - еще одна метафора жизни («Cogito ergo sum» - «Мыслю, значит, существую»). Возможно, что для Андрея Платонова эта метафора не является средством усмотрения смысла жизни (метафора - средство усмотрения смысла, по Э. Гуссерлю). «Я здесь не существую, я только думаю здесь». Для Платонова «думать» - не значит «жить». Жизнь, по Платонову, - это движение, а здесь остановка, тупик; пространство переходит в Хронос, время. Время, как и мысль, понятие психическое, не пространственное (по А. Бергсону). Ожидание - тоже время. Очевидно, такие способы осмысления жизни, как мысль и ожидание, для Андрея Платонова не работают («часы терпеливо шли силой тяжести мертвого груза»). Г. Зиммель считает: «Время - есть жизнь, если оставить в стороне ее содержание». Очевидно, именно этого: оставить в стороне содержание жизни - Андрей Платонов и не хочет. А что же он хочет? «Он узнал желание жить в эту разгороженную даль». «Разгороженная даль» - пространство, предлог «в» + винительный падеж - движение куда?

Собственно говоря, этого («жить в разгороженную даль», а дальто пока загорожена) хочет персонаж Андрея Платонова, а не автор, однако уже не раз отмечалось, что реплики многих героев Андрея Платонова представляют собой части монолога автора. Время, по Платоно- 
ву, принадлежит жизни, но не равно ей. Можно «проживать время жизни», «беречь время жизни», как «время трудности» и «время тос$\kappa u »$.

В этом кратком высказывании: «Жить некуда, вот и думаешь в голову» - содержатся три метафоры жизни (дорога, ожидание, мысль). Две последние, очевидно, не релевантны для Андрея Платонова, однако они общеизвестны. Из этих метафор первая перечеркнута (некуда); сфера действия последней крайне ограничена (отсутствие коммуникации, фиксации и, наконец, «смерть в утробе»). Остается ожидание. Чего? Того времени, когда будет построен общепролетарский дом и все будут «хорониться в нем от невзгоды»" и «безмолвно существовать», «скучное место, куда можно и не стремиться», по мнению Прушевского, куда «пойдут на вечное счастливое поселение трудящиеся всей земли», и «будущиий человек найдет себе покой в этом доме». Очевидными кажутся ассоциации с тюрьмой и гробом. Об одном из своих героев Платонов говорит: домов».

"...он еще верил в наступление жизни после постройки больших

Стало быть, сам Платонов уже не верил.

Итак, в реальной окружающей жизни оказывается невозможным осуществить желание «жить в эту разгороженную даль». Реальная жизнь - это тюрьма, плен, и если движение, то к могиле.

Человек определяет себя как «заочно живущций».

Применив прием «смысловой ход конем», мы увидим следующее (см. сх. 5).

Коммуникативный фрагмент «заочно приговорен» мы воспринимаем как единицу из цитатного языкового фонда, единицу языкового опыта. При этом смысл данного фрагмента платоновского текста интерпретируется следующим образом: в отсутствие заинтересованного лица некто приговорил его родиться (быть живущим).

Правомерность представленных ассоциативных ходов подтверждается следующим высказыванием:

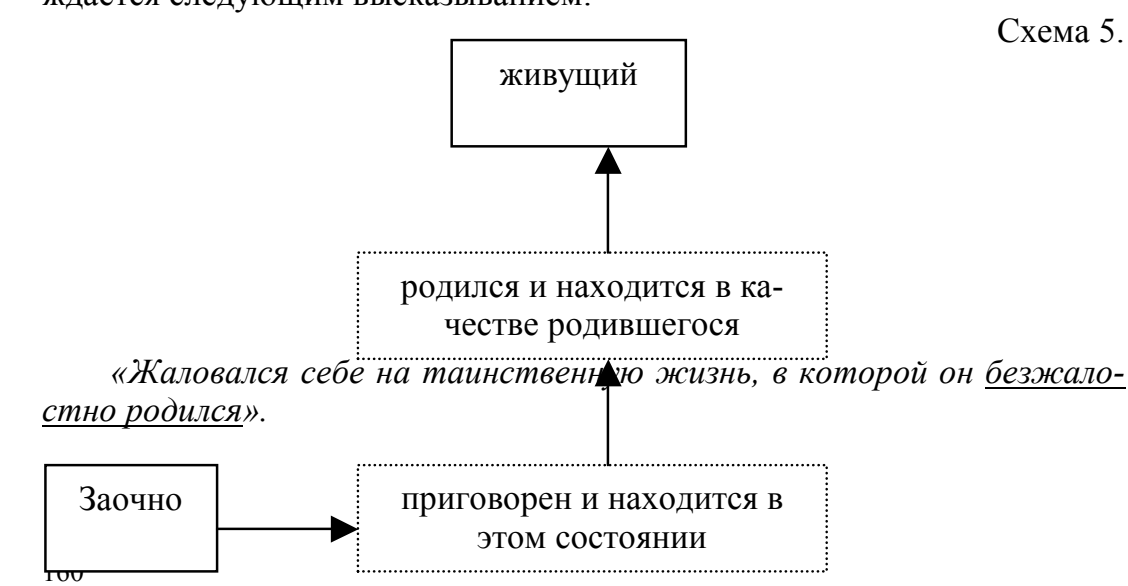

Схема 5. 
«Смысловой ход конем» выглядит следующим образом (см. сх. 6):

Схема 6.

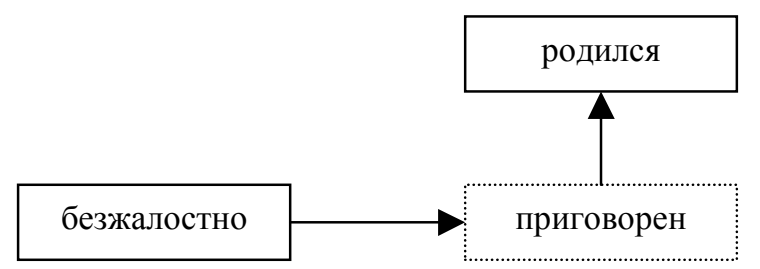

Языковая память немедленно предоставляет в наше распоряжение некий «осколок» анонимного текста, синтагму, речевой блок, речевой образец (несть числа наименованиям) и укрепляет в правильности выбранного ассоциативного хода.

Метафора жизни-тюрьмы предполагает не только приговор, но и срок:

«Живи, пока родился».

Есть две самые важные даты в жизни человека, обычно мы их видим на надгробной плите (когда родился - когда умер). В приведенном высказывании императивно дается срок («живи»), неопределенный срок, который должен длиться, пока есть только одна дата (когда родился) и не наступила другая (когда умер).

В тюрьме обычно завидуют тому, у кого меньше срок:

«Лучше б я комаром родился, у него судьба быстротечна».

Быстро проходит, протекает, потому что короткая жизнь. Его судьба, так Рок судил (приговор) - иметь короткий срок. Это предмет зависти.

Не все так печально, есть и светлая сторона жизни:

«Скучно собаке, она живет благодаря одному рождению, как и я».

Казалось бы, что же тут хорошего, если рождение - это приговор, да и живет он как собака. Однако есть слово «благодаря», благодаря которому есть возможность в негативном разглядеть позитивное. Сравним:

«Его знал один только Козлов, благодаря своим прошльмм конфликтам».

Аномальное употребление слова «благодаря» позволяет даже в конфликте обнаружить нечто позитивное, иначе не иметь бы Козлову такого уникального знания. «Благодаря» настраивает на поиск позитивного, и мы его находим даже там, где не ожидаем.

Возвращаясь к феномену жизни, постараемся и там обнаружить нечто позитивное. Так мы вспоминаем, что есть не только «общяая грусть жизни», но и «летний вишневый вечер», и "равнодушие ясной мысли, близкой к наслаждению», а также «время чувственной жизни и видимо- 
сти счастья», и способность «заволноваться от дружбыл». Конечно, этот позитивный ряд далеко не исчерпан.

А между тем герои Андрея Платонова легко «решают скончаться» «со счастьем равнодушия к жизни», даже не задумываясь над разрешением альтернативы «быть или не быть?».

Рассматривается только один вариант: «Либо мне погибнуть?» $\mathrm{Pe}-$ шающим аргументом при этом является: «Мною все пользуются, но мне никто не рад».

Есть и уникальный платоновский вариант самоубийства - «устраниться в тишину безвестности». В тишине безвестности находятся камешки, «отсохшие листья», «ничтожный песок», «прах» и другое подобное. Человек чувствует себя родственным этим «предметам забвения», он ощущает себя как камень или даже камешек. Он мертв при жизни. Вспоминается миф о Медузе Горгоне: человек смотрит на окружающую жизнь и - каменеет.

Перпендикулярно линии «Время, вперед!» идет (с направлением вниз) линия углубления котлована. («Земля поражена ямами», - котлован не один) (см. сх. 7).

Котлован - общепролетарская могила, в которую землекопы отдают свою «излишнюю теплоту» («Люди наполнены той излишней теплотой, которая названа однажды душой»).

Схема 7.

«Время, вперед!»

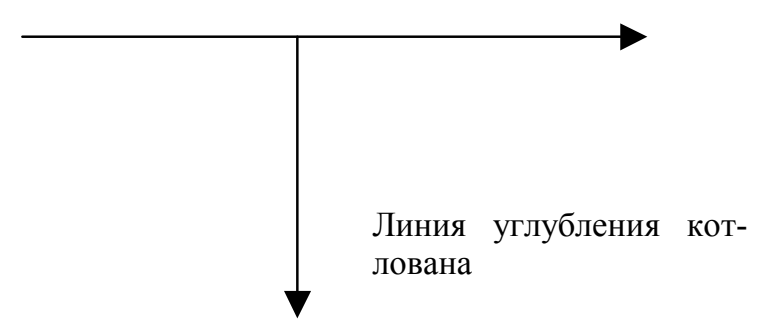

Предположение о наличии в человеке «излишней теплоты» не мешает Ю.И. Левину выдвинуть предположение о том, что «жизнь» у Андрея Платонова «как работа завода». Я бы конкретизировала: не жизнь вообще, а живой человек как работающий завод (даже во время сна).

«Каждое ли производство дает добавочным продуктом душу человека?»

«А если прочзводство улучшить до точной экономии, то будут ли происходить из него косвенные, нежданные продукты?»

«....иора питаться для дневного труда». 
Они жили «отдельно от природы, в светлом месте электричестBa».

«...nо толщине жил было видно, как много крови они должны пропускать во время напряженного труда».

«...все тело шумело в питающей работе сна».

И даже «излишняя теплота» здесь уместна, как энергия для производства, если забыть, что это душа.

Когда тело напитается для труда, начинается сам труд, который, по Андрею Платонову, состоит в передаче этого «излишнего тепла» мертвому телу мира (мир - «мертвое тело»).

«Обращал всю жизнь своего тела в удары по мертвым местам».

«...мог пожертвовать на труд все свое тело».

"... пот слабости капал в глину».

«Он не помнил времени и места, спуская остаток своей теплой сильь в камень, камень нагревался, а Козлов постепенно холодел... ожидая, что кости прорвут непрочную кожу».

"...жизнь уходит как течение дыхания». сти»?..

И удастся ли «перед смертью не заплакать от тоски тщчетно-

Думается, что для Андрея Платонова не было бы инородным использование формулы, выражающей отношение жизни и смерти, ведь он науку называл «насущңная наука» (см. сх. 8).

Схема 8.

Отношение жизни и смерти

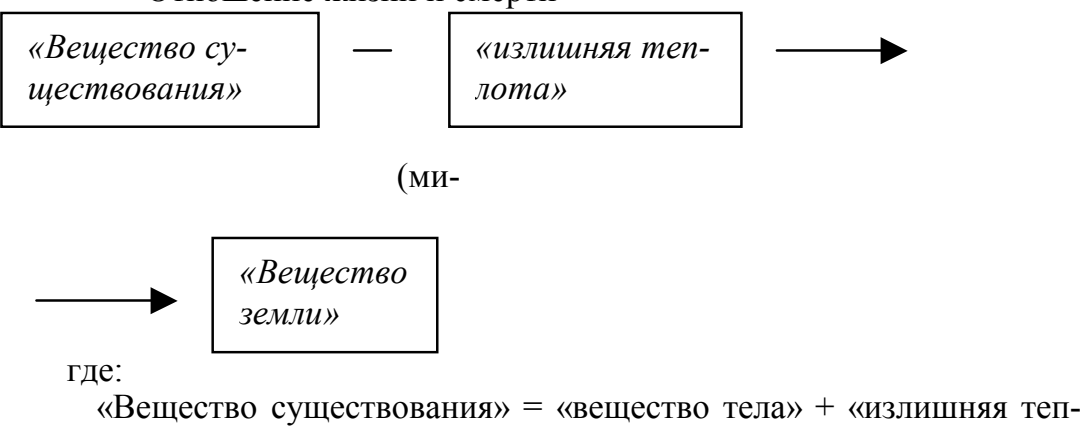
лота»

«излишняя теплота» - душа

«вещество земли» = «прах» + «всякая безвестность»<smiles>[CH]CC</smiles>

Трансформируется из «вещества тела» 
Эта реакция необратима («безвозвратная смерть»). Андрей Платонов семантизирует смерть как «смирение в земле», превращение в «ничтожный песок» («замертво лежал ничтожный песок»). Он стал «ничто», а был - человек. Несмотря на то, что землекопы Андрея Платонова «привыкли работать», «каждый из них придумал себе идею будущего спасения отсюда».

Необходимо замечание о том, что построение фразы по формуле $\mathrm{AB}+\mathrm{BC}+\mathrm{CD}=\mathrm{ABCD}$, которое будет продемонстрировано на приведенном высказывании из Андрея Платонова, почерпнуто из исследований Б. Гаспарова. Б. Гаспаров анализирует язык как динамическую систему, основываясь на деятельностном подходе к описанию языка (Ю. Н. Караулов, А. А. Залевская), а также на подходе Л. С. Выготского («речь ребенка строится на основе конкретных образцов»), на мнении Р. Барта о «возможности построения языка синтагм» (у Ю. Н. Караулова - и языка парадигм), на анализе языка как мнемонической среды, на том основании, что в речи существуют речевые блоки, которые мы помним и немедленно узнаем, а «смысл создается при взаимодействии с другими словами».

Представив последнюю фразу из Андрея Платонова как куски «предыдущего языкового опыта», связанные по формуле Б. Гаспарова, мы получим:

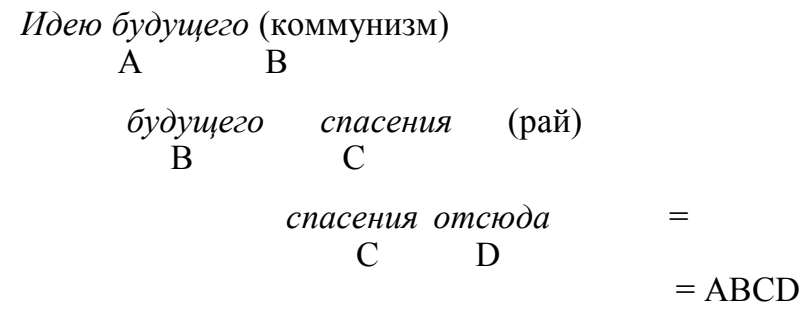

Фрагмент CD спасения отсюда, будучи подвергнутыми анализу с использованием приема «смысловой ход конем» может быть представлен следующим образом (см. сх. 9):

Схема 9.

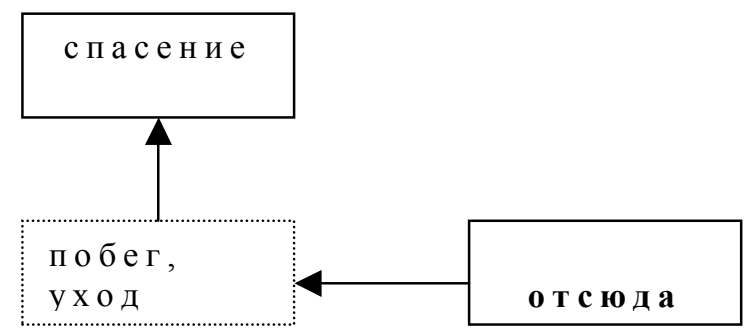


Таким образом, высказывание на ассоциативном уровне выглядит следующим образом (см. сх. 10):

Можн м м у н и з м сказать, что понятия «коммунизм», «раи»», «побег» оказываются у Андрея Платонова контекстуальными синонимами, т. к. все они - варианты спасения.

Коммунизм - это "будущее неподвижное счастье и детство». Движение к нему мыслится как движение вперед, а там - неподвижность: «от счастья только стыл начнется». А дети? «Он же (ребенок) весь свет родился окончить». Дети - конец света. Дети - время. У Андрея Платонова можно «проживать время жизни», но если нет движения, нет жизни, есть только время («мертвый груз»).

«Идея Рая есть логический конец человеческой мысли в том отношении, что дальше она, мысль, не идет, ибо за Раем больше ничего нет, ничего не происходит. И поэтому можно сказать, что Рай - тупик, это последнее видение пространства... с которого прыгнуть некуда, только в Хронос - в связи с чем и вводится понятие вечной жизни» (цитата из И. Бродского). Рай в православной традиции - это блаженство в единении с Богом. Движение туда мыслится как движение вверх, но там движения нет.

По Андрею Платонову, это не вечная жизнь, а вечный плен, возможно, пленительный.

У Андрея Платонова религиозно-коммунистические параллели не случайны, ведь его строители и землекопы «добывают себе жизнь под золотыми головами храмов и вождей». В ортодоксальной России, в православной России уйти от вековых традиций практически невозможно. «Ты его хочешь от бога отучить, а он тебе Собор Революции nостроит». В религиозной традиции больше притягательного потому, что есть Кого любить.

Строители и землекопы Андрея Платонова понимают, что «наслаждаться как-то еще рано», нужны терпение и надежда (у некоторых есть вера: «счастье наступит исторически»).

Надежда на коммунизм и вера в него должны смениться, по Андрею Платонову, на «стыл» и «безмолвие».

Смысловой анализ текстов Андрея Платонова (отчасти с использованием приема «смысловой ход конем») позволяет сделать следующие выводы:

во-первых, жизнь, не «вписанная в устроенный ужас системы», это движение, категория пространственная (не время; не мысль; не ожидание); 
во-вторых, реальная жизнь мыслится как тюрьма (отсутствие движения, тупик); если и можно говорить о движении, то это движение к могиле;

6-третьих, с такой жизнью легко расстаться (самоубийство, «устранение в тишину безвестности»-смерть при жизни);

в-четвертых, выход, провозглашаемый в виде цели - коммунизм, не спасает и не кажется выходом, т. к. это не только тупик, «стыд», «безмолвие», но и конец света, апокалипсис;

6-nяmblx, идея Рая, которая прочитывается в глубинных структурах текста, осмысливается как будущее спасение «бесцельных мучеников» Андрея Платонова;

в-шестых, живое и неживое сближаются (человек - завод);

в-седьмых, смерть, «смирение в земле», переход «вещества существования» в «вещество земли» происходит при утрате «излишней теплоты» (души) «во время труда»;

в-восbмых, есть в жизни и что-то позитивное.

И, наконец, последнее замечание.

Смысловой прием в работе по восприятию текста, представленный в данной статье («смысловой ход конем»), - не претендует на использование в широких кругах читательской аудитории. Его использование хотя бы в рамках данной работы служит симптомом того, что «линейность ослабляет свой гнет», «современное мышление становится все более нелинейным»; подтверждает слова Жака Деррида: «Мысль странствует в смысловом пространстве», поэтому задача читателя состоит в нахождении ее траектории, отталкиваясь от «следов мысли», представленных на письме.

$$
\text { Ли те ратура }
$$

1. Белянин В. П. Психолингвистика. М.: Изд-во Флинта, Московский психологосоциальный институт, 2001.

2. Бродский И. Предисловие к повести «Котлован» // Андрей Платонов. Мир Творчества. М.: Современный писатель, 1994.

3. Выготский Л. С. Мышление и речь. М.: Лабиринт, 1996.

4. Гаспаров Б. М. Язык, память, образ. Лингвистика языкового существования. М.: Новое литературное обозрение, 1996.

5. Залевская A. A. Введение в психолингвистику. М.: Российский государственный гуманитарный университет, 1999.

6. Кантор К. М. Без истины стыдно жить // Вопросы философии. 1989, № 3.

7. Караулов Ю. Н. Активная грамматика и ассоциативно-вербальная сеть. М., 1999.

8. Кобозева И. М., Лауфер Н. И. Языковые аномалии в прозе А. Платонова через призму процессов вербализации // Логический анализ языка, противоречивость и аномальность текста. М.: Наука, 1990.

9. Левин Ю. И. От синтаксиса к смыслу и далее «Котлован» А. Платонова // Избранные труды. Поэтика и семиотика. М.: Школа. Языки русской культуры. 1998.

10. Михеев M. В мир Платонова через его язык. Предположения, факты, толкования, догадки. М.: Изд-во Московского университета, 2003.

11. Подорога В. А. Евнух души // Вопросы философии. 1989, № 3.

12. Субботин М. М. Теория и практика нелинейного письма (взгляд сквозь призму «грамматологии» Ж. Деррида) // Вопросы философии 1993, № 3. 